\title{
REDEFINITION OF ZEHNERIA AND FOUR NEW RELATED GENERA (CUCURBITACEAE), WITH AN ENUMERATION OF THE AUSTRALASIAN AND PACIFIC SPECIES
}

\author{
W.J.J.O. DE WILDE \& B.E.E. DUYFJES \\ Nationaal Herbarium Nederland, Universiteit Leiden branch, P.O. Box 9514, \\ 2300 RA Leiden, The Netherlands; e-mail: dewilde@nhn.leidenuniv.nl
}

\section{SUMMARY}

\begin{abstract}
The genus Zehneria Endl. is split into 5 genera, of which 4 are new: Indomelothria, Neoachmandra, Scopella, and Urceodiscus. Apart from several new combinations and taxa of subspecific rank, the following species are described as new: I. chlorocarpa, N. backeri, N. lancifolia, N. macrantha, $N$. nesophila, N.platysperma, U. arfakensis, U. carrii, U. hippocrepicus, U. parviflora, U. scabridula, U. viridis, Z. elbertii, Z. erythrobacca, Z. immarginata, Z. neocaledonica, Z. pedicellata, Z. pisifera, $Z$. tahitensis, and Z. trullifolia. The New World genus Melothria was introduced in Asia where it is represented by one species, $M$. pendula $\mathrm{L}$.
\end{abstract}

Key words: Cucurbitaceae, Zehneria, SE Asia, new genera.

\section{INTRODUCTION}

Since the monographic treatments of Cucurbitaceae by Cogniaux $(1881,1916)$, the genus Melothria L. was considered to be wide-ranging, containing many species from the Old and the New World, including many Asian species. With the re-establishment of Mukia Arn. and Solena Lour. to generic rank and the decision that the genus Melothria can best be applied for American species only (Jeffrey, 1962, 1969, 1979), the remaining plants from the Old World named until then under Melothria were transferred to Zehneria (Jeffrey, 1962, 1967).

Recent study of the extensive Asian herbarium material filed under Zehneria and fieldwork has made it clear that 6 genera should be recognised, among which 4 new ones. These genera are look-alikes, but comparing the flowers in detail it becomes apparent that they are all markedly different. The main differentiating characters are the place of insertion of the stamens, the number of thecae of the anthers, the shape of the anthers, the presence or absence of a disc, the presence or absence of staminodes, the shape of the stigma-lobes, and the disposition of the male flowers (Fig. 1, 2; Table 1). All are small, annual or subperennial, herbaceous or subligneous climbers, less than $5 \mathrm{~m}$ tall; tubers have not been recorded. The genus Melothria occurs in Asia only as introduced with one species, M. pendula.

The six genera here recognised are also largely confirmed by study of the pollen (Van der Ham \& Pruesapan, in prep.) and DNA-analysis (Cross et al., in prep.); the results of both studies (at Leiden) will be published in separate papers shortly. 


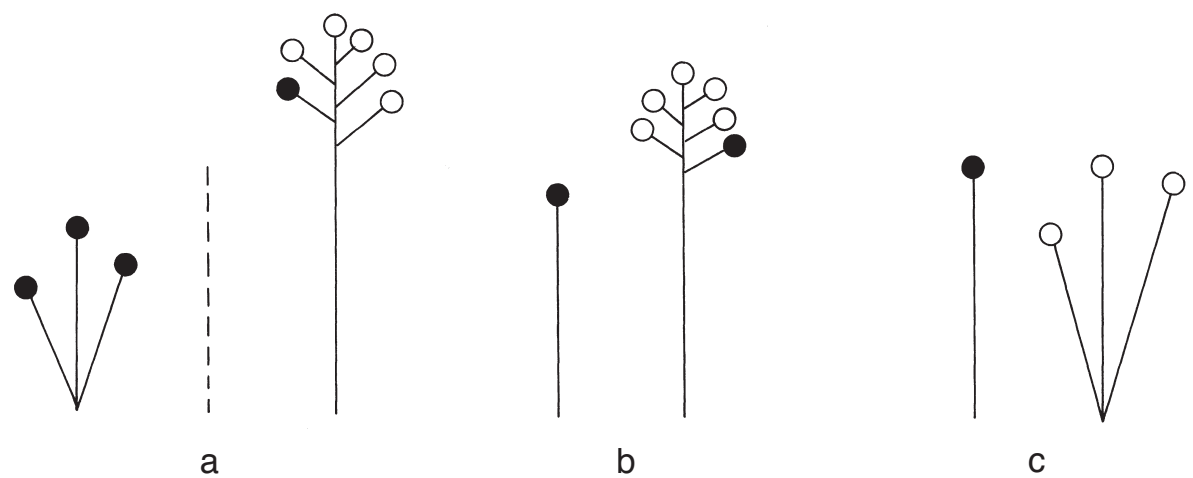

Fig. 1. Schemes of inflorescences, black dot $=$ female flower, open dot $=$ male flower. a. Zehneria (usually dioecious); b. Indomelothria, Melothria, Scopella, and Urceodiscus; c. Neoachmandra.
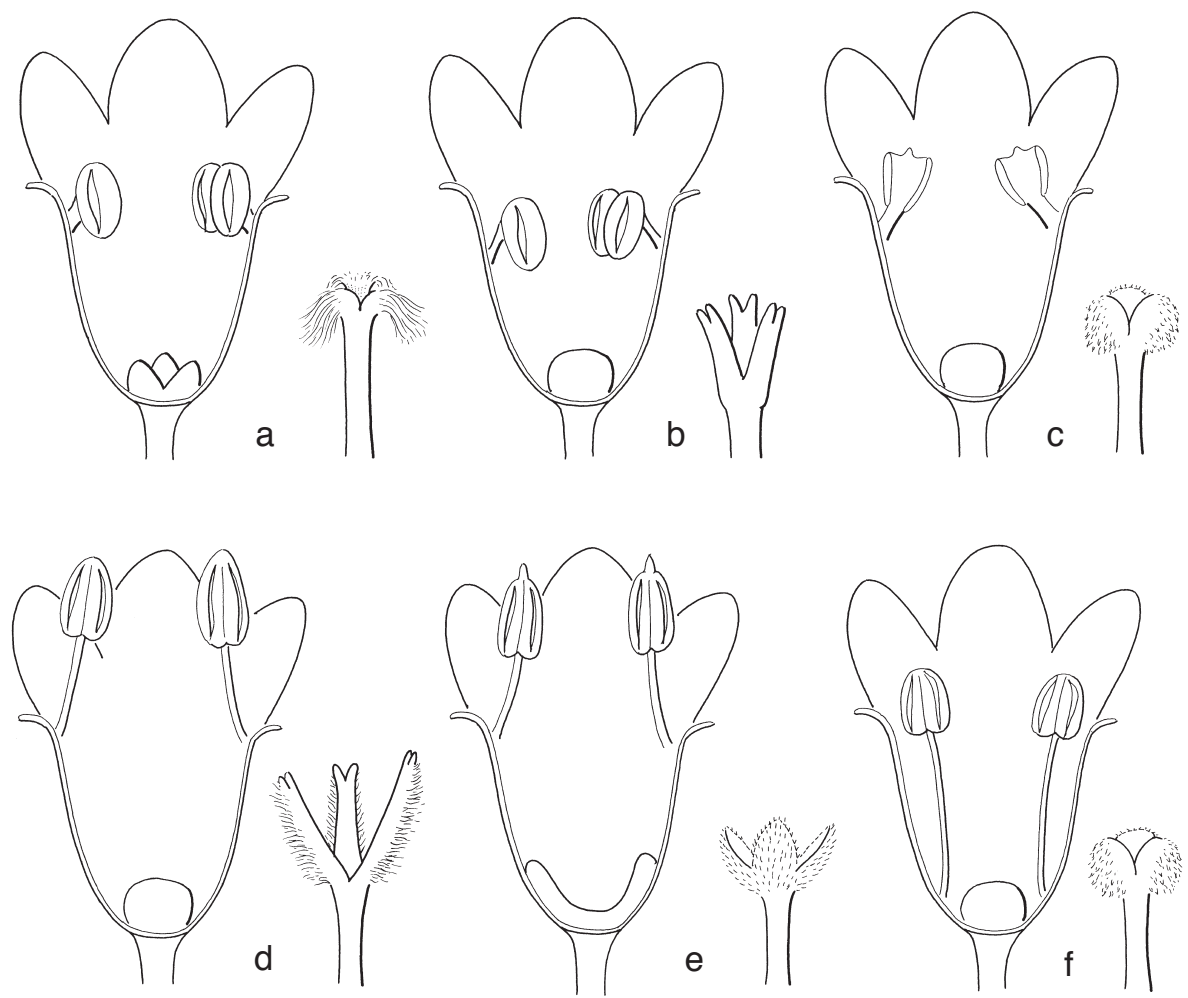

Fig. 2. Schematic longitudinal sections of male flowers each with a schematic stigma from the female flower. a. Indomelothria (2 species); b. Melothria (1 introduced species); c. Neoachmandra (23 species in Asia); d. Scopella (2 species); e. Urceodiscus (7 species); f. Zehneria (19 species in Asia). 


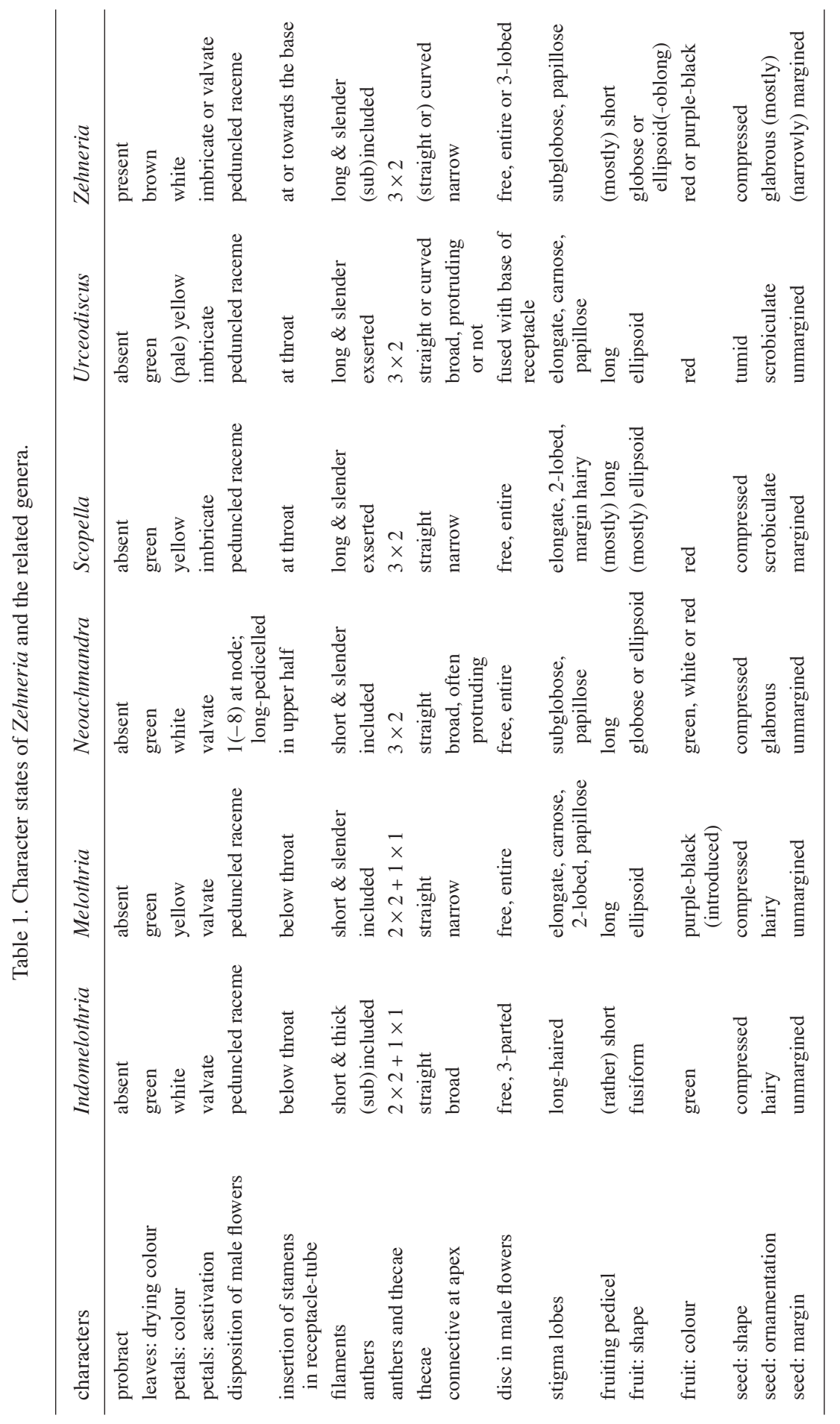


For the morphological delimitation of species and genera SE Asian material in many herbaria was studied (see acknowledgements), but as our study was aimed to the forthcoming treatments of Cucurbitaceae in Flora Malesiana and Flora of Thailand, only species occurring in these areas are fully described. Two of the larger genera at present treated - Neoachmandra and Zehneria - also occur widely in Africa and Madagascar, and species from these areas have been seen only superficially and have not been renamed. However, for comparison, flora treatments of most countries (areas) of Africa were consulted, viz. South Africa (Meeuse, 1962); Madagascar (Keraudren, 1966); Tropical East Africa (Jeffrey, 1967); Cameroun (Keraudren, 1967); Angola (R. \& A. Fernandes, 1970); Sénégal (Berhaut, 1975), Central Africa (Keraudren-Aymonin, 1975a); Zambesi River area (Jeffrey, 1978); Rwanda (Reekmans, 1983); Ethiopia and Eritrea (Jeffrey, 1995).

\section{KEY TO THE GENERA}

primarily based on male flowering specimens

1a. Stamens 3; anthers two 2-thecous, one 1-thecous. Male flowers in a peduncled

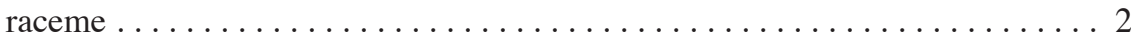

b. Stamens ( 2 or) 3 ; all anthers 2-thecous. Male flowers directly inserted at the node or in a peduncled raceme. . . . . . . . . . . . . . . . . . 3

2a. Petals yellow. Stamens inserted below the apex of the receptacle-tube. Filaments short and slender. Disc half-globose. Stigma-lobes carnose. - M. pendula, intro-

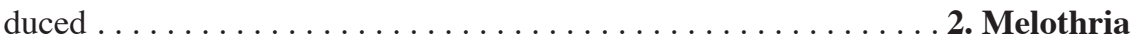

b. Petals white (but see note 1 under I. blumei). Stamens inserted in the throat of the receptacle-tube. Filaments short and thick. Disc 3-parted. Stigma-lobes with long dense threads $\ldots \ldots \ldots \ldots \ldots \ldots \ldots \ldots \ldots \ldots \ldots \ldots \ldots \ldots$. Indomelothria

3a. Male flowers single or few-fascicled, directly inserted at the node, usually co-axillary with a female flower. Petals valvate. Filaments short, as long as or shorter than the anther, thecae straight $\ldots \ldots \ldots \ldots \ldots \ldots \ldots \ldots \ldots \ldots$ 3. Neoachmandra

b. Male flowers arranged in a (short-)peduncled raceme. Filaments long, longer than the anther, thecae straight or curved $\ldots \ldots \ldots \ldots \ldots \ldots \ldots \ldots$

4a. Petals white (but see the note under Z. tahitensis), imbricate or valvate. Stamens inserted in the lower half of the receptacle-tube, (largely) included. Stigma-lobes papillose-hairy. Dry pericarp finely shallowly pitted ........ 6. Zehneria

b. Petals yellow, imbricate. Stamens inserted in the throat of the receptacle-tube, (largely) exserted. Dry pericarp smooth or finely warted ............ 5

5a. Petals pale yellow. Disc saucer-shaped, not obvious because it is adnate with the basal part of the receptacle-tube. Stigma-lobes papillose-hairy. - New Guinea

5. Urceodiscus

b. Petals bright yellow. Disc free, half-globose, at base of the receptacle-tube. Stigmalobes with fringed margin. - Widespread, SE Asia, W Malesia . . . 4. Scopella 


\title{
2. KEY TO THE GENERA
}

primarily based on fruits and seeds, applicable for SE Asia and the Pacific; not for India and Australia

1a. Seed faces ornamented, coarsely pitted or warted. . . . . . . . . . . 2

b. Seed faces smooth, glabrous or hairy, or finely shallowly warted . . . . . . . 4

2a. Fruit (sub)sessile. - A genus not treated here, but liable to be confused. . . . . . .

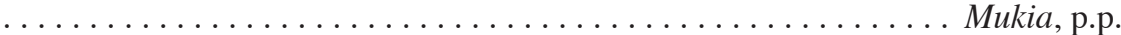

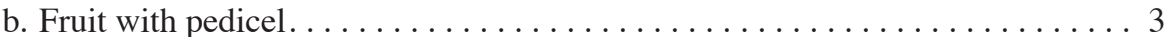

3a. Seeds flattened, margined. - Not in E Malesia . . . . . . . . . . 4. Scopella

b. Seeds subglobose, unmargined. - New Guinea. . . . . . . . . . 5. Urceodiscus

4a. Seeds (narrowly) margined (not obvious in Z. immarginata and in hairy seeds of

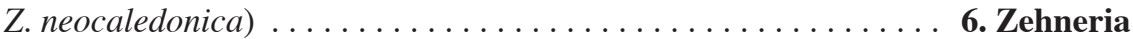

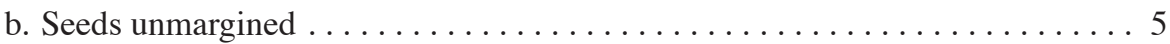

5a. Seeds glabrous, sometimes short-winged. [Male flowers long-pedicelled, inserted at the node. $\ldots \ldots \ldots \ldots \ldots \ldots \ldots \ldots \ldots \ldots \ldots \ldots \ldots \ldots \ldots$ 3. Neoachmandra

b. Seeds hairy, unwinged. [Male flowers in a peduncled raceme.] . . . . . . . 6

6a. Fruit ellipsoid, juicy, purple-black. - Introduced . . . . . . . . . Melothria

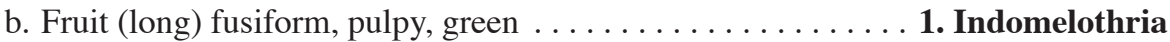

1. INDOMELOTHRIA - Fig. 1b, 2a; Table 1

Indomelothria W.J. de Wilde \& Duyfjes, gen. nov.

\begin{abstract}
A Zehneria in probractea absenti differt; folia viridia in sicco; stamina supra tubi receptaculi faucem inserta; filamenta brevia crassa, antherae duae 2-thecis, una 1-theca, connectivum latum; discus 3-partitus; stigmatis lobi longe pubescentes; fructus fusiformis; semina pubescentia sine margine. - Typus: Indomelothria chlorocarpa W.J. de Wilde \& Duyfjes.
\end{abstract}

Climbers 1-5 m long, (sub)perennial; monoecious; green on drying. Probract absent. Tendrils simple. Leaves simple, entire or shortly hastately lobed, subpinninerved to palminerved. Flowers small, 5(-10) mm diam., white; sepals minute, linear or subulate, \pm patent; petals free, obovate-elliptic, valvate in bud; receptacle-tube campanulate or urceolate. Male inflorescence: a slender peduncled raceme, the flowers lax, sometimes co-axillary with 1 female flower. Bracts absent. Male flowers: pedicel 2-12 mm long, slender, persistent; sepals with adaxially a short spur (not seen in I. blumei); stamens 3 , inserted in or close to the throat of the receptacle-tube, filaments short, thick, shorter than the anther, anthers two 2-thecous, one 1-thecous, (sub)included, thecae halflateral, straight or slightly curved, connective broad, not produced; disc free, at apex \pm 3 -parted. Female flowers solitary or co-axillary with male raceme; pedicel short; ovary narrowly ellipsoid, \pm with slender neck, glabrous; stigma consisting of 3 short arms, each arm ending in numerous, long, thread-like appendages; staminodes absent; disc a faintly 3-lobed annulus, largely free from the receptacle-tube. Fruit 1 , with short fruiting pedicel, narrowly ellipsoid, fusiform, rather large, 5-7 cm long, glabrous, green, pulpy; dry pericarp membranous-cartilaginous, smooth. Seeds numerous (see note 1), compressed, ovate-elliptic, faces little convex, not sculptured, but with dense appressed hairs (see note 2), margin absent, unwinged. 
A genus of 2 species extending from $\mathrm{S}$ Myanmar and $\mathrm{S}$ Thailand to W Malesia (Sumatra, Java, Borneo). Not known from Peninsular Malaysia and Philippines.

Notes -1 . The seeds are absent from the base and apical part of the fruit, resulting in its fusiform, beaked shape.

2. The hairy surface of the mature seeds is formed of elongate lengthwise directed glassy cells, which become largely free but remain attached at one side. Similar hairy seeds are found in Melothria pendula (America and introduced in Asia) and in Zehneria neocaledonica (New Caledonia).

\section{KEY TO THE SPECIES OF INDOMELOTHRIA}

1a. Leaves generally elliptic, usually two times longer than wide, or even longer. Male perianth c. $4 \mathrm{~mm}$ diam., sepals without (?) an appendage. Fruit $4(-5) \mathrm{cm}$ long; seeds $2.5-4 \mathrm{~mm}$ long. - Widespread; lowlands . . . . . . . . 1. I. blumei

b. Leaves \pm ovate. Male perianth c. $6 \mathrm{~mm}$ diam., sepals with an adaxial appendage. Fruit 4-8 cm long; seeds c. $8 \mathrm{~mm}$ long. - Lowlands or mountains; two subspecies, each with a restricted area $\ldots \ldots \ldots \ldots \ldots \ldots \ldots \ldots$. I. chlorocarpa

1. Indomelothria blumei (Ser.) W.J. de Wilde \& Duyfjes, comb. nov.

Bryonia blumei Ser. (1828) 305. - Bryonia heterophylla Blume (1826) 925, non (Lour.) Raeusch. (1797) 282; non (Lour.) Steud. (1821) 123; (1841) 232 (= Solena heterophylla Lour. (1790) 514).

- Melothria marginata (Blume) Cogn. var. $\beta$ heterophylla (Blume) Cogn. (1881) 594, p.p.; (1916) 93, p.p. - Type: Blume s.n., barcode L0129721 (holo L), Java, Batavia ('inter frutices juxta Bataviam').

Rhynchocarpa ?deltoidea Kurz (1877) 105. - Lectotype (here chosen): Kurz 1889 (holo K, 2 sheets, both sterile), Myanmar, Pegu.

Subperennial (?) climber, 1-3 m long; stem glabrescent, 1(-2) mm thick. Tendrils glabrous. Leaves: blade (ovate-)elliptic to narrowly elliptic or long-triangular, 4-8 by 1-4 cm, base subtruncate or shallowly or deeply cordate, occasionally short-hastate, margin entire or shallowly sparsely dentate, teeth to $4 \mathrm{~mm}$ long, both surfaces scabrous (cystoliths often inconspicuous), but nerves shortly rough-hairy; petiole 1-2 cm long, rough-hairy. Male inflorescences finely scabrous or subglabrous, peduncle slender, 1-2 $\mathrm{cm}$ long, raceme $0.1-0.5(-1.5) \mathrm{cm}$ long, with few or up to 10 flowers. Male flowers (incompletely known, mainly from 1 open flower in Kerr 3735): pedicel (0.5-)1-2 $\mathrm{mm}$ long; corolla 4-5 mm diam.; receptacle-tube campanulate, 1.5-2 $\mathrm{mm}$ long and wide, inside curly hairy in upper half, hairs $0.5 \mathrm{~mm}$ long or less; sepals $1 \mathrm{~mm}$ long, with sparse minute hairs or glabrous, adaxial appendage not apparent; petals ovate, 2 by $1.5 \mathrm{~mm}$, (sub)obtuse, on both sides (papillose) hairy; filaments $0.5 \mathrm{~mm}$ long, anthers subcircular in outline, $1 \mathrm{~mm}$ diam., thecae curved, connective with few minute hairs; disc subglobose, $1 \mathrm{~mm}$ diam., irregularly lobed. Female flowers not seen. Fruit solitary or co-axillary with male raceme, $4(-5)$ by $1-1.5 \mathrm{~cm}$, colour not known; fruiting pedicel $0.3-0.5(-1) \mathrm{cm}$ long. Seeds greyish brown, $2.5-4$ by $2-2.5$ by $1 \mathrm{~mm}$.

Distribution - Widespread but rarely collected: Myanmar (known only from Kurz 1889, Pegu); Thailand (Bangkok and environs); Indonesia: Sumatra, E Kalimantan, W Java. 
Habitat \& Ecology - Forest edges, scrub, open marshy forest, marshland, in garden hedge (Bangkok); at sea level to $300 \mathrm{~m}$ altitude; flowering and fruiting May to July and November.

Notes -1 . Kerr 3735 recorded flowers as yellow, but possibly this pertains to the comparatively large yellow anthers. Also Lörzing 3385 (Sumatra) recorded the flowers as yellow. More material and field study is needed. The observation of the flower colour, regarded as an important genus character, should get special attention. The petals in I. chlorocarpa are white.

2. This widespread species is apparently easily overlooked as no recent collections are known; the latest are of 1925 (Endert 2080, E Kalimantan) and of 1926 (Collins 1357, Thailand). The details of male and female flowers are still not known.

2. Indomelothria chlorocarpa W.J. de Wilde \& Duyfjes, spec. nov. - Fig. 3

Scandens 2-5 m longa. Folia integra ovata basi rotundata vel vadose cordata; fructus 4-8 cm longus; semina c. $8 \mathrm{~mm}$ longa. - Typus: W.J. de Wilde, Postar, Tajuddin \& Good SAN 143915 (holo L; iso SAN), Sabah, Imbak River area.

Subperennial climber, 2-5 m long, glabrescent (hairs c. $0.1 \mathrm{~mm}$ long); stem 1-2(-5) mm thick. Tendrils glabrous or somewhat harshly hairy. Leaves: blade entire or occasionally hastately lobed, subcircular, ovate(-elliptic) or elongate-triangular in outline, $5-12$ by $4-8 \mathrm{~cm}$, base broadly rounded or shallowly truncate-cordate, margin entire or sparsely shallowly dentate, both surfaces glabrous but scabrous, except for sparse-hairy nerves, cystoliths sometimes apparent; petiole 1.5-4 cm long, (scabrous-)hairy, hairs to $1 \mathrm{~mm}$ long. Male inflorescences glabrescent; peduncle slender, 1-2 cm long, 0.2 $\mathrm{mm}$ thick; raceme (0.2-)0.5-3 cm long, 3-25-flowered. Male flowers: pedicel 2-10 mm long; perianth 5-8 mm diam.; receptacle-tube urceolate, $3.5-4.5$ by $2.5-3.5 \mathrm{~mm}$, outside glabrous, inside with a broad band of dense, c. $1 \mathrm{~mm}$ long hairs, $1.5-2 \mathrm{~mm}$ below the throat; sepals $(0.5-) 1 \mathrm{~mm}$ long, glabrous, with adaxially a short spur (Fig. $3 \mathrm{~d}, \mathrm{~g}, \mathrm{k}$ ); petals (ob)ovate-elliptic, $3-4$ by $(2-) 2.5-3 \mathrm{~mm}$, blunt or rounded, papillose (gland-)hairy, creamy-white, \pm recurved at anthesis and exposing anthers; filaments c. $0.5 \mathrm{~mm}$ long, thickish, anthers broad-ellipsoid or subcircular, 1.2-1.5 mm diam., orange, contrasting with the white corolla, thecae short-ellipsoid, \pm curved, sublateral with broad connective (Fig. 3d, e); disc subglobose, c. $1.5 \mathrm{~mm}$ diam., 3-parted in the upper third. Female flowers: pedicel 2-10 mm long; ovary long-fusiform, glabrous, $10(-15)$ by $2.5 \mathrm{~mm}$, at apex \pm narrowed into a neck $2-3 \mathrm{~mm}$ long; perianth as in male flower but larger, 10-12 mm diam., inside faintly hairy; style c. $4 \mathrm{~mm}$ long, glabrous, stigma c. $3 \mathrm{~mm}$ diam., consisting of 3 thick lobes densely set with slack (pendent) hairs 1-1.5 mm long; staminodes absent; disc a depressed ring-shaped cushion, c. 1 by 2.5 mm. Fruit (4-) $5-8$ by $1-1.5 \mathrm{~cm}$; pulp greenish white; fruiting pedicel $0.4-1.5 \mathrm{~cm}$ long. Seeds $7-8$ by 4 by $1.5 \mathrm{~mm}$.

Field-notes - Flowers creamy-white, anthers orange. Fruits dark green, paler striped, smelling of cucumber. The flowers sometimes develop from short shoots on the older wood, in shady environment, close to the ground.

Distribution - Two subspecies: one in Borneo (Sabah and NE Kalimantan) and one in W Java. 


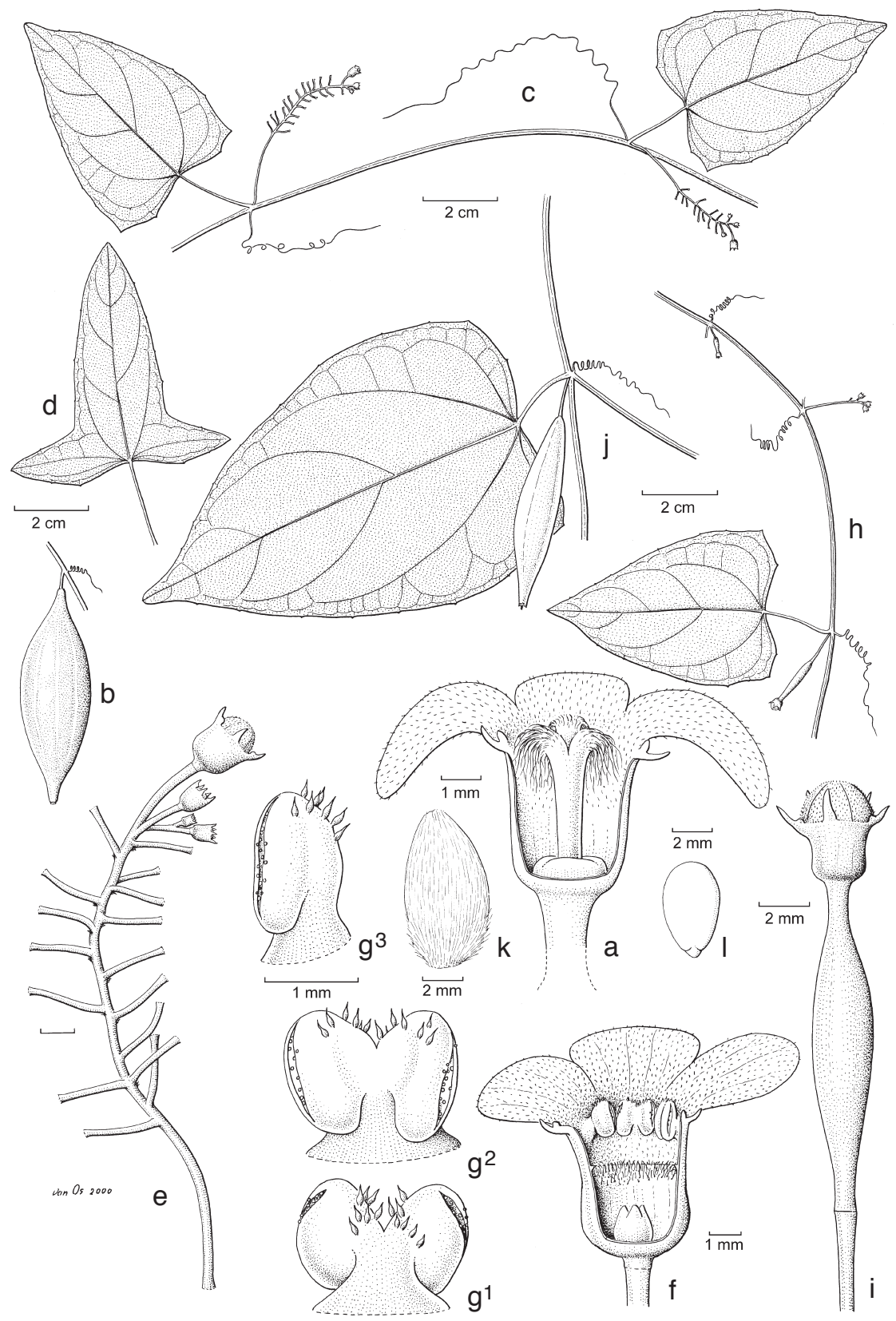

Fig. 3. a, b: Indomelothria chlorocarpa W.J. de Wilde \& Duyfjes subsp. chlorocarpa. a. Female flower, opened; b. fruit. - c-l: Indomelothria chlorocarpa W.J. de Wilde \& Duyfjes subsp. halimunensis W.J. de Wilde \& Duyfjes. c. Portion of male branch; d. leaf; e. male inflorescence; f. male flower, opened; $g^{1}, g^{2}, g^{3}$. stamens; h. portion of female branch; i. female flower bud; j. node with fruit; k. seed; 1. embryo (a: SAN 141909; b: SAN 143729; c, e-g: De Wilde 21876; d: De Wilde 21877; h-j: De Wilde \& Duyfjes 21927 (type); k, l: De Wilde 21875). 


\section{KEY TO THE SUBSPECIES}

1a. Male pedicels 2-4 mm long. Male disc with rounded lobes. - NE Borneo ..... $\ldots \ldots \ldots \ldots \ldots \ldots \ldots \ldots \ldots \ldots \ldots \ldots \ldots \ldots \ldots \ldots \ldots$ a. subsp. chlorocarpa

b. Male pedicels 5-10 mm long. Male disc with subacute lobes. - W Java (Halimun Mts $\ldots \ldots \ldots \ldots \ldots \ldots \ldots \ldots \ldots \ldots$ b. subsp. halimunensis

a. subsp. chlorocarpa - Fig. 3a, b; Plate 3a, b

Male pedicels 2-4 mm long; male disc with broadly rounded lobes. Fruiting pedicel $0.5(-1) \mathrm{cm}$ long.

Distribution - Borneo: Sabah, NE Kalimantan.

Habitat \& Ecology - Shaded in (disturbed) primary forest and forest edges; recorded from limestone and brown loamy soil; at altitudes from sea level to $1000 \mathrm{~m}$; flowering and fruiting mainly from July to January.

Specimens examined:

Sabah: J. \& M.S. Clemens 26878; De Wilde et al. 22057, SAN 143915 (type), 143942, 143948, 144013; Pereira et al. JTP 710, SAN 151222; Postar et al. SAN 143729, 144096. - NE Kalimantan: Jaheri 967.

b. subsp. halimunensis W.J. de Wilde \& Duyfjes, subspec. nov. - Fig. 3c-1; Plate 2

A subsp. chlorocarpa pedicellis masculinis longioribus (5-) $10 \mathrm{~mm}$ longis differt. - Typus:

De Wilde \& Duyfjes 21927 (holo L; iso BO), Java, Halimun Mountains.

Male pedicels 5-10 mm long; male disc with subacute lobes. Fruiting pedicel c. $1 \mathrm{~cm}$ long.

Distribution - W Java: Halimun Mountains.

Habitat \& Ecology - Shaded in montane forest, along rivulets and on slopes; at 800-1500 m altitude; flowering and fruiting throughout the year.

Specimens examined:

De Wilde 21875, 21876, 21877, 21878, 21879; De Wilde et al. 21927 (type), 21928, 22271; Gravendeel et al. 542; Wiriadinata 8145.

2. MELOTHRIA - Fig. 1b, 2b; Table 1

Melothria L. (1753) 35; Naudin (1859) 148; Cogn. (1881) 572, p.p.; (1916) 75, p.p.; Wunderlin (1978) 332. - Type: Melothria pendula L.

Low climbers, subannual; monoecious; green on drying. Probract absent. Tendrils simple, glabrescent. Leaves simple, entire or lobed, palminerved. Flowers small, $5(-8) \mathrm{mm}$ diam., yellow (see note 2); sepals minute, narrow, subpatent; petals free, ovate-elliptic, valvate in bud; receptacle-tube campanulate. Male inflorescence: a slender peduncled raceme, with congested flowers, mostly co-axillary with 1 female flower. Bracts absent. Male flowers: pedicel c. $5 \mathrm{~mm}$ long, slender, persistent; stamens 3 , inserted at c. $1 / 3$ below the throat of the receptacle-tube, filaments short, shorter than the anther, slender, dorsifixed near apex, anthers two 2-thecous, one 1-thecous, included, thecae lateral, straight, connective narrow, not produced; disc subglobose. 
Female flowers solitary or co-axillary with male raceme, rarely 1 in the male raceme; pedicel long; ovary (ellipsoid-)narrowly ovoid, with a slender neck, glabrous; stigma consisting of 3 erect carnose lobes, papillose; staminodes minute (but see note 1 under M. pendula); disc annular, free from the receptacle-tube. Fruit 1, with long slender fruiting pedicel, ellipsoid, small, 1-1.5 cm long, glabrous, purple-black, juicy; dry pericarp membranous. Seeds numerous, compressed, ovate-elliptic, not sculptured, hairy, margin absent, unwinged.

About 10 species in the New World; 1 weedy species introduced in Asia.

Notes -1 . The here presented genus description and the description of M.pendula are largely based on Asian material of that species.

2. According to Wunderlin (1978: 332) the corolla can be yellow or white (in M. dulcis), but we doubt whether the latter species belongs in Melothria.

\section{Melothria pendula L. - Fig. 4; Plate 3c, d}

Melothria pendula L. (1753) 35; Naudin (1859) 148; Cogn. (1881) 586; (1916) 87; Wunderlin (1978) 333; Correll \& H.B. Correll (1982) 1429, f. 624; Diggs, Lipscomb \& O’Kennon (1999) 570; T.-W. Hsu, J.-J. Peng \& H.-Y. Liu (2001) 193, f. 1-3. - Lectotype (Wunderlin, 1978): Herb. Linn. No. 51.1 (LINN), "Habitat in Canada, Virginia, Jamaica". Taken from Linnean Plant Names Database, with Type Image.

Bryonia filiformis Roxb. (1832) 727; (1978) pl. 24, left-hand plant. — Type: not seen, see note 1.

Annual creeper or climber, up to $4 \mathrm{~m}$ long, sparsely hairy, (later) glabrescent; stem $1(-2) \mathrm{mm}$ thick. Leaves: blade subcircular or ovate in outline, 3-6 by $3-6.5 \mathrm{~cm}$, base cordate, margin remotely dentate or shallowly undulate, both surfaces (sparsely) scabrous-hairy; cystoliths minute; petiole $1.5-2.5 \mathrm{~cm}$ long, hairy, hairs $0.5 \mathrm{~mm}$ long. Male inflorescences hairy as the petiole; peduncle $1-2 \mathrm{~cm}$ by $0.2 \mathrm{~mm}$; raceme short, $0.1(-0.5) \mathrm{cm}$ long, with 2-6(-10) crowded flowers. Male flowers: pedicel 3-5(-7) mm long; perianth $5(-8) \mathrm{mm}$ diam.; receptacle-tube c. 2.5 by $2 \mathrm{~mm}$, outside sparsely hairy, inside minutely glandular, especially in the throat; sepals c. $0.5 \mathrm{~mm}$ long; petals $2.5-3$ by $(2.5-) 3 \mathrm{~mm}$, obtuse or retuse, finely glandular, yellow, patent; filaments c. $0.5 \mathrm{~mm}$ long, slender, anthers ellipsoid, c. $1.5 \mathrm{~mm}$ long, connivent but free; disc c. $1 \mathrm{~mm}$ diameter. Female flowers: 1 (or 2); pedicel 10-20 mm long; ovary c. $5 \mathrm{~mm}$ long, with a c. $1 \mathrm{~mm}$ long neck; perianth as in male flower but larger; corolla c. $8 \mathrm{~mm}$ diam.; style c. $2 \mathrm{~mm}$ long; stigma-lobes 3, erect, each 2-lobed at apex, \pm connivent, c. $2 \mathrm{~mm}$ long, carnose, papillose, partly exserted; staminodes 3 , c. $0.5 \mathrm{~mm}$ long, inserted about halfway the receptacle-tube; disc a thick carnose annulus, c. $1 \mathrm{~mm}$ high. Fruit solitary, ellipsoid to narrowly ellipsoid, $0.8-1.5$ by $0.7-1 \mathrm{~cm}$; pericarp when ripe purple-black, thin, when dry leaving the seeds shining through; fruiting pedicel $2-4$ cm long. Seeds numerous, $3.5-4$ by $2-2.5 \mathrm{~mm}$, silvery whitish hairy.

Distribution - A variable widespread species in America: from Texas south to Argentina; introduced into tropical Asia: S China (Macau, see note 1), Taiwan, and Malesia (Sabah, Bali, Celebes, Philippines).

Habitat \& Ecology - Roadsides, beach forest; in crop fields and Oilpalm plantations; at low altitudes; flowering and fruiting throughout the year.

Notes - 1. In the material studied from Sabah the female flowers have minute staminodes. Naudin (1859), who knew the species well, cultivated it in the botanic 


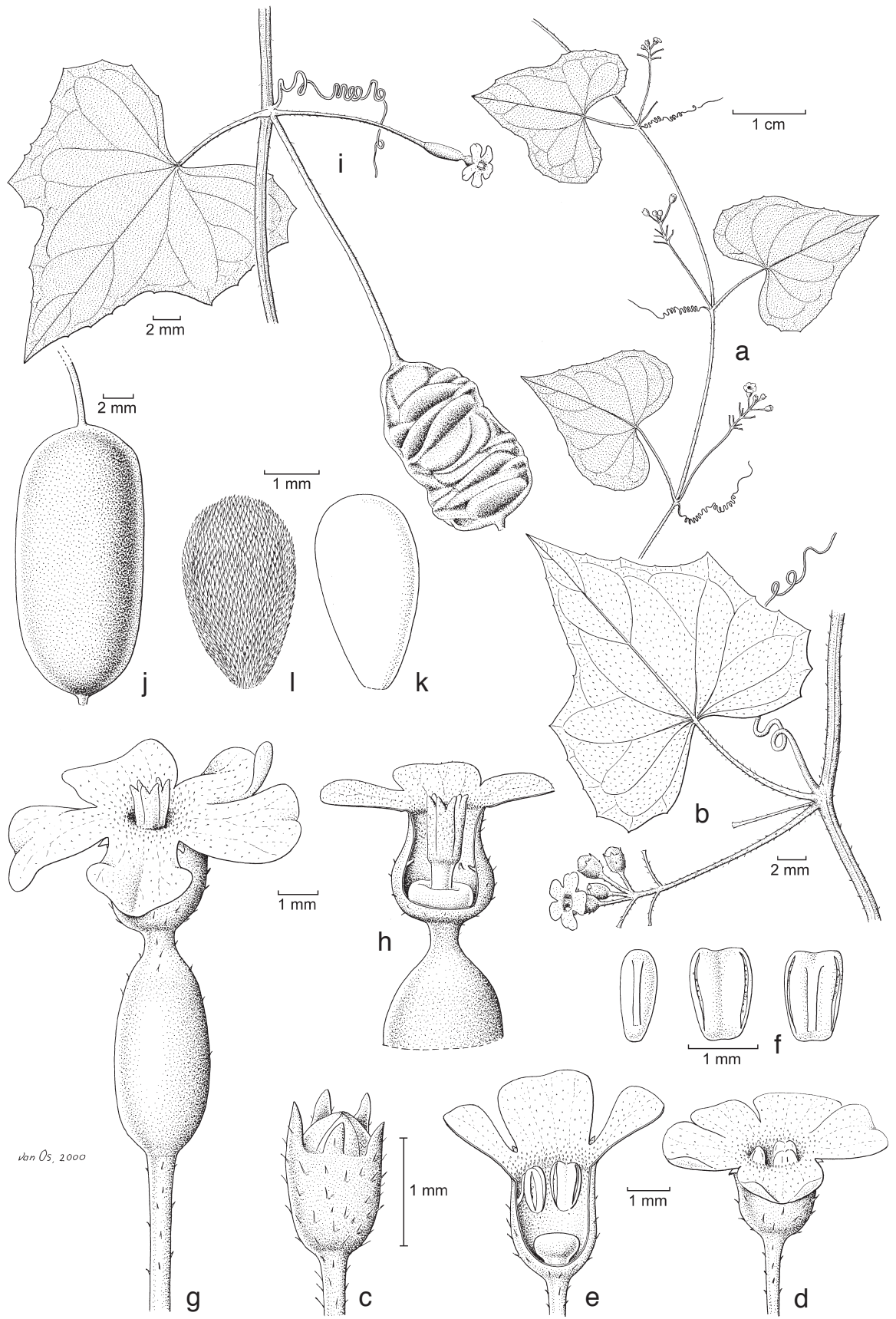

Fig. 4. Melothria pendula L. a. Twig with male inflorescences; b. node with one male inflorescence and one pedicel from fallen female flower; c. male bud; d, e. male flowers; f. anthers with short, narrow filaments; g, h. female flowers; i. node with dried fruit showing seeds; j. fruit (from spirit); k. seed; 1. seed, membrane removed (all: De Wilde \& Duyfjes SAN 141901). 
garden at Paris from seeds sent by the French consul at Macau as well as from seeds from America. He commented on the often hermaphroditic condition of the female flowers.

The species was still earlier cultivated in the botanic garden at Calcutta (Roxburgh, 1832, stating it a native of the Moluccas). We have not seen the original drawing of Roxburgh, Icones no. 1697, but the reproduction of 1978 is clearly showing the characteristic blackish fruit with the long fruiting pedicel. However, all three stamens are erroneously drawn as 2-thecous.

2. Wunderlin (1978) describes the petals as ovate-oblong and acute, whereas other authors explicitly describe the apex as bi-lobed or retuse. In the Sabah material the apex is retuse.

3. According to Wunderlin (1978) M. pendula is a widespread variable weedy species, of which M. guadalupensis (Spreng.) Cogn. and M. fluminensis Gardner are synonyms.

Specimens examined:

De Wilde et al. SAN 139454; Gaerlan et al. PPI 4791; Postar et al. SAN 141901; Van Balgooy 7544 .

\section{NEOACHMANDRA - Fig.1c, 2c; Table 1}

Neoachmandra W.J. de Wilde \& Duyfjes, gen. nov.

AZehneria probractea absenti differt; folia viridia in sicco; flores masculini ad nodos inserti; stamina in dimidio superiore tubi receptaculi inserta; filamenta brevia tenuia conectivum latum apice plerumque protrusa; semina non aut vix marginata. - Typus: Neoachmandra japonica (Thunb.) W.J. de Wilde \& Duyfjes (= Melothria japonica Thunb.).

Achmandra Arn. (1840) 49, p.p., not for the lectotype which is Kedrostis; Arn. (1841, 'Aechmandra') 274; Wight (1842) 267.

Zehneria Endl. subg. Pseudokedrostis (section with Harms (1923) 614) C. Jeffrey (1962) 368. - Type: Melothria pallidinervia Harms, a species from Africa.

Small climbers, usually annual; monoecious; green on drying. Probract absent. Tendrils simple. Leaves simple (seemingly 5-foliolate in N. pentaphylla, New Caledonia), palminerved. Flowers small, c. $5 \mathrm{~mm}$ diam., white; pedicel slender, (sub)articulate at apex; sepals minute, narrowly elliptic or linear, usually recurved; petals free, (narrowly) elliptic, usually valvate in bud; receptacle-tube campanulate. Male inflorescences consisting of 1-4(-8) long-pedicelled flower(s) at the node, usually co-axillary with one (or more) long-pedicelled female flower(s). Bracts absent. Male flowers: pedicel (3-)10-50 mm long, persistent; stamens ( 2 or) 3, inserted in the upper half of the receptacle-tube, filaments short, as long as or shorter than the anther, anthers all 2-thecous, \pm included, thecae lateral, straight, \pm divergent, connective broad, at apex truncate or acutely angular, or sometimes produced; disc free, (depressed-) globose. Female flowers 1 or 2, frequently co-axillary with previously developed male flower(s); pedicel (short or) long; ovary globose or ellipsoid-fusiform, usually with slender neck at apex, glabrous; stigma consisting of ( 2 or) 3 free lobes, papillose-hairy; staminodes usually present; disc annular, free from receptacle-tube. Fruit 1 (or 2), usually with long fruiting pedicel, globose, ellipsoid, narrowly ellipsoid or fusiform, $0.5-7 \mathrm{~cm}$ long, apex beaked or not, glabrous, (pink-)white or red, juicy or pulpy; dry pericarp membranous 
or cartilaginous, smooth or minutely pustulate. Seeds few or numerous, compressed, (globose in N. sphaerosperma), ovate-elliptic, faces little convex, pale, not sculptured, margin absent or obscure, with rounded edge, base without or with short wing.

A genus of c. 30 species distributed in the tropics of the Old World: Africa, Madagascar, and in SE Asia from India, China, Japan south-east through Malesia, and east to Australia and the Pacific; c. 20 species in Asia, Malesia and the Pacific, 1 species in Australia.

Note - With the original publication of the name Achmandra, four species were mentioned, of which the lectotype, Aechmandra rostrata (Rottler) Arn., chosen by Pfeiffer (1873), belongs to the older genus Kedrostis Medik.

\section{KEY TO AUSTRALASIAN AND PACIFIC SPECIES OF NEOACHMANDRA}

1a. Flowers bisexual. [Fruit fusiform, c. $2.5 \mathrm{~cm}$ long.] - Thailand

8. N. hermaphrodita

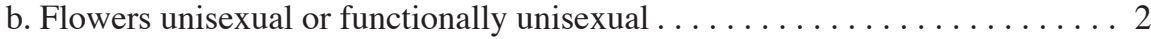

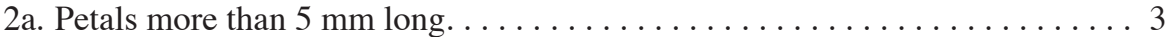

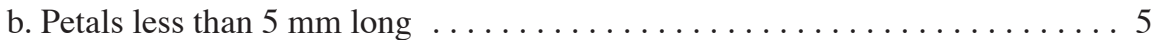

3a. Leaves (narrowly) triangular, at base broadest and truncate . . . . . . . . 4

b. Leaves narrowly elliptic, at base narrowed. - New Guinea. . 12. N. lancifolia

4a. Male flowers 2-4 on each node (female flowers not seen). Receptacle-tube 3.5

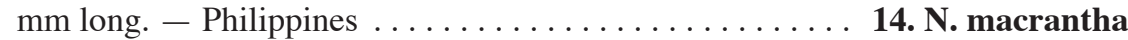

b. Male flowers single (beside 1 female flower) on each node. Receptacle-tube c. $1.5 \mathrm{~mm}$ long. - New Guinea .............. 4. N. clemensiae

5a. Leaves deeply lobed, seemingly 5-foliolate. - New Caledonia

18. N. pentaphylla

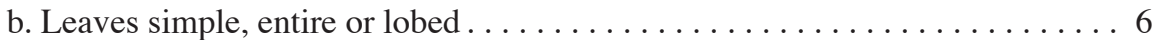

6a. Leaves (3-)5-lobed, lobes to $(1 / 5-)$ halfway deep or more . . . . . . . . 7

b. Leaves lobed less than halfway deep or leaves hastate or entire . . . . . . . 8

7a. Fruit ellipsoid, 1(-1.5) cm long. - Philippines . . . . . 2. N. boholensis

b. Fruit globose, $0.5(-1) \mathrm{cm}$ diameter. - New Guinea . . . . . . . 7. N. filipes

8a. Fruit fusiform, long-tapering at base and apex $\ldots \ldots \ldots \ldots \ldots$

b. Fruit globose, ellipsoid or short-cylindrical, at base short-cuneate or more or less

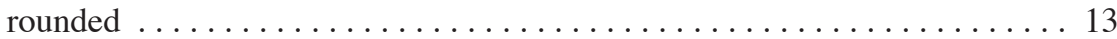

9a. Stem sparsely long-pilose. Fruit 4-6 cm long. - Thailand, Myanmar . . . . . . . $\ldots \ldots \ldots \ldots \ldots \ldots \ldots \ldots \ldots \ldots \ldots \ldots \ldots \ldots \ldots$ 23. N. wallichii

b. Stem (sub) glabrous, minutely hairy or glabrescent. Fruit short or long . . . 10

10a. Fruit 5-6 cm long - Papua New Guinea . . . . . . . 15. N. morobensis

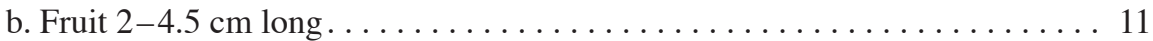

11a. Dry fruit transparent, not ribbed, showing seeds; pericarp very thin. - Samoa

20. N. samoensis

b. Dry fruit not transparent, ribbed; pericarp cartilaginous or coriaceous . . . . 12

12a. Leaves as long as broad. Fruit 2.5-4.5 cm long. - W Malesia: Java, Lesser Sunda

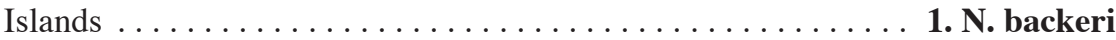

b. Leaves longer than broad. Fruit $2.5-3.5 \mathrm{~cm}$ long. - Sri Lanka, S India, Madagascar, Africa . . . . . . . deltoidea 
13a. Flowers minute, c. $2 \mathrm{~mm}$ diameter. Fruit small, globose, c. $5 \mathrm{~mm}$ diam.; seeds

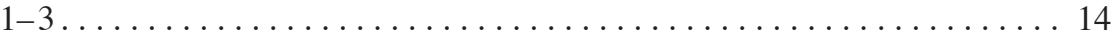

b. Flowers larger. Fruit larger; seeds few or numerous . . . . . . . . . . . 15

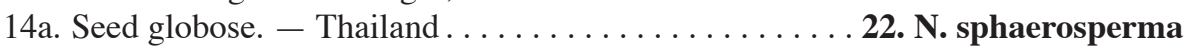

b. Seed compressed. - Thailand ............ 19. N. platysperma

15a. Fruit globose, at apex with a slender acumen. - Thailand . . 3. N. brevirostris

b. Fruit globose or ellipsoid, apex without or with an acumen, but not very slender

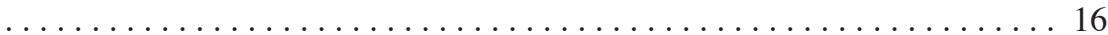

16a. Fruit whitish. Seed 5.5-7 mm long. - Submontane; S Sumatra, Java .......

13. N. leucocarpa

b. Fruit whitish or green. Seed 2-5(-6, in N. japonica) mm long. - Lowlands 17

17a. Leaves narrow, long-triangular, mostly conspicuously long-bristly hairy on the nerves below, hairs $0.5-1.5 \mathrm{~mm}$ long. Ovary sparsely hairy. - Philippines ....

21. N. scaberrima

b. Leaves broader, less conspicuously hairy on nerves below, hairs $1 \mathrm{~mm}$ long or

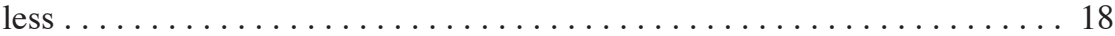

18a. Fruit 2-4 cm long, often irregularly speckled or blotched. - E Java, Lesser Sunda

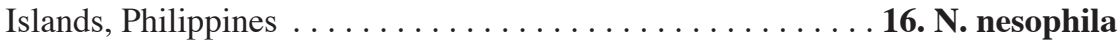

b. Fruit $1-2 \mathrm{~cm}$ long, not speckled . . . . . . . . . . . . . . . . 19

19a. Fruit ellipsoid, 1.5-2 cm long, green. - Moluccas (?), Papua . . . . . . . . .

9. N. idenburgensis

b. Fruit globose or short-ellipsoid, 1-1.5 cm long, whitish. . . . . . . . . 20

20a. Flowers $1-3$ per node. Dry pericarp opaque or transparent . . . . . . . 21

b. Flowers $(1-) 3-8$ per node. Dry pericarp opaque . . . . . . . . . . 22

21a. Dry pericarp filmy, transparent, when dry seeds mostly shining through. Seeds 2-4 mm long. - Widespread ................. 10. indica

b. Dry pericarp thin, opaque, or \pm filmy and transparent. Seeds c. $5 \mathrm{~mm}$ long. -

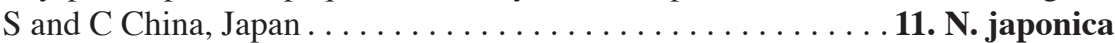

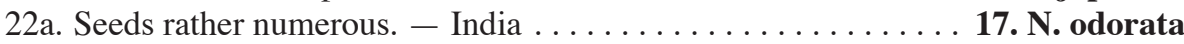

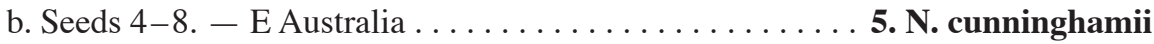

1. Neoachmandra backeri W.J. de Wilde \& Duyfjes, spec. nov.

Fructus $2.5-4.5 \mathrm{~cm}$ longus $0.5-1 \mathrm{~cm}$ diam. breviter acuminatus ad extremis ambobus 6-costatus in sicco pedicello $2-4.5 \mathrm{~cm}$ longo; semina numerosa 3-3.5 mm longa $1.5-2$ mm lata. - Typus: Jaag 466 (holo L), E Moluccas, Alor Islands.

Annual (or subperennial) 1-2 m long climber; stem 0.5-1 mm diam., sparsely finely woolly pubescent, glabrescent. Leaves: blade 3- or 5-angular, or (deeply) 3-lobed, $2-5(-7) \mathrm{cm}$ long and nearly as wide, base broadly rounded or (deeply) cordate, margin shallowly repand-dentate, above scabrous-hairy or with cystoliths; petiole $1-2(-3) \mathrm{cm}$ long, sparsely scabrous-hairy. Male flowers: 1 (or 2) per node, co-axillary with later developing female flower; pedicel 8-15 mm long; expanded perianth 4-8 mm diam.; receptacle-tube $1.5-2$ by $1.5-2.5 \mathrm{~mm}$, inside at throat finely woolly-hairy; sepals $1-1.5$ $\mathrm{mm}$ long; petals $2.5-5 \mathrm{~mm}$ long, subacute, the margin and upper surface minutely papillose-hairy; stamens inserted halfway in the receptacle-tube, filaments $1 \mathrm{~mm}$ long, anthers $1.5 \mathrm{~mm}$ long and wide, connective wide at apex, produced in the middle; disc 1-1.5 mm diameter. Female flowers (subsp. balinensis): single; pedicel 10(-20) $\mathrm{mm}$ 
long; ovary narrowly ellipsoid-fusiform, $8-12$ by $1-1.5 \mathrm{~mm}$, glabrous; receptacle-tube broadly campanulate; style $1.5 \mathrm{~mm}$ long, stigma $2-5 \mathrm{~mm}$ diam., consisting of 3 deeply 2-lobed parts, densely (long-)lanose-papillose; staminodes lanceolate, c. $1.5 \mathrm{~mm}$ long; disc c. $1 \mathrm{~mm}$ high. Fruit solitary, narrowly ellipsoid-fusiform, $2.5-4.5$ by $0.8-1 \mathrm{~cm}$; dry pericarp cartilaginous, light brown, faintly or distinctly (5- or) 6-ribbed; fruiting pedicel $2-4.5 \mathrm{~cm}$ long. Seeds numerous, (narrowly) elliptic, small, $3-3.5$ by $1.5-2$ $\mathrm{mm}$, with faint paler margin.

Distribution - Lesser Sunda Islands (see further under the subspecies).

Note - Neoachmandra backeri is similar to N. thwaitesii from S India and Sri Lanka; the latter differs in its more elongate male receptacle-tube with the anthers included at anthesis (exserted in $N$. backeri), short-papillose stigma-lobes, and often a shorter fruiting pedicel.

\section{KEY TO THE SUBSPECIES}

1a. Expanded male corolla 5-7 mm diam.; petals $2.5-4 \mathrm{~mm}$ long. - Lowlands ... . $\ldots \ldots \ldots \ldots \ldots \ldots \ldots \ldots \ldots \ldots \ldots \ldots \ldots \ldots \ldots \ldots \ldots \ldots \ldots \ldots$. subsp. backeri

b. Expanded male corolla 8-10 mm diam.; petals 4-5 mm long. - Montane . . . . b. subsp. balinensis

\section{a. subsp. backeri}

Expanded corolla 5-7 mm diameter. Fruits 3-5 cm long.

Distribution - Kangean Islands, Lesser Sunda Islands, east to Tanimbar Islands.

Habitat \& Ecology - Climber in open scrub and on beaches; sea level; flowering and fruiting: March to June.

Note - Fruits said to be red when ripe and edible (Backer 28153).

b. subsp. balinensis W.J. de Wilde \& Duyfjes, subsp. nov.

A subspecie typica in floribus maioribus (in partibus omnibus), corolla expansa 8-10 mm diam. differt. - Typus: De Wilde \& Duyfjes 21732 (holo L; iso BO), Bali (Bedugul, growing wild in forest edges in the Botanical Garden).

Expanded corolla 8-10 mm diameter. Fruits c. $3 \mathrm{~cm}$ long.

Field-notes - Tiny climber. Fruits dark green, possibly red when ripe.

Distribution - Endemic to Bali.

Habitat \& Ecology - Climbing on tree trunks in forest edges; at 1400-1800 m altitude.

Specimens examined:

De Wilde \& Duyfjes 21704, 21705, 21732; Van Steenis 8029.

2. Neoachmandra boholensis (Merr.) W.J. de Wilde \& Duyfjes, comb. nov.

Melothria boholenses Merr. (1926) 495. - Type: Ramos BS 42779 (holo UC; iso K), Philippines, Bohol, Kalingohan.

Annual 1-2 m long climber; stem c. $1 \mathrm{~mm}$ diam., sparsely fine-hairy, glabrescent. Leaves: blade subcircular in outline, 2-6 cm diam., (3-)5-lobed to $1 / 5$ deep to nearly 
to the base, segments narrowly elliptic or lanceolate, acute, base truncate or shallowly cordate, margin entire or coarsely shallowly repand-dentate, upper surface scabrous, with cystoliths, lower surface bristly hairy along the nerves; petiole $1-1.5 \mathrm{~cm}$ long, bristly hairy. Male flowers: 1 (or 2) per node, usually co-axillary with 1 (or 2) longerpedicelled female flowers; pedicel $10-12 \mathrm{~mm}$ long; expanded perianth c. $5 \mathrm{~mm}$ diam.; receptacle-tube $2-2.5$ by $2.5-3 \mathrm{~mm}$, at throat finely hairy; sepals $1 \mathrm{~mm}$ long (or less); petals 2-2.5 mm long, blunt or rounded, inside at apex papillose-hairy; stamens inserted close to the throat of the receptacle-tube, filaments c. 1/4 mm long, anthers c. 1 by $1 \mathrm{~mm}$, connective broad, at apex truncate, faintly produced in the middle; disc $(0.5-) 1 \mathrm{~mm}$ diameter. Female flowers: pedicel $15-25 \mathrm{~mm}$ long; ovary narrowly ellipsoid, c. 5 by $2 \mathrm{~mm}$, subglabrous (with sparse hairs); style 1(-1.5) $\mathrm{mm}$ long, with 3 style-arms c. $0.5 \mathrm{~mm}$ long, each with a subellipsoid papillose stigma-lobe of c. $1 \mathrm{~mm}$ diam.; staminodes less than $1 \mathrm{~mm}$ long. Fruit 1 (or 2), ellipsoid, $1.5-2$ by $1-1.5 \mathrm{~cm}$, base rounded, apex narrowly rounded; dry pericarp thin, cartilaginous, almost smooth, pale brown; fruiting pedicel slender, $2-2.5(-4) \mathrm{cm}$ long. Seeds numerous, elliptic, c. 3 by $1.5-2 \mathrm{~mm}$, margin faint.

Field-notes - Corolla white. Ripe fruits green.

Distribution - Islands of the southern Philippines: Bohol, Mindanao, Sulu Archipelago.

Habitat \& Ecology - Climber in recent clearings, also in mangrove forest; at 0 $600 \mathrm{~m}$ altitude; flowering and fruiting throughout the year.

Note - Except for the deeply lobed leaves and rather large fruits, this species comes close to the widespread $N$. indica of which it is possibly only a regional form.

Specimens examined:

Barbon, Romero \& Fernando PPI 1855; Ramos BS 42779 (type); Ramos \& Edaño BS 37215, BS 44212; Reynoso, Alvarez \& Fuentes PPI 7805; University of San Carlos 900.

3. Neoachmandra brevirostris (W.J. de Wilde \& Duyfjes) W.J. de Wilde \& Duyfjes, comb. nov.

Zehneria brevirostris W.J. de Wilde \& Duyfjes (2004) 18. - Type: Newman, Boontavikoon, Hemrat \& Middleton 1152 (holo BKF; iso AAU, E, GH, K, L), Thailand, Sam Roi Yot NP (Prachuap Khiri Khan).

Annual herbaceous delicate c. $1 \mathrm{~m}$ long climber; early glabrescent (few gland-hairs). Leaves: blade (broad-)triangular, rarely subhastate, $2-5.5$ by $3-6 \mathrm{~cm}$, base truncatecordate, apex acute-acuminate, margin short remotely dentate, sometimes \pm wavy, finely scabrid above, nerves minutely sparingly harshly hairy; petiole $1-2.5 \mathrm{~cm}$ long. Flowers: perianth (3-)4 mm diam.; male flowers solitary, usually co-axillary with later developing female flowers, on the main nodes, or in somewhat reduced 2-4 cm long lateral shoots. Male flowers: pedicel slender, 7-10 cm long, glabrous; receptacle-tube narrowly cup-shaped, 1.5 by $1.5 \mathrm{~mm}$, inside and outside glabrous; sepals \pm outcurved, $0.3-0.4 \mathrm{~mm}$ long; petals $1.5-2$ by $0.7-1 \mathrm{~mm}$, subacute (blunt), minutely papillosehairy at apex; stamens inserted slightly below the receptacle-throat, filaments $0.3 \mathrm{~mm}$ long, glabrous, anthers subtruncate-obovate, $0.8-1$ by $0.4 \mathrm{~mm}$, thecae straight, 0.8 $\mathrm{mm}$ long, connective \pm broad, slightly produced, glabrous; disc subglobose, c. $0.5 \mathrm{~mm}$ diameter. Female flowers: pedicel $4-6 \mathrm{~mm}$ long; ovary ovoid-fusiform, $2-4$ by $1-2$ 
$\mathrm{mm}$, glabrous, neck 1.5-2 mm long; perianth considerably smaller than in male, $2 \mathrm{~mm}$ diam.; receptacle-tube 1 by $1 \mathrm{~mm}$, glabrous (except few minute hairs in throat); sepals $0.2 \mathrm{~mm}$ long; petals $1 \mathrm{~mm}$ long; style $1 \mathrm{~mm}$ long, glabrous, stigma deeply 3-lobed, $0.5 \mathrm{~mm}$ diam., finely papillose; disc $0.2 \mathrm{~mm}$ high. Fruit subglobose, 6-8 mm diam., apex slenderly 2-3 mm beaked (beak may be broken off), smooth, glabrous; fruiting pedicel (0.4-) 0.8-1.2 cm long. Seeds 5-10 per fruit, flat, ovate, 5 by $3 \mathrm{~mm}$, hardly margined, with square edge, faces smooth or shallowly warted.

Field-note - Ripe fruits orange.

Distribution - Endemic to Thailand.

Habitat \& Ecology - On limestone rock; at 50-400 m altitude; flowering and fruiting: June to December.

Specimens examined:

Den Hoed \& Kostermans 680; Kerr 19842; Kostermans 1096; Koyama et al. T 31187; Larsen et al. 1193, 45353; Newman et al. 1152 (type); Put 1821; Van Beusekom et al. 3983.

4. Neoachmandra clemensiae (Merr. \& L.M. Perry) W.J. de Wilde \& Duyfjes, comb. nov.

Melothria clemensiae Merr. \& L.M. Perry (1948) 168. - Type: M.S. Clemens 41287 (holo A, not seen; iso MICH), Papua New Guinea, Morobe, Sugu-Gaeng.

Annual or subperennial $2 \mathrm{~m}$ long climber; ?polygamous (see under female flowers); stem c. $1 \mathrm{~mm}$ diam., sparsely fine-hairy, glabrescent. Leaves: blade entire, narrowly triangular, $4-6$ by $2-3 \mathrm{~cm}$, base broadly truncate, margin entire, with short teeth less than $1 \mathrm{~mm}$ long, upper surface scabrous with cystoliths, lower surface sparsely scabrous-hairy, on nerves hairs longer and denser; petiole $0.9-1.4 \mathrm{~cm}$ long, densely bristly hairy. Male flowers: single, or often co-axillary with 1 female flower, glabrous; pedicel c. $20 \mathrm{~mm}$ long; expanded perianth c. $15 \mathrm{~mm}$ diam.; receptacle-tube c. 1.5 by $3 \mathrm{~mm}$, at throat hardly hairy; sepals $0.5(-1) \mathrm{mm}$ long; petals $6-7$ by $2-3(-4) \mathrm{mm}$, subacute, subglabrous; stamens inserted slightly below the throat of the receptacle-tube, filaments less than $0.5 \mathrm{~mm}$ long, anthers 1.5 by $1.5 \mathrm{~mm}$, connective broad, at apex truncate, not or slightly produced; disc depressed globose, less than $1 \mathrm{~mm}$ diameter. Female flowers: pedicel 30-40(-45) mm long; ovary much elongated, $12(-15)$ by $1-1.5 \mathrm{~mm}$, at apex contracted into a narrow neck $2.5-3 \mathrm{~mm}$ long, glabrous; receptacle-tube c. 2.5 by 3.5 $\mathrm{mm}$; style 1.5(-2) mm long, stigma-lobes each c. $1.5 \mathrm{~mm}$ diam.; staminodes c. $2 \mathrm{~mm}$ long, inserted slightly above the base of the receptacle-tube, each consisting of a 1-1.5 $\mathrm{mm}$ long filament with at apex a reduced 2-thecous anther $0.5 \mathrm{~mm}$ long, lined with few hairs; disc nearly $1 \mathrm{~mm}$ high, the upper rim \pm undulating. Fruits not known.

Distribution - Endemic to Papua New Guinea, Sugu-Gaeng, Morobe Prov.; known only from the type.

Habitat \& Ecology - Along mountain trail on wet place; at 1000-1200 m altitude; flowering in April.

Note - The type and only known collection M.S. Clemens 41287 is a richly flowering specimen, with one male and one female flower at each node. The female flowers all seem to be hermaphroditic, as the staminodes bear well-developed anthers, though much smaller than those of the male flowers. The staminodes are much lower inserted in the receptacle-tube compared to the stamens in the male flowers. The thecae in the staminodes apparently do not open, and do not produce fertile-looking pollen. 
5. Neoachmandra cunninghamii (F. Muell.) W.J. de Wilde \& Duyfjes, comb. nov.

Zehneria cunninghamii F. Muell. (1856) 50; I. Telford (1982) 181. - Melothria cunninghamii (F. Muell.) Benth. (1866) 320. - Lectotype (here chosen): Mueller s.n. (TCD), Australia, Queensland, Moroton Bay.

Distribution - E Australia: Queensland.

Note - Neoachmandra cunninghamii is still insufficiently known, especially where its relation to $N$. odorata and $N$. indica is concerned, both being similar species from SE Asia and Malesia.

Specimens examined:

Coveny 675; Dietrich 347; Mueller s.n. (lectotype); Tracey 25756.

6. Neoachmandra deltoidea (Arn.) W.J. de Wilde \& Duyfjes, comb. nov.

Aechmandra deltoidea Arn. (1841) 274. - Bryonia deltoidea Arn. (1836) 337, nom. illeg. (not Bryonia deltoidea Schumach. (1827) 429). - Melothria deltoidea (Arn.) Thwaites (1859) 124. - Melothria zeylanica C.B. Clarke (1879) 626; Chakrav. (1959) 154; (1982) 87. - Type: Walker 273 (holo K), Ceylon..

Melothria thwaitesii Schweinf. (1868) 44, t. 29, p.p. - Zehneria thwaitesii (Schweinf.) C. Jeffrey (1962) 371; (1967) 128; (1980b) 795; Keraudren (1966) 40, f. 9; Philcox (1997) 42. - Lectotype (here chosen): Thwaites CP 2581 (K; iso $\mathrm{B} \dagger, \mathrm{BM}, \mathrm{P}, \mathrm{W})$, Ceylon (see note).

Distribution - Tropical Africa and Madagascar, southern India, Sri Lanka.

Note - The syntype of $N$. thwaitesii consists of elements from W Africa and Ceylon.

Specimens examined:

Kostermans 23050, 25093; Thwaites CP 1610, CP 2581, CP 3128; C.F. \& R.J. van Beusekom 1373; Walker 273 (type).

7. Neoachmandra filipes (Merr. \& L.M. Perry) W.J. de Wilde \& Duyfjes, comb. nov.

Melothria filipes Merr. \& L.M. Perry (1948) 167. - Type: M.S. Clemens 11027 (holo A; iso MICH), Papua New Guinea, Morobe.

Annual or subperennial 1-2 m long climber; stem 0.5-1 mm diam., sparsely hairy. Leaves: blade circular or broadly ovate in outline, 4-11 cm diam., palmately (3-)5-lobed to c. 3/4 deep to (nearly) to the base, base truncate or widely shallowly emarginate, margin entire or widely minutely repand-dentate, upper surface densely \pm appressedly scabrous-hairy, lower surface bristly hairy on the nerves, cystoliths not obvious; lobes narrowly elliptic or lanceolate (or linear), mid-lobe usually largest, up to 8 by 1(-2) $\mathrm{cm}$; petiole 1-3 cm long, finely rigidly hairy. Male flowers: single, co-axillary with a single somewhat later developing longer-pedicelled female flower; pedicel 12-20 mm long; expanded perianth $6-8 \mathrm{~mm}$ diam.; receptacle-tube 1.5 by $2 \mathrm{~mm}$, finely hairy in the throat; sepals $1 \mathrm{~mm}$ long; petals 3-4 mm long, subacute, inside very finely hairy; stamens inserted halfway the receptacle-tube, filaments slender, $1(-1.5) \mathrm{mm}$ long, anthers 0.8 by $1 \mathrm{~mm}$, thecae diverging to the apex, connective broad, at apex angularly protruding; disc depressed globose, $1 \mathrm{~mm}$ diameter. Female flowers: pedicel 
15-25(-40) mm long, filiform; ovary nearly globose, $2 \mathrm{~mm}$ diam., glabrous, at apex contracted into a narrow neck $1 \mathrm{~mm}$ long; receptacle-tube 1.5 by $2 \mathrm{~mm}$, finely hairy in the throat; sepals $0.5(-1) \mathrm{mm}$ long; petals $2-2.5 \mathrm{~mm}$ long, inside papillose-hairy; style $1.5 \mathrm{~mm}$ long, stigma 3-lobed, depressed-globose, nearly $1 \mathrm{~mm}$ diam., papillosehairy; staminodes $0.3 \mathrm{~mm}$ long; disc $0.5 \mathrm{~mm}$ high. Fruit solitary, subglobose, $0.5(-1)$ cm diam.; dry pericarp thin, papery, smooth, pale brown; fruiting pedicel very slender, $1.5-6(-8) \mathrm{cm}$ long. Seeds $4-10$ per fruit, ovate, 5 by $3-3.5 \mathrm{~mm}$, smooth, with thickened rounded margin.

Field-notes - Locally common. Flowers creamy or white and the ripe fruits pink or orange.

Distribution - Endemic to Papua New Guinea: Central, Western Highlands, Eastern Highlands, Morobe, Madang Provinces.

Habitat \& Ecology - In tall grassland, clearings and forest edges in montane area; at 1000-2000 $\mathrm{m}$ altitude; flowering and fruiting throughout the year.

\section{Neoachmandra hermaphrodita (W.J. de Wilde \& Duyfjes) W.J. de Wilde \&} Duyfjes, comb. nov. - Fig. 5; Plate $4 \mathrm{a}-\mathrm{c}$

Zehneria hermaphrodita W.J. de Wilde \& Duyfjes (2004) 19. - Type: De Wilde \& Duyfjes 22289 (holo BKF; iso L), Thailand, Kaeng Krachan NP (Kanchaburi).

Slender annual or biennial 1-2 m long creeper or climber; early glabrescent. Leaves: blade broadly triangular-ovate, $2.5-10$ by $2-8 \mathrm{~cm}$, base broadly cordate (with wide sinus), apex acute-acuminate, margin straight or faintly undulate, with sparse minute teeth $(0.2 \mathrm{~mm}$ long), scabrid above by minute cystoliths; petiole $1-3.5 \mathrm{~cm}$ long, sparsely short rough-hairy. Flowers hermaphroditic, solitary on the nodes; pedicel 3-8 mm long, glabrous or with sparse minute hairs $0.2 \mathrm{~mm}$ long; perianth $5 \mathrm{~mm}$ diam.; ovary fusiform, $8-13$ by $1.5-3 \mathrm{~mm}$, glabrous, at apex longer tapering than at base, neck $1 \mathrm{~mm}$ long; receptacle-tube cup-shaped, 2 by $2 \mathrm{~mm}$, glabrous except few short hairs $(0.1-0.2 \mathrm{~mm}$ long) inside at throat; sepals $0.5 \mathrm{~mm}$ long, slightly outcurved; petals $2.5-3$ by $1.5-2$ $\mathrm{mm}$, blunt (subacute), short papillose-hairy; filaments $1 \mathrm{~mm}$ long, inserted halfway the receptacle, glabrous, anthers obovoid-rhomboid, 1 by $1 \mathrm{~mm}$, thecae $1 \mathrm{~mm}$ long, connective broad, glabrous, broadest at apex, shortly produced adaxially; style $1.5 \mathrm{~mm}$ long, $0.3 \mathrm{~mm}$ thick, glabrous, stigma obconical, $1.5 \mathrm{~mm}$ diam., situated partly below and inside the anthers, consisting of 3 largely adnate lobes, which are narrowed and shallowly notched at apex; disc carnose, \pm obconical, cup-shaped, 1 by $1 \mathrm{~mm}$. Fruit broadly fusiform, c. 2.5 by $1 \mathrm{~cm}$, strongly beak-like narrowed at base and apex, basal and apical beaks (5-)7-10 mm long, pale green; fruiting pedicel 0.7-2 cm long. Seeds $15-25$ per fruit, (narrowly) ovate, $5-7$ by $3-3.5 \mathrm{~mm}$, smooth, hardly margined.

Field-note - Fruits whitish green when ripe with faint green stripes.

Distribution - SW Thailand, a local endemic.

Habitat \& Ecology - Roadsides in evergreen (secondary) forest; at 100-600 m altitude; flowering and fruiting: August to December.

Specimens examined:

De Wilde \& Duyfjes 22289 (type); Koonkhunthod, De Wilde \& Duyfjes 330; Middleton, Suddee \& Hemrat 1249; Phonsena, De Wilde \& Duyfjes 4409; 4424. 


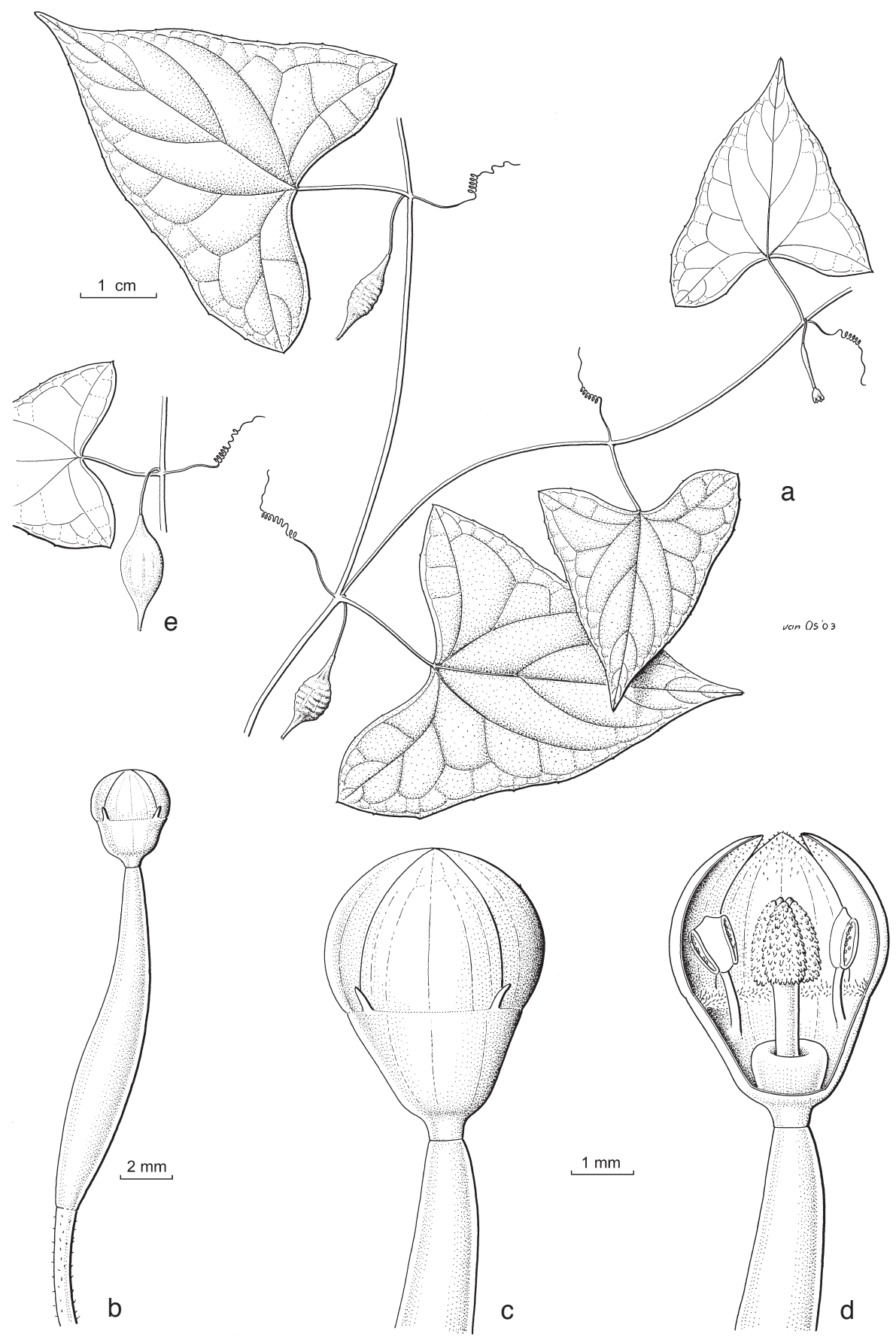

Fig. 5. Neoachmandra hermaphroditica (W.J. de Wilde \& Duyfjes) W.J. de Wilde \& Duyfjes. a. Habit with fruiting nodes on main branch, flower on lateral branch; $b-d$. flowers; e. fruit (from alcohol material) (all: De Wilde \& Duyfjes 22289, type). 
9. Neoachmandra idenburgensis (Merr. \& L.M. Perry) W.J. de Wilde \& Duyfjes, comb. nov.

Melothria idenburgensis Merr. \& L.M. Perry (1949) 57. - Type: Brass 14100 (holo A; iso BM, BO), Indonesia, Papua, Idenburg River.

Annual c. $1 \mathrm{~m}$ long climber; stem c. $1 \mathrm{~mm}$ diam., glabrescent. Leaves: blade ovate, (long) triangular or subhastate, $3.5-11$ by $2-6 \mathrm{~cm}$, base with broadly triangular sinus up to $2 \mathrm{~cm}$ deep, basal lobes subobtuse, upper surface finely scabrous with minute cystoliths, lower surface smooth, nerves sparsely finely hairy; petiole 1-2.5 cm long, (sparsely) hairy. Male flowers 1 or 2, frequently co-axillary with one equally longpedicelled female flower (or fruit); pedicel 7-12 mm long, (sub)glabrous; expanded perianth c. $7 \mathrm{~mm}$ diam.; receptacle-tube 2 by $2 \mathrm{~mm}$, glabrous, minutely hairy in the throat; sepals $1 \mathrm{~mm}$ long; petals $2.5-3 \mathrm{~mm}$ long, inside and on margin towards apex minutely glandular-hairy; stamens inserted close to the throat of the receptacle-tube, filaments $0.3 \mathrm{~mm}$ long, anthers 1.3 by $1.3 \mathrm{~mm}$, connective truncate, faintly protruding in the middle; disc depressed globose, $1 \mathrm{~mm}$ diameter. Female flowers: not seen (ovary described in original description as fusiform). Fruit: solitary, co-axillary with pedicel of dropped male flower, ellipsoid, $1.5-1.7$ by $1-1.2 \mathrm{~cm}$, base rounded, apex (narrowly) rounded with minute point; dry pericarp thinly pergamentaceous, opaque, not transparent; fruiting pedicel c. $1 \mathrm{~cm}$ long. Seeds numerous, ovate-elliptic, 3.5-4 by $2-2.5 \mathrm{~mm}$, with narrow paler margin, basal wing c. $2 \mathrm{~mm}$ long.

Field-notes - Flowers white. Fruits unripe (but see note 2).

Distribution - Indonesia: Papua, Idenburg River, Bernhard Camp; known only from the type.

Habitat \& Ecology - The herbarium label mentions the plant as "occasional in fringe vegetation along stream in rainforest"; at $50 \mathrm{~m}$ altitude; flowering and fruiting in April.

Notes - 1. Neoachmandra idenburgensis in general aspect, including the male flowers, resembles $N$. indica, but it also resembles unnamed small-fruited specimens mentioned under $N$. nesophila. Neoachmandra indica differs in longer and more slenderly pedicelled smaller fruits, which are whitish when ripe, transparent and juicy inside, releasing unwinged seeds. The smaller-fruited specimens noted under N. nesophila have larger and longer-pedicelled fruits.

2. The fruits are reported as unripe, but fruits in both duplicate collections contain mature seeds. Therefore, ripe fruits are possibly green.

10. Neoachmandra indica (Lour.) W.J. de Wilde \& Duyfjes, comb. nov. - Plate 4d, e

Melothria indica Lour. (1790) 35; Backer (1964) 297. - Aechmandra indica (Lour.) Arn. (1841) 274.

- Zehneria indica (Lour.) Keraudren (1975b) 52, pl. 9: 5-8; C. Jeffrey (1980a) 17; A.M. Lu \& Zhi Y. Zhang (1986) 170, pl. 45: 1-8; W.J. de Wilde \& Duyfjes (2004) 19. - Type (Keraudren, 1975b): Loureiro s.n. (holo BM), Tourane, Viêt-nam; not found; neotype (C. Jeffrey, 1980b): Squires 14 (BM; iso K, UC, W), Hue, Viêt-nam.

Bryonia geminata Blume (1826) 924. - Lectotype (here chosen): Zippelius 1564 (L), West Java. Bryonia tenella Roxb. (1832) 725; (1978) pl. 24, right-hand specimen. - Type: not seen.

Cucumis luzonicus Blanco (1837) 861; Merr. (1918) 470. - Neotype (here chosen): Merrill: Species Blancoanae 848 (US, not seen; iso K, L, W), Rizal Prov., Luzon.

Zehneria japonica auct. non (Thunb.) H.Y. Liu: S.K. Chen (1995) 314, pl. 82: 6-9, p.p. 
Subannual slender $0.5-1.5 \mathrm{~m}$ long creeper or climber; largely glabrescent, hairs less than $0.5 \mathrm{~mm}$ long. Leaves: blade triangular or (deeply) hastately 3(-5)-lobed, 2.5-7(-10) by $3-5.5(-7) \mathrm{cm}$, base broadly shallowly cordate or subtruncate, apex acute-acuminate, margin faintly dentate; petiole $1-3 \mathrm{~cm}$ long, finely hairy or glabrescent. Flowers: perianth 4-7 mm diam., male flowers solitary (or paired?), usually co-axillary with 1 or 2 previously developed, longer-pedicelled female flower(s), glabrous (but sparsely gland-dotted). Male flowers: pedicel slender, 10-15 mm long; receptacletube \pm narrowly cup-shaped, $1.5-2$ by $1.5-2 \mathrm{~mm}$, glabrous, except for hairy fringe at throat inside; sepals $(0.5-) 1 \mathrm{~mm}$ long, glabrous, recurved; petals $2-3.5$ by $1.5-2 \mathrm{~mm}$, inner and outer surface minutely gland-hairy and papillose; filaments $0.5 \mathrm{~mm}$ long, glabrous, inserted $0.5(-1) \mathrm{mm}$ below the throat of the receptacle-tube, anthers obovoidrhomboid, 1-1.5 mm diam., thecae straight, $1 \mathrm{~mm}$ long, connective broad, broadest at apex, subtruncate with short $0.2 \mathrm{~mm}$ projection, (partly) finely hairy; disc elongated, \pm obovate-elliptic, $1 \mathrm{~mm}$ long. Female flowers: pedicel (10-)15-30 mm long; ovary ellipsoid to narrowly ellipsoid, 3(-4) by $1.5-2 \mathrm{~mm}$, glabrous, neck $0.5-1 \mathrm{~mm}$ long; perianth as in male flowers; style $1.5(-2) \mathrm{mm}$ long, stigma $1 \mathrm{~mm}$ diam., composed of 3 apically deeply notched lobes, papillose; staminodes linear, $1 \mathrm{~mm}$ long, inserted halfway the tube; disc thick-carnose, $1 \mathrm{~mm}$ high. Fruit 1 or 2 per node, subglobose or (short) ellipsoid, not apiculate, $8-12$ by $8-10 \mathrm{~mm}$; pericarp thinly leathery or membranous (when dry often leaving the seeds shining through); fruiting pedicel 15-30 mm long. Seeds $15-25$ per fruit, \pm obovate, $2-4$ by $2.5-3 \mathrm{~mm}$, smooth, unmargined, with smooth, rounded edge.

Distribution - Widespread: from S India and S China east to West Malesia (Borneo, Java, Philippines); no known collections from Sumatra and Peninsular Malaysia. In northern India the distinction with Zehneria odorata is not sharp, as is the distinction with Z. japonica in southern China.

Habitat \& Ecology - In and along waste gardens, forest edges, shaded roadsides; at $0-500(-1400) \mathrm{m}$ altitude; flowering and fruiting mainly July to December.

Note - The fruit colour is rarely recorded as whitish; apparently the fruit is shortlived or frequently early picked by animals.

\section{Neoachmandra japonica (Thunb.) W.J. de Wilde \& Duyfjes, comb. nov.}

Bryonia japonica Thunb. (1784) 870. - Melothria japonica (Thunb.) Cogn. (1881) 599; Makino (1961) 607, with fig.; Ohwi (1965) 848. - Zehneria japonica (Thunb.) H.Y. Liu (1989) 40;

C. Jeffrey (1990) 7. - Type: UPS-THUNB 22826, Japan, Nagasaki, not seen.

Melothria regelii Naudin (1866) 35. - Type: cultivated in Paris, not seen.

Melothria formosana Hayata (1911) 120. - Type: Nakahara 592 (TI, not seen), Taiwan, Rokkirisha.

Distribution - E, SE and S China, Korea, Japan; possibly in northern Vietnam.

Note - Neoachmandra japonica is close to N. indica; the differences are mainly in the seed size and even this needs confirmation.

\section{Neoachmandra lancifolia W.J. de Wilde \& Duyfjes, spec. nov.}

Neoachmandra clemensiae similis foliis lanceolatis scabre pubescentibus sine cystolithis differt; flores masculini 3-5 ad unoquoque nodo, tubi receptaculum longius 3.5-4 mm longus. - Typus: Paijmans 1107 (holo CANB; iso LAE), Papua New Guinea, south side of Goodenough Bay, Milne Bay Province. 
Annual(?) herbaceous c. $2 \mathrm{~m}$ long climber; stem c. $1 \mathrm{~mm}$ diam.; early glabrescent. Leaves: blade lanceolate, parallelly 5 -nerved, $5-8$ by $0.5-1 \mathrm{~cm}$, base narrowed but \pm rounded or subcordate, apex subacute with mucro, margin with sparse teeth $0.5 \mathrm{~mm}$ long or less, both surfaces densely short-scabrous hairy, hairs directed towards the apex; petiole $0.5-0.9 \mathrm{~cm}$ long, with dense, scabrous, upwards-directed hairs. Male flowers: 3-5 per node (female flowers not present), subglabrous; pedicel $20-25 \mathrm{~mm}$ long; expanded perianth 15-20 mm diam.; receptacle-tube narrowly campanulate, $3.5(-4)$ by c. $2.5 \mathrm{~mm}$, inside at throat densely finely hairy; sepals $2.5-3 \mathrm{~mm}$ long, with an odd hair; petals $6-8$ by $3-4 \mathrm{~mm}$, along the margin minutely papillose; stamens inserted at c. $1 / 3$ from the apex in the receptacle-tube, filaments slender, (1-) $1.5 \mathrm{~mm}$ long, anthers c. 1.5 by $1 \mathrm{~mm}$, exserted, hairy along the thecae, connective broad, with truncate apex, minutely produced in the middle; disc obovoid, c. 1.5 by $1 \mathrm{~mm}$. Female flowers and fruits not seen.

Distribution - Papua New Guinea: Milne Bay Prov., south side of Goodenough Bay; known only from the type.

Habitat \& Ecology - In grassland on plateau; at c. $250 \mathrm{~m}$ altitude.

Note - This species seems closely related to $N$. scaberrima which has much smaller flowers.

13. Neoachmandra leucocarpa (Blume) W.J. de Wilde \& Duyfjes, comb. nov. Fig. 6; Plate 5a, b

Bryonia leucocarpa Blume (1826) 924. - Bryonopsis? leucocarpa (Blume) Miq. (1856) 657. - Melothria leucocarpa (Blume) Cogn. (1881) 601, p.p.; (1916) 101, p.p.; Backer (1964) 297.

- Lectotype (here chosen): Blume s.n., barcode L0130099 (L), Java.

Zehneria deltoidea Miq. (1856) 655. - Melothria rauwenhoffii Cogn. (1881) 597; (1916) 97 (not Melothria deltoidea (Schumach. \& Thonn.) Benth. (1849) 368). - Type: Junghuhn s.n., barcode U0001468 (holo U; iso L, barcode L0130089), Java, Gunung Merapi.

Zehneria deltoidea Miq. $\beta$ subintegerrima Miq. (1856) 655. - Type: Horsfield s.n. (holo U), Java. Melothria rauwenhoffii Cogn. var. pengalenganensis Hochr. (1934) 287. - Type: Hochreutiner 1316 (holo G; iso L), Java, Pengalengan Plateau.

Annual or subperennial to c. $5 \mathrm{~m}$ long climber; stem 1-2 mm diam.; minutely sparsely hairy, glabrescent. Leaves: blade broadly triangular or subhastate, $4-11$ by $3-9.5 \mathrm{~cm}$, base cordate, truncate or broadly emarginate, margin entire or shallowly dentate, upper surface glabrous except for the scabrid-hairy nerves, with numerous cystoliths, lower surface glabrous, without cystoliths; petiole $1.5-3.5 \mathrm{~cm}$ long, scabrid short-hairy. Male flowers: 1 or 2 per node, usually co-axillary with 1 or 2 longer-pedicelled female flower(s); pedicel 25-45 mm long, glabrous; expanded perianth 8-10 $\mathrm{mm}$ diam.; receptacle-tube c. 3.5 by $3 \mathrm{~mm}$, densely minutely papillose-hairy in the throat; sepals $1 \mathrm{~mm}$ long; petals 3-5 mm long, subacute, inside minutely papillose-hairy; stamens inserted near the throat in the receptacle-tube, filaments $0.5 \mathrm{~mm}$ long, anthers c. 2 by $1.5 \mathrm{~mm}$, connective broad, at apex truncate with a short mucro in the middle; disc \pm globose, 1-1.5 mm diameter. Female flowers: 1 or 2; pedicel (10-)30-60 mm long; ovary fusiform, c. 9 by $3 \mathrm{~mm}$, glabrous, with a c. $2 \mathrm{~mm}$ long neck; style c. $4 \mathrm{~mm}$ long, stigma depressed globose, 1.5 by $1 \mathrm{~mm}, 3$-lobed, and each lobe again 2-lobed, papillose; staminodes $0.5 \mathrm{~mm}$ long; disc $1 \mathrm{~mm}$ high, shallowly 3-lobed. Fruit 1 or 2, subglobose or ellipsoid, $1-2$ by $0.8-1.5 \mathrm{~cm}$, base subobtuse, apex (sub)obtuse, $1 \mathrm{~mm}$ 


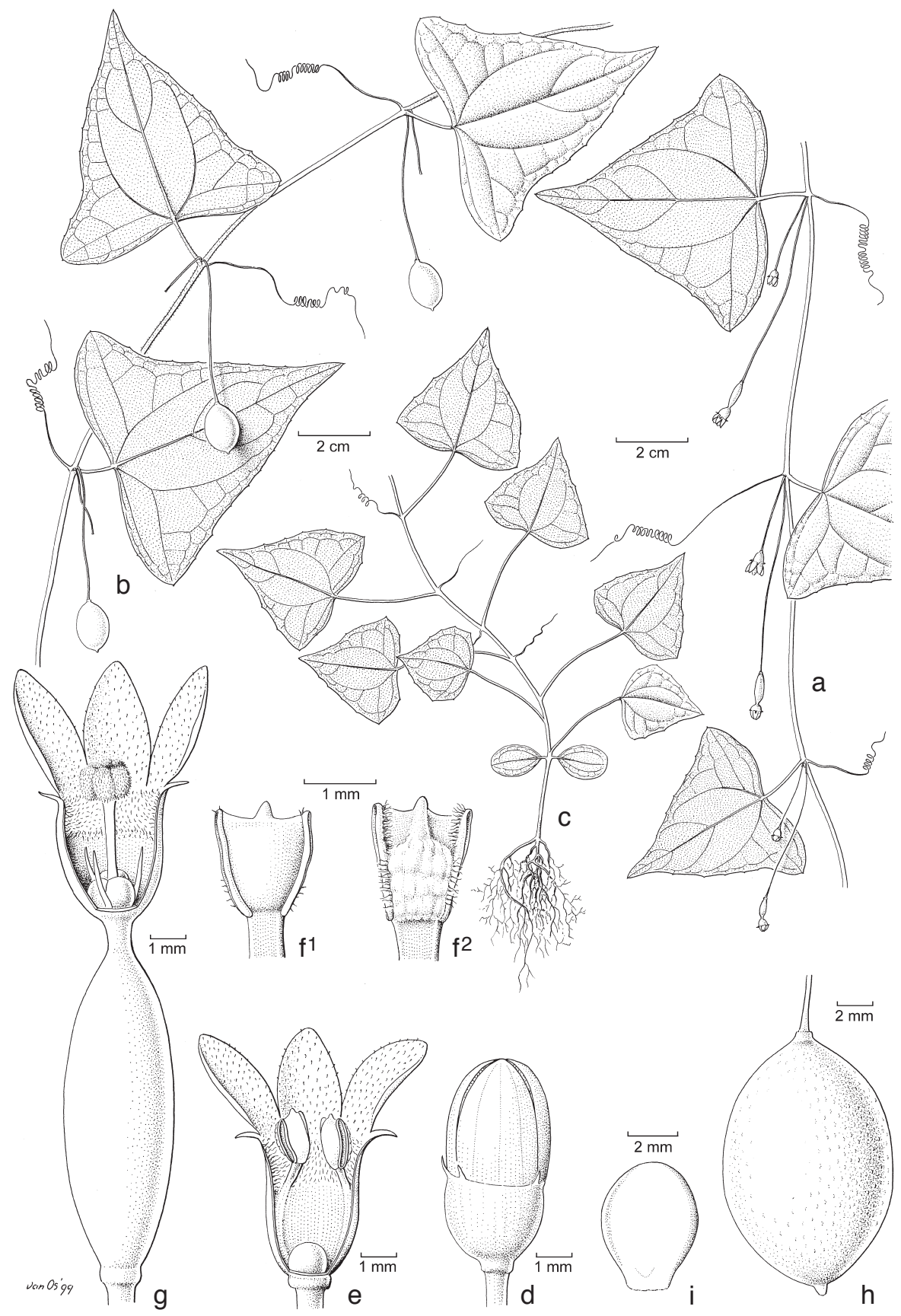

Fig. 6. Neoachmandra leucocarpa (Blume) W.J. de Wilde \& Duyfjes. a. Twig with male and female flowers; $b$. twig with fruits; c. seedling; $d$, e. male flowers; $\mathrm{f}^{1}, \mathrm{f}^{2}$. anthers, showing thecae with broad connective, ad- and abaxially, respectively; g. female flower; h. fruit; i. seed (a, b, d-g: De Wilde \& Duyfjes 21843; c, h, i: De Wilde \& Duyfjes 21946). 
beaked; dry pericarp thin, pale brown, smooth; fruiting pedicel (1-) $4-6 \mathrm{~cm}$ long. Seeds 5-12 per fruit, elliptic, $6-7$ by c. $4 \mathrm{~mm}$, margin faint, without wing.

Field-notes - Plant widely branched. Lower leaf surface very pale. Perianth white or pale creamy-white. Anthers dorsally with a ridge (as indicated in a drawing by Kuhl \& Van Hasselt s.n., barcode L0130076). Fruits at first greenish white, pink-white when ripe. Cotyledons in the seedling measure c. 1.5 by $1 \mathrm{~cm}$.

Distribution - Central and southern Sumatra (3 collections), all over Java.

Habitat \& Ecology - Forest edges and damp places in montane forest, often near streams; at 850-1750 $\mathrm{m}$ altitude; flowering and fruiting throughout the year.

\section{Neoachmandra macrantha W.J. de Wilde \& Duyfjes, spec. nov.}

Prope Neomachandram clemensiae, floribus masculinis 2-4 unoquoque nodo, pedicellis longioribus, tubi receptaculo longiore c. $3.5 \mathrm{~mm}$ longo differt. - Typus: Ramos \& Edaño BS 40215 (holo P; iso K, UC), Philippines, Luzon, Mt Data.

Possibly annual 1-2 m long climber; stem $0.5-1 \mathrm{~mm}$ diam.; sparsely hairy. Leaves: blade entire, (narrowly) triangular, $4-6.5$ by $2-3.5 \mathrm{~cm}$, base truncate, apex long-acuminate with short mucro, margin shallowly sparsely repand-dentate, teeth $1-1.5 \mathrm{~mm}$ long, upper and lower surface scabrous with short hairs and cystoliths, nerves with scabrid hairs; petiole $0.5-1.5 \mathrm{~cm}$ long, scabrous-hairy in upper groove. Male flowers: 2-4 (of different ages) at each node (female flowers not seen), subglabrous; pedicel 25-35 mm long; expanded perianth c. $15 \mathrm{~mm}$ diam.; receptacle-tube c. 3.5 by $3 \mathrm{~mm}$, finely hairy in the throat; sepals 1-1.5 mm long; petals (6-) 7 by (3-) $4 \mathrm{~mm}$, apex subacute, inside papillose-hairy; stamens inserted about halfway the receptacle-tube, filaments 1-1.5 mm long, anthers 1.5 by $1 \mathrm{~mm}$, connective broad, at apex truncate and faintly produced in the middle; disc (depressed) globose, $1 \mathrm{~mm}$ diameter. Female flowers and fruits not known.

Distribution - Endemic to the Philippines, Luzon, Mt Data; known only from the type; flowering in September.

15. Neoachmandra morobensis (Merr. \& L.M. Perry) W.J. de Wilde \& Duyfjes, comb. nov.

Melothria morobensis Merr. \& L.M. Perry (1948) 167. - Type: M.S. Clemens 11330bis (holo MICH; iso A), Papua New Guinea, Morobe Province.

Subperennial 2-3 m long climber; stem 1-2 mm diam.; minutely hairy, glabrescent. Leaves: blade entire or 3-lobed up to halfway, broadly or narrowly triangular or subhastate, $4-10$ by $5-14 \mathrm{~cm}$, base broadly rounded, truncate or broadly emarginate with shallow sinus, apex long-acuminate, margin entire or shallowly repand-dentate, upper surface densely (appressed) grey hairy or scabrous, with or without cystoliths, lower surface sometimes less hairy, without cystoliths; with 7 palmate nerves; petiole (1.5-)2-4.5 cm long, densely harshly hairy. Male flowers: 1-4 per node, usually coaxillary with 1 female flower; pedicel $15-25 \mathrm{~mm}$ long, sparsely hairy; expanded perianth $7-9 \mathrm{~mm}$ diam.; receptacle-tube $2-2.5$ by $2.5-3 \mathrm{~mm}$, minutely papillose-hairy in the throat (hairs less than $0.1 \mathrm{~mm}$ long); sepals $1.5-2.5 \mathrm{~mm}$ long; petals $2.5-3 \mathrm{~mm}$ long, minutely hairy inside; stamens inserted at about $1 / 3$ from the apex in the receptacle- 
tube, filaments $0.5(-0.7) \mathrm{mm}$ long, anthers $1.5 \mathrm{by} 1 \mathrm{~mm}$, connective broad, at apex slightly convex or straight; disc subglobose, flattened at apex, 1 by $1.5 \mathrm{~mm}$. Female flowers: single; pedicel 12-15 mm long; ovary elongated (narrowly ellipsoid); perianth immature. Fruit solitary, narrowly ellipsoid, fusiform, 4.5-5.5(-6) by (1-) $1.5-2 \mathrm{~cm}$, base acute, apex beaked; dry pericarp coriaceous, (faintly) 6-ribbed or -lined; fruiting pedicel very slender, c. $1.5 \mathrm{~cm}$ long. Seeds numerous, $3.5-4$ by $2-2.5 \mathrm{~mm}$, with a narrow faint margin, with a short wing at base.

Field-notes - Flowers white, creamy or pale yellow; androecium orange. Fruits glaucous, pale green, darker striped.

Distribution - Endemic to Papua New Guinea: Central and Morobe Provinces.

Habitat \& Ecology - In abandoned gardens, clearings in rainforest, disturbed forest, along creeks; at 50-1300 m altitude; flowering and fruiting throughout the year.

Note - The seeds in Neoachmandra have in the dried state often a wing-like appendage, possibly formed by the fruit pulp (endocarp), but in N. morobensis this is more obvious than in other species.

Specimens examined:

Carr 14850; J. \& M.S. Clemens 1306; M.S. Clemens 11330 bis (type); Kairo \& Streimann NGF 30905; Schodde 2561; Takeuchi \& Ama 16328.

16. Neoachmandra nesophila W.J. de Wilde \& Duyfjes, spec. nov. - Plate 5c, d

Neoachmandra japonica similis fructu oblongo 2-4 $\mathrm{cm}$ longo viridi guttis fuscis in seriebus longitudinalibus distincta. - Typus: Soejatmi 10 (holo BO; iso A, K, L, SING, US), Java.

Annual or subperennial 1-3 m long climber; stem 1-1.5 mm diam.; with sparse minute hairs or glabrous. Leaves: blade ovate-triangular or (long-) triangular, $2.5-9$ by $2.5-8$ $\mathrm{cm}$, sometimes broadly hastately 3-lobed, lateral lobes to 3 by $5 \mathrm{~cm}$, base broadly rounded, truncate or widely cordate, margin entire or shallowly sparsely dentate, upper and lower surface (sub)glabrous, with or without (small) cystoliths and minute sparse hairs on the nerves; petiole 1-3(-5) cm long, subglabrous or sparsely or densely finehairy. Male flowers: 1(-3) per node, frequently co-axillary with a single female flower; pedicel 10-15 mm long, (sub) glabrous; expanded perianth 6-9 mm diam.; receptacletube $2-2.5$ by c. $2.5 \mathrm{~mm}$, outside glabrous, densely hairy in the throat (hairs $0.5 \mathrm{~mm}$ long); sepals 0.5-1 mm long; petals c. $3 \mathrm{~mm}$ long, outside glabrous or with some stout hairs, inside sparsely gland-hairy; stamens inserted close to the throat in the receptacletube, filaments $0.5 \mathrm{~mm}$ long, anthers $1-1.5 \mathrm{~mm}$ diam., exserted, connective \pm truncate and at base with a conspicuous crest-like outward protrusion of c. $1 \mathrm{~mm}$ long (always?, see note 3); disc depressed obovoid, 1-1.5 mm long. Female flowers: 1 (frequently co-axillary with male flower) or 2; pedicel usually much longer than in male, 25-45 $\mathrm{mm}$ long, (sub)glabrous; ovary narrowly ellipsoid, $8-10$ by $1.5-2(-2.5) \mathrm{mm}$, base acutish, narrowed into a slender neck $2.5-3.5 \mathrm{~mm}$ long, glabrous; receptacle-tube 2-3.5 by $2.5-3.5 \mathrm{~mm}$; style c. $2 \mathrm{~mm}$ long, stigma subglobose, c. $2 \mathrm{~mm}$ diam., 3-lobed, each lobe deeply 2-lobed, papillose; staminodes subulate, c. $1 \mathrm{~mm}$ long; disc less than $1 \mathrm{~mm}$ high. Fruit: solitary (or 2), narrowly ellipsoid, $2-4$ by $1.2-1.5 \mathrm{~cm}$, base rounded, apex \pm narrowed into an acute-acuminate c. $5 \mathrm{~mm}$ long beak; dry pericarp usually with small 
darker patches and spots arranged in longitudinal rows; fruiting pedicel $2-6 \mathrm{~cm}$ long. Seeds numerous, $3.5-4.5$ by $2-3 \mathrm{~mm}$, margin faint, at base with a short wing.

Field-notes - Flowers white. Fruits green-red or green with darker stripes or yellow.

Distribution - E Java; Philippines (Luzon, Mindoro); N Celebes; Lesser Sunda Islands (Lombok, Sumbawa, Flores, Timor (deviating, see note 1)); Moluccas (Halmahera, Banda).

Habitat \& Ecology - Damp thickets and forest edges, near streams; at low altitudes to $500(-2100) \mathrm{m}$; flowering and fruiting mainly from January to July.

Notes - 1. Two collections from Timor, Forbes $3919 \& 3957$, from c. $700 \mathrm{~m}$ altitude, deviate in the petiole and lower leaf surface, bearing rather dense and soft hairs, and in the much longer male pedicels which are 20-60 mm long. The seeds are similar to those of $N$. nesophila. More material is needed to elucidate whether we are dealing with a separate taxon.

2. Neoachmandra nesophila as it is conceived here, comprises specimens with an unusual variation in fruit size: $2-4 \mathrm{~cm}$ long. A number of specimens from the same distributional area, mostly rather incomplete, resemble $N$. nesophila but have smaller fruits, 1.5-2 cm long, without the ornamentation of fine darker-coloured patches and dots. These specimens also resemble the type and only collection of $N$. idenburgensis, from Papua, although the latter is so much different from N. nesophila that it is retained here as a distinct species. The true status of the smaller-fruited specimens alluded to above remains uncertain. A choice of these specimens is: Clemens 18282 (Luzon); Conklin \& Del Rosario PNH 72640 (Mountain Province, 2000 m); Ramos \& Edaño BS 44466 (Sulu Islands); Gaerlan PPI 23101 (Mindanao, 2110 m); De Haan 1769 (Halmahera, $20 \mathrm{~m}$ ).

3. In De Wilde \& Duyfjes 21935, in spirit, from Lombok, the connective is of a firm but watery texture and bears the described protrusion. This protrusion was not seen in boiled dried flowers in other collections. Probably the details of the connective largely got lost during the drying process.

17. Neoachmandra odorata (C.B. Clarke) W.J. de Wilde \& Duyfjes, comb. nov.

Melothria odorata C.B. Clarke (1879) 626. - Melothria leucocarpa auct. non (Blume) Cogn.: Cogn. (1881) 601, p.p; (1916) 101, p.p.; Chakrav. (1959) 151, p.p.; (1982) 82, p.p., for the Indian specimens only. - Lectotype (here chosen): Hamilton in Wallich Cat. $6706 \mathrm{~A}(\mathrm{~K}-\mathrm{W})$, India.

Melothria odorata C.B. Clarke var. triloba C.B. Clarke (1879) 626. - Melothria leucocarpa (Blume) Cogn. var. triloba (C.B. Clarke) Chakrav. (1959) 154; (1982) 83. - Lectotype (here chosen): Wallich Cat. 6707 (K-W), India.

Melothria zehnerioides Haines (1920) 315, pl. 10. - Type: Haines 4510 (holo CAL, not seen; iso $\mathrm{K})$, N India.

Distribution - India.

Notes - 1. Melothria odorata was regarded by Jeffrey (1980a) as a synonym of Zehneria indica. Both species are very close indeed. However, we consider the species as distinct, pending the study of more collections from the Indian region. The restricted material seen of $M$. odorata comprises specimens either with male or female flowers, or mixed flowers in more-flowered clusters. 
2. Melothria zehnerioides was regarded by Chakravarty $(1959,1982)$ as a synonym of Melothria odorata var. triloba. We have only seen an isotype with immature fruit. Its seeds are described as smallish, c. $3.5 \mathrm{~mm}$ long.

Specimens examined:

Haines 4510 (type); Sastry 40599.

18. Neoachmandra pentaphylla (Naudin) W.J. de Wilde \& Duyfjes, comb. nov.

Melothria pentaphylla Naudin (1862) 196. - Type: ?Pancher (P, not seen), New Caledonia, also cultivated at Paris from seeds sent by Pancher (not seen).

Distribution - New Caledonia.

Specimens examined:

Däniker 1174; Guillaumin 8611, 9496; McKee 3504.

19. Neoachmandra platysperma W.J. de Wilde \& Duyfjes, spec. nov.

Neoachmandra sphaerospermi similis, seminibus planis, pedicellis pilis eglandulosis distincta. - Typus: Phonsena, De Wilde \& Duyfjes 4015 (holo L; iso BKF), Thailand, Northern Province, Nakhon Sawan.

Tiny annual $0.5-1 \mathrm{~m}$ long climber; stem $0.5(-1) \mathrm{mm}$ diam.; (sub)glabrous, with few gland-hairs. Leaves: blade broadly ovate-triangular, $2-4$ by $3-5 \mathrm{~cm}$, base broadly rounded or truncate, apex short acute-acuminate, margin shallowly repand-dentate, teeth less than $0.5 \mathrm{~mm}$ long, minutely scabrous at both sides with few slightly stouter hairs on the nerves below; petiole $1.5-2.5 \mathrm{~cm}$ long, sparsely hairy. Male flowers: solitary; pedicel 4-5 mm long, glabrous; expanded perianth c. $3 \mathrm{~mm}$ diam.; receptacle-tube $(0.5-) 1$ by c. $1.5 \mathrm{~mm}$, outside with few minute hairs, minutely sparsely hairy in the throat; sepals $0.5 \mathrm{~mm}$ long; petals $1-1.5 \mathrm{~mm}$ long, margin and inside very finely papillose-hairy (hairs less than $1 \mathrm{~mm}$ long); stamens 2 or 3 , inserted at or slightly below halfway in the receptacle-tube, filaments $(0.2-) 0.3-0.5 \mathrm{~mm}$ long, glabrous, anthers broadly elliptic, $0.7-0.8$ by $0.6-0.7 \mathrm{~mm}$, exserted, thecae vertical and slightly curved, connective broad but \pm narrowed at apex, truncate, not produced in the middle, and with a few minute hairs; disc subglobose or faintly lobed, $0.3 \mathrm{~mm}$ diameter. Female flowers: solitary; pedicel as male, 4-5 mm long, glabrous; ovary ovoid-fusiform, $1.5-2$ by $0.8-1 \mathrm{~mm}$, base \pm narrowed, apex narrowed into a slender neck $0.5 \mathrm{~mm}$ long, glabrous; receptacle-tube 0.5 by $0.5 \mathrm{~mm}$, glabrous; style slender, $0.6 \mathrm{~mm}$ long; stigma faintly papillose, with 2 subsessile lobes, each lobe again 2- (or 3-)lobed, 0.3 mm diam.; staminodes 2 (or 3?), $0.5-0.6 \mathrm{~mm}$ long, inserted close to the base in the receptacle-tube; disc $0.2 \mathrm{~mm}$ high. Fruit solitary, globose, $0.5-0.6 \mathrm{~cm}$ diam., with a slender beak $1 \mathrm{~mm}$ long; pericarp very thin, \pm transparent, green (ultimately red?), smooth; fruiting pedicel $0.5-0.7 \mathrm{~cm}$ long. Seeds $1-3$, flat, c. 5 by $2.5 \mathrm{~mm}$, faces faintly minutely pitted, margin faint, wing absent.

Field-notes - Flowers creamy-white. Fruits glossy green.

Distribution - Thailand, Northern Province, Nakhon Sawan, Khao Than Phet; known only from the type.

Habitat \& Ecology - In blackish soil in depression of limestone, shaded; at c. $100 \mathrm{~m}$ altitude; flowering and fruiting in September. 
Notes - 1. Neoachmandra platysperma resembles $N$. sphaerosperma, both endemic species of limestone mountains in the same area. Both are small plants with extremely small flowers with 2 or 3 stamens and small globose fruits. Neoachmandra sphaerosperma differs in its conspicuous globose seeds; male and female flowers at the same node; gland-hairs all over the plant, including the pedicel; and in the articulation between pedicel and receptacle-tube $1 \mathrm{~mm}$ below the tube.

2. Neoachmandra platysperma is aberrant within the genus Neoachmandra because of the insertion of the stamens, somewhat below halfway the receptacle-tube, and of the shape of the anthers; the ovary contains only 2 or 3 ovules.

20. Neoachmandra samoensis (A. Gray) W.J. de Wilde \& Duyfjes, comb. nov.

Melothria samoensis A. Gray (1854) 641. - Zehneria samoensis (A. Gray) Fosberg \& Sachet (1981) 12. - Lectotype (Fosberg \& Sachet, 1981): US Exploring Expedition s.n. (US, not seen), Samoa, without further locality.

Melothria rechingeri Cogn. (1908) 257. - Lectotype (here chosen): K. \& L. Rechinger 5244 (W), Samoa, Savaii Islands.

Field-note - Fruits red.

Distribution - Samoa; New Caledonia (1 collection).

Habitat \& Ecology - Flowering and fruiting in July.

Specimens examined:

Guillaumin 10046, 10500 (New Caledonia); K. \& L. Rechinger 660, 1035, 1601, 1629, 5244 (lectotype); Reinecke 64, 398; Setchell 290; Sykes 503 (Niue Island); Yuncker 15877.

21. Neoachmandra scaberrima (Merr.) W.J. de Wilde \& Duyfjes, comb. nov.

Melothria scaberrima Merr. (1909) 330. - Lectotype (here chosen): Elmer 5862 (L; iso BO, K, $\mathrm{PNH} \dagger$ ), Philippines, Luzon, Benguet.

Annual or subperennial 1-3 m long climber; stem 1-1.5 mm diam.; with sparse hairs, glabrescent. Leaves: blade narrowly triangular or sublanceolate, 4-10 cm long, unlobed, or base short or long hastately lobed (see also the note), basal lobes up to 5 by $1 \mathrm{~cm}$, base (sub)truncate, apex (long-)acute, margin entire, minutely sparsely denticulate, upper surface scabrous by dense coarse appressed hairs, with or without cystoliths, lower surface less densely hairy, but on the nerves with conspicuous grey bristly patent hairs $0.5-1.5 \mathrm{~mm}$ long, rarely shorter; petiole $1-2.5 \mathrm{~cm}$ long, shortly scabrid or harshly hairy. Male flowers: 1 or 2 per node, frequently co-axillary with 1 much longer-pedicelled female flower; pedicel 8-10 mm long, with scattered $0.2-0.3 \mathrm{~mm}$ long hairs; expanded perianth 6-7 $\mathrm{mm}$ diam.; receptacle-tube c. 2 by $2 \mathrm{~mm}$, outside with few hairs, minutely hairy in the throat; sepals $0.5 \mathrm{~mm}$ long; petals $2-2.5 \mathrm{~mm}$ long, outside frequently with few hairs, inside densely glandular-hairy; stamens inserted at c. 1/4 from the apex in the receptacle-tube, filaments $0.5 \mathrm{~mm}$ long, anthers 1.5 by $1 \mathrm{~mm}$, connective truncate, with short mucro in the middle; disc subglobose, 1-1.5 mm diameter. Female flowers: 1 (and then frequently co-axillary with male flower) or 2 per node, larger than male flowers; pedicel 20-40 mm long, sparsely hairy, glabrescent; ovary narrowly ellipsoid, $5-7(-10)$ by $1-1.5(-2.5) \mathrm{mm}$, gradually narrowed into a slender neck c. $2 \mathrm{~mm}$ long, sparsely hairy; receptacle-tube $3-3.5$ by $3-3.5 \mathrm{~mm}$; sepals $1 \mathrm{~mm}$ long; petals $2.5-4$ 
$\mathrm{mm}$ long; style c. $3 \mathrm{~mm}$ long, with 3 short arms each bearing a subglobose pillose-hairy stigma of c. $1.5 \mathrm{~mm}$ diam.; staminodes $0.5-1 \mathrm{~mm}$ long; disc $1 \mathrm{~mm}$ high, \pm 3 -lobed or not. Fruit solitary (or 2), (narrowly) ellipsoid, $3-3.5$ by $1.5-2 \mathrm{~cm}$, base shortly acute or subobtuse, apex acute or up to $0.5 \mathrm{~cm}$ beaked; dry pericarp faintly 6-lined near apex; fruiting pedicel $2-4.5 \mathrm{~cm}$ long. Seeds numerous, $4-5$ by $2.5-3.5 \mathrm{~mm}$, margin faint, at base with a short wing.

Field-notes - Flowers white. Fruits green, yellow when ripe.

Distribution - Endemic to the Philippines: Luzon (Benguet, Rizal); one deviating collection from Mindanao (see note).

Habitat \& Ecology - Thickets, shrubbery, along streams, grassy roadsides; at 300-1000 $\mathrm{m}$ altitude; flowering and fruiting throughout the year.

Note - Two deviating specimens are: Ramos BS 14608, the only collection from Mindanao, and Loher 2136, from Central Luzon. Ramos BS 14608 deviates in having broader triangular or 3-5-lobed leaves, and Loher 2136 in having narrow, hastate leaves with the nerves only shortly scabrous hairy, short female pedicels, only 5-10 $\mathrm{mm}$ long, and smaller fruits, only c. $2 \mathrm{~cm}$ long. The latter is likely to be a local variety, or both may belong to the specimens discussed under $N$. nesophila (see there).

22. Neoachmandra sphaerosperma (W.J. de Wilde \& Duyfjes) W.J. de Wilde \& Duyfjes, comb. nov. - Fig. 7; Plate 6a, b

Zehneria sphaerosperma W.J. de Wilde \& Duyfjes (2004) 24, f. 3. - Type: Pooma, W.J. de Wilde, Duyfjes, Chamchumroon \& Phattarahirankanok 3043 (holo BKF; iso L), Thailand, Saraburi.

Annual tiny slender climber, c. $1 \mathrm{~m}$ long; young parts with fine gland hairs, early glabrescent. Leaves: blade triangular, 3.5-5 cm long and broad, base subtruncate, shallowly retuse, apex acute-acuminate, margin shallowly repand-dentate, above with small cystoliths, nerves sparsely scabrous-hairy below; petiole 1-3 cm long, sparsely hairy. Flowers minute, petals 4 or 5, (sub)valvate-imbricate. Male flowers: single, co-axillary with single female flower; pedicel 2-4 $\mathrm{mm}$ long, the portion below the articulation sparsely glandular-hairy; open perianth $2-2.5 \mathrm{~mm}$ diam.; receptacle-tube c. 1 by 1.5 $\mathrm{mm}$, inside finely hairy at the throat; sepals $0.5-0.7 \mathrm{~mm}$ long, slightly out-curved; petals 1-1.2 $\mathrm{mm}$ long, subobtuse, with a few hairs on the margin and inside papillose; stamens ( 2 or) 3 , inserted about level with the apex of the disc, filaments slender, slightly shorter than the anthers, $0.4-0.6 \mathrm{~mm}$ long, anthers 0.8 by $0.6 \mathrm{~mm}$, connective at apex truncate or slightly produced; disc comparatively large, \pm obovoid-globose, $0.5-0.7$ $\mathrm{mm}$ diameter. Female flowers: solitary or co-axillary with male; pedicel c. $3 \mathrm{~mm}$ long; ovary subglobose-ellipsoid, c. 2.5 by $(1.5-) 1.7 \mathrm{~mm}$, glabrous, very finely papillose, neck $0.5 \mathrm{~mm}$ long; ovules 3 , enclosed in watery pulp; receptacle-tube 0.8 by $0.8 \mathrm{~mm}$; sepals c. $0.3 \mathrm{~mm}$ long; petals c. 1.2 by $0.7 \mathrm{~mm}$; style $0.8 \mathrm{~mm}$ long, stigma $0.5 \mathrm{~mm}$ across, consisting of 3 subsessile papillose-hairy lobes; staminodes narrowly elliptic or spathulate, $0.3-0.4$ by $0.2 \mathrm{~mm}$, inserted towards the base of the receptacle-tube; disc conspicuous, 0.3 by $0.6-0.7 \mathrm{~mm}$, faintly 3-lobed. Fruit solitary, depressed globose, 5-7 mm diam., not or very shortly narrowly beaked, glabrous; pericarp membranous, smooth; fruiting pedicel $0.3-0.4 \mathrm{~cm}$ long. Seeds 1 or 2 , enclosed in little watery pulp, (sub) globose, 3.5-4 mm diam., smooth, with distinct equatorial ridge, faces hemiglobose swollen, at base sagged. 

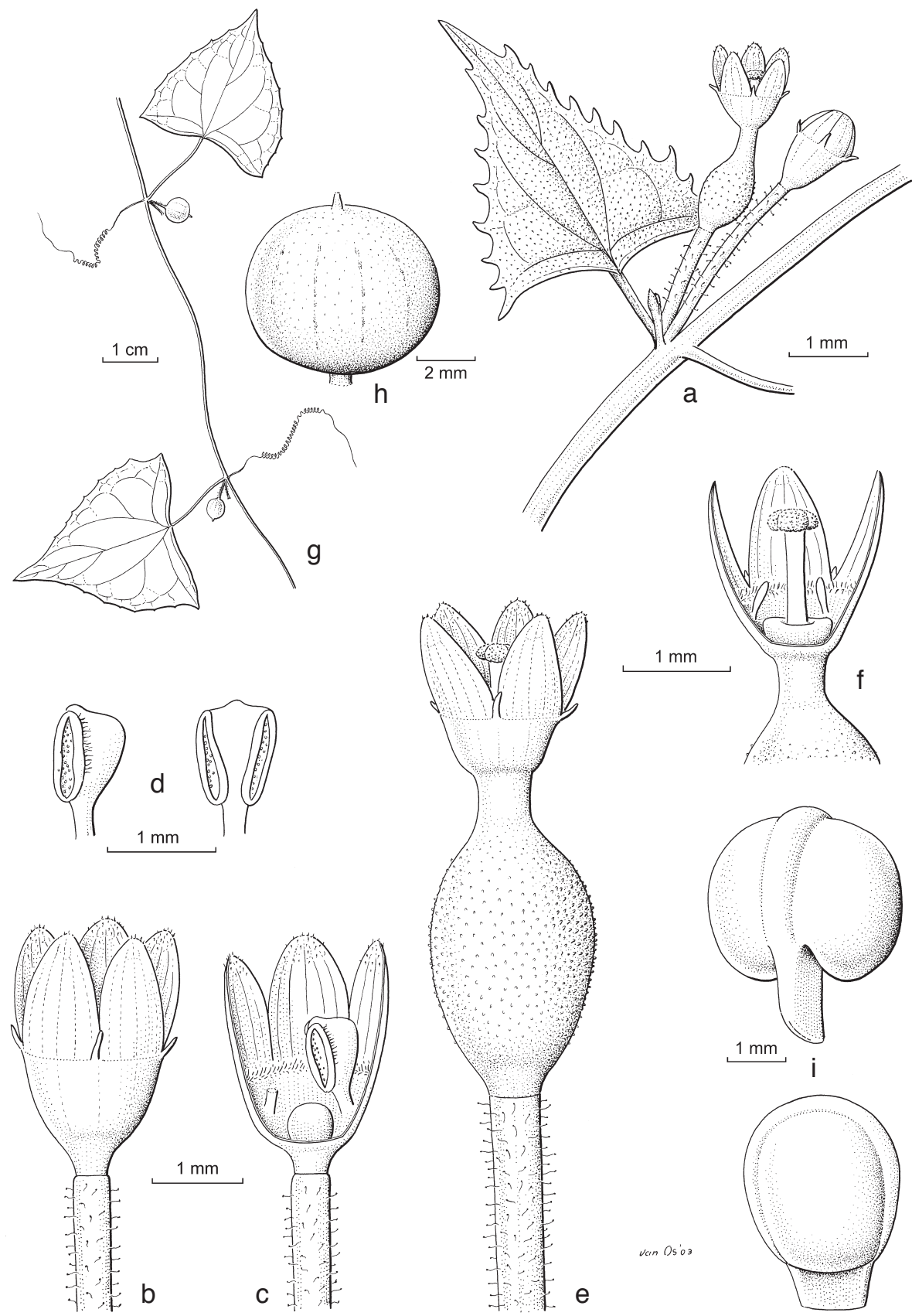

Fig. 7. Neoachmandra sphaerosperma (W.J. de Wilde \& Duyfjes) W.J. de Wilde \& Duyfjes. a. Habit of flowering node; b, c. male flowers; d. stamens; e, f. female flowers; g. portion of stem with fruits; h. fruit; i. seeds (all: Pooma c.s. 3043, type). 
Field-notes - Fruits bright red when ripe and \pm juicy with big creamy-white seeds, which are carried away into crevices by dark-brown ants, obviously facilitating local dispersal.

Distribution - Locally endemic to Thailand, c 100 km north of Bangkok.

Habitat \& Ecology - Trailing in light shade over eroded limestone rock; 100$350 \mathrm{~m}$ altitude; flowering and fruiting: August and October.

Note - Neoachmandra sphaerosperma is distinct from other species by gland-hairs, very small 4- or 5-merous flowers, only 2 (or 3) stamens, a reduced number of ovules and seeds, and comparatively large seeds with conspicuously swollen faces rendering these large and globose. The aestivation is difficult to ascertain due to the very small dimensions of the corolla lobes. See also N. platysperma.

Specimens examined:

Mitsuta et al. T 38223; Pooma et al. 2990; 3043 (type); Smitinand \& Sleumer 1339.

23. Neoachmandra wallichii (C.B. Clarke) W.J. de Wilde \& Duyfjes, comb. nov.

- Fig. 8; Plate 6c, d

Zehneria wallichii (C.B. Clarke) C. Jeffrey (1980a) 18; (1980b) 802; A.M. Lu \& Zhi Y. Zhang (1986) 172; S.K. Chen (1995) 317; W.J. de Wilde \& Duyfjes (2004) 27. - Melothria wallichii C.B. Clarke (1879) 626; Cogn. (1881) 592; (1916) 91; Chakrav. (1959) 156, f. 71. - Type: Wallich Cat. $6706 D(\mathrm{~K}-\mathrm{W})$, Myanmar, Prome.

Annual slender 1-4 m long climber; finely soft pale gland-hairy and with hairs 1-2 mm long, later glabrescent. Leaves: blade (sub)triangular, $4-11$ by $3.5-10 \mathrm{~cm}$, base truncate or very shallowly retuse, apex acute-acuminate, margin straight or faintly undulating, teeth minute, older leaves densely covered with cystoliths above, nerves \pm patently hairy below; petiole 1-6 cm long, \pm harshly whitish hairy. Male flowers: solitary and long-pedicelled, or co-axillary with a solitary, slightly later developing, female flower, on the nodes of the leafy stem, or male flowers slightly shorter-pedicelled and arranged in loose short-shoots to $5 \mathrm{~cm}$ long and sprouting from the nodes; pedicel $10-20 \mathrm{~mm}$ long, sparsely pale hairy; open perianth c. $7 \mathrm{~mm}$ diam.; receptacle-tube \pm narrowly cup-shaped, c. 2.5 by $2 \mathrm{~mm}$, glabrous but inside at throat densely finely long-haired, 0.5 $\mathrm{mm}$ long; sepals c. $1 \mathrm{~mm}$ long; petals $3-3.5$ by $2-2.5 \mathrm{~mm}$, obtuse or subacute, inside and at apex papillose and gland-hairy; stamens 3, inserted slightly below the apex of the tube, filaments $0.8-1 \mathrm{~mm}$ long, glabrous, anthers 1.2 by $0.7 \mathrm{~mm}, \pm$ obtriangular, thecae straight, $1 \mathrm{~mm}$ long, connective broad, widening towards apex, slightly produced; disc obovoid, $1-1.2$ by $0.6-0.7 \mathrm{~mm}$. Female flowers: pedicel $5-8 \mathrm{~mm}$ long; ovary narrowly fusiform, (10-)20-30 by (1-)2-3 mm, long-tapering towards apex into a narrow $1 \mathrm{~mm}$ long neck, glabrous (except for some very fine papillae); perianth as in male flower; style c. $3 \mathrm{~mm}$ long, stigma consisting of 3 deeply notched papillose lobes, together c. $1.5 \mathrm{~mm}$ diam.; staminodes 3 , linear, $1 \mathrm{~mm}$ long, inserted halfway the receptacle-tube; disc carnose, nearly $1 \mathrm{~mm}$ high. Fruit narrowly elliptic (fusiform), 4-6 by c. $1 \mathrm{~cm}$, base and apex on drying narrowed into slender c. $1.5 \mathrm{~cm}$ long beaks; fruiting pedicel 1-2 cm long. Seeds many, flat, c. 5 by $3 \mathrm{~mm}$, smooth, margin faint.

Field-note - Fruits pale green and dark green striped.

Distribution - E Myanmar and northern Thailand; also reported for China (Yunnan) but no material seen. 


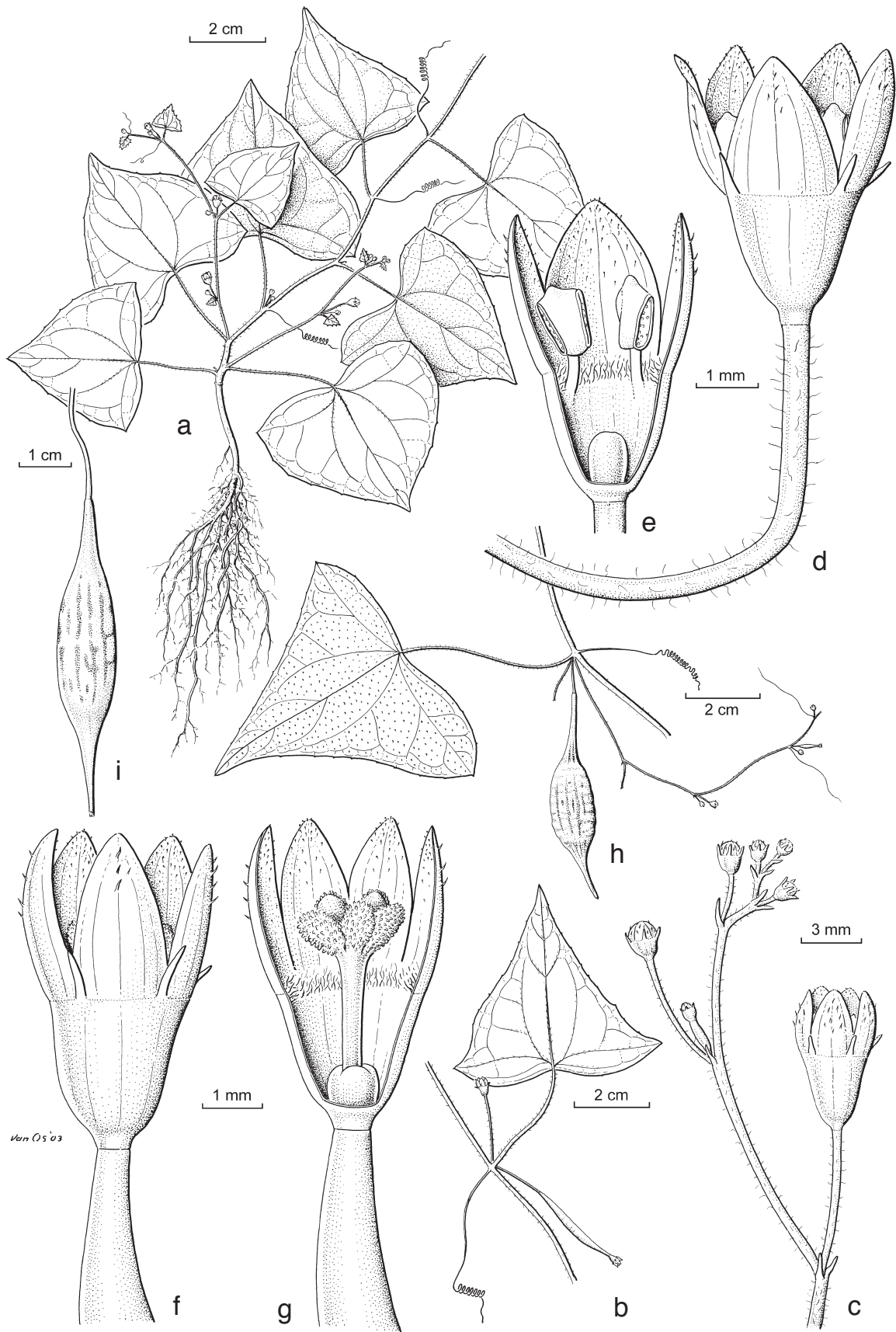

Fig. 8. Neoachmandra wallichii (C.B. Clarke) W.J. de Wilde \& Duyfjes. a. Habit of base of plant; b. node of older plant with male and female flower; c. tip of flowering lateral twig; d, e. male flowers; f, g. female flowers; h. node with fruit and flowering lateral twig; i. fruit (from alcohol material) (a: Maxwell 90-799; b-i: De Wilde \& Duyfjes 22149). 
Habitat \& Ecology - (Open deciduous) forest; gullies, damp shaded sites; on granitic, shale, or limestone bedrock; at 200-1500 m altitude; flowering and fruiting (June) July to October.

\section{SCOPELLA - Fig. 1b, 2d; Table 1}

Scopella W.J. de Wilde \& Duyfjes, gen. nov.

A Zehneria probractea absenti differt; folia viridia in sicco; petala lutea imbricata in alabastro; stamina in tubi receptaculi fauce inserta; filamenta longa tenuia; stigmatis lobi elongati marginibus laciniatis; semina scrobiculata. - Typus: Scopella marginata (Blume) W.J. de Wilde \& Duyfjes.

Small or medium climbers to $6 \mathrm{~m}$ long, annual or (sub)perennial; monoecious; green on drying. Probract absent. Tendrils simple, hairy (see note). Leaves simple, entire or lobed, palminerved. Flowers small- or medium-sized, 5-10 mm diam., yellow; sepals minute, narrowly elliptic or linear, subpatent; petals free, (ob)ovate-elliptic, imbricate in bud; receptacle-tube campanulate. Male inflorescence: $1(-3)$ slender peduncled short raceme(s) with the flowers crowded, co-axillary with 1 (or 2) female flower(s) or not. Bracts absent. Male flowers: pedicel c. $5 \mathrm{~mm}$ long, persistent; stamens 3, exserted, inserted in the throat of the receptacle-tube, erect, filaments long, longer than the anther; anthers all 2-thecous, thecae lateral, straight, connective narrow, not produced; disc free, (depressed-)globose. Female flowers 1 or 2, co-axillary with peduncle of male inflorescence or not; pedicel long; ovary globose or ellipsoid, without slender neck, sparsely hairy; stigma consisting of 3 flat lobes, fringed on the margin; staminodes present; disc annular, free from receptacle-tube. Fruit 1 (or 2), with short or long fruiting pedicel, globose, ellipsoid, or narrowly ellipsoid (fusiform), small, 1-1.5(-3) cm long, red, juicy or pulpy; pericarp filmy, membranous or cartilaginous, smooth. Seeds numerous, moderately compressed, ovate-elliptic, faces \pm convex, scrobiculate, margin distinct, unwinged.

A genus with 2 species ranging from S China through Indo-China to W Malesia (Celebes, Philippines); not known from Myanmar and Taiwan.

Note - In Scopella the tendrils are completely hairy (although sometimes sparingly so); in related genera the tendrils are glabrous or hairy only below the first spiral.

\section{KEY TO THE SPECIES OF SCOPELLA}

1a. Leaves coriaceous, with hard-spiny edge. Seeds 7(-8) mm long. - Borneo

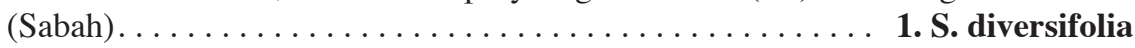

b. Leaves membranous or chartaceous, edge denticulate. Seeds $2.5-6 \mathrm{~mm}$ long. - Widespread

1. Scopella diversifolia (Merr.) W.J. de Wilde \& Duyfjes, comb. nov.

Melothria diversifolia Merr. (1923) 44. - Type: Ramos 1896 (holo $\mathrm{PNH} \dagger$; lecto (here chosen): BO, iso UC), Sabah, near Sandakan.

Subherbaceous 2-6 m long climber; stem 1.5-3 mm diam., glabrescent. Leaves: blade (sub)coriaceous, narrowly ovate to narrowly elliptic, 7-14(-20) by $2-8(-12) \mathrm{cm}$, base 
truncate, shallowly cordate or sagittate with acute lobes to $1.5 \mathrm{~cm}$ long, margin entire or faintly dentate with sparse, small but coarse $1 \mathrm{~mm}$ long hard teeth, upper surface coarsely scabrous by conspicuous (white) cystoliths, lower surface subglabrous; petiole 1-2(-4) cm long, short scabrid-hairy, hairs $0.5 \mathrm{~mm}$ long. Male inflorescences solitary, peduncle $2-3.5 \mathrm{~cm}$ long, subglabrous, raceme short, rarely 2-branched, with $5(-10)$ flowers; male pedicels 1-2(-5) mm long, female pedicel 1-2 cm long. Mature male and female flowers not seen (see note), presumably similar to $S$. marginata: anthers c. $1.5 \mathrm{~mm}$ long; ovary ovoid, c. $3 \mathrm{~mm}$ long; sepals lanceolate, c. $1.5 \mathrm{~mm}$ long; petals ovate-elliptic, acuminate, c. $5 \mathrm{~mm}$ long; staminodes $1.2 \mathrm{~mm}$ long; stigma-lobes deeply cleft, c. $2 \mathrm{~mm}$ long. Fruit solitary or co-axillary with (previously) developed male inflorescence, globose, 1-1.5 cm diam.; pericarp cartilaginous, glabrous, brown-yellow when dry; fruiting pedicel $2-4.5 \mathrm{~cm}$ long, subglabrous. Seeds numerous, flat, elliptic or obovate, base narrowed, $6-8$ by $4-4.5$ by $1-1.5 \mathrm{~mm}$, pale yellowish brown, faces almost smooth or indistinctly scrobiculate, margin narrow but distinct.

Field-notes - Petals yellow. Fruits red.

Distribution - Borneo: C and E Sabah.

Habitat \& Ecology - In thickets and forest edges; at 0-250 m altitude; flowering and fruiting throughout the year.

Note - According to Merrill (1923: 44) who examined Ramos 1175, 1210, 1896 (material now partly lost), the male flowers are similar to female flowers; the flower details given are his.

2. Scopella marginata (Blume) W.J. de Wilde \& Duyfjes, comb. nov. - Fig. 9; Plate $7 \mathrm{a}, \mathrm{b}$

Bryonia marginata Blume (1826) 924. For further synonyms and references, see under the varieties.

Annual or biennial, (sub)herbaceous, creeping or climbing, (0.5-)1-5 m long, variously scabrid-hairy; stem 1-2 mm thick; glabrescent. Leaves: blade variable in shape, (long) triangular, ovate, or cordiform, 4-16 by 3-10 cm, entire or shallowly or deeply (hastately) 3- or 5-lobed, base truncate, rounded, or (deeply) cordate, apex acuteacuminate, margin entire with minute teeth or dentate, upper surface rough-hairy and/or scabrous by (coarse) cystoliths, lower surface coarsely hairy mostly only on the nerves; petiole 1-5 cm long, with soft or coarse $0.5-1(-2) \mathrm{mm}$ long hairs. Male inflorescences $1(-3)$, glabrescent, usually co-axillary with 1 (or 2) previously developed female flower(s); peduncle $1.5-6 \mathrm{~cm}$ long, $0.5 \mathrm{~mm}$ thick; raceme $0.3-1(-2) \mathrm{cm}$ long, (3-)5-10(-25)-flowered; pedicels half-patent, persistent. Male flowers: pedicel 2-7 mm long; receptacle-tube 1.5-2 mm diam., sparsely coarsely hairy outside, throat hairy; sepals patent or \pm out-curved, $1 \mathrm{~mm}$ long, with sparse hairs; petals (2-)3-4 by $2.5-3$ $\mathrm{mm}$, rounded or (sub)obtuse-acuminate, (papillose) hairy; filaments 1-1.5 mm long, glabrous, anthers ellipsoid, $1 \mathrm{~mm}$ long, thecae $1 \mathrm{~mm}$ long; disc $1 \mathrm{~mm}$ diameter. Female flowers: pedicel 5-30 mm long; ovary ellipsoid, 3-5 $\mathrm{mm}$ long, with sparse hairs, subglabrescent; receptacle-tube shallow; perianth as in male flower but petals larger, 4-5 mm long; style c. $2 \mathrm{~mm}$ long, glabrous; stigma consisting of 3 feather-like arms, shallowly forked at apex, each c. $2 \mathrm{~mm}$ long; staminodes linear, $1 \mathrm{~mm}$ long, inserted at the base of the receptacle-tube; disc less than $1 \mathrm{~mm}$ high. Fruit (remarkably variable in shape and texture, see note under var. marginata), either globose or ellipsoid, 1-1.5 $\mathrm{cm}$ long with base and apex rounded, or fruits narrowly ellipsoid, tapering at base and 


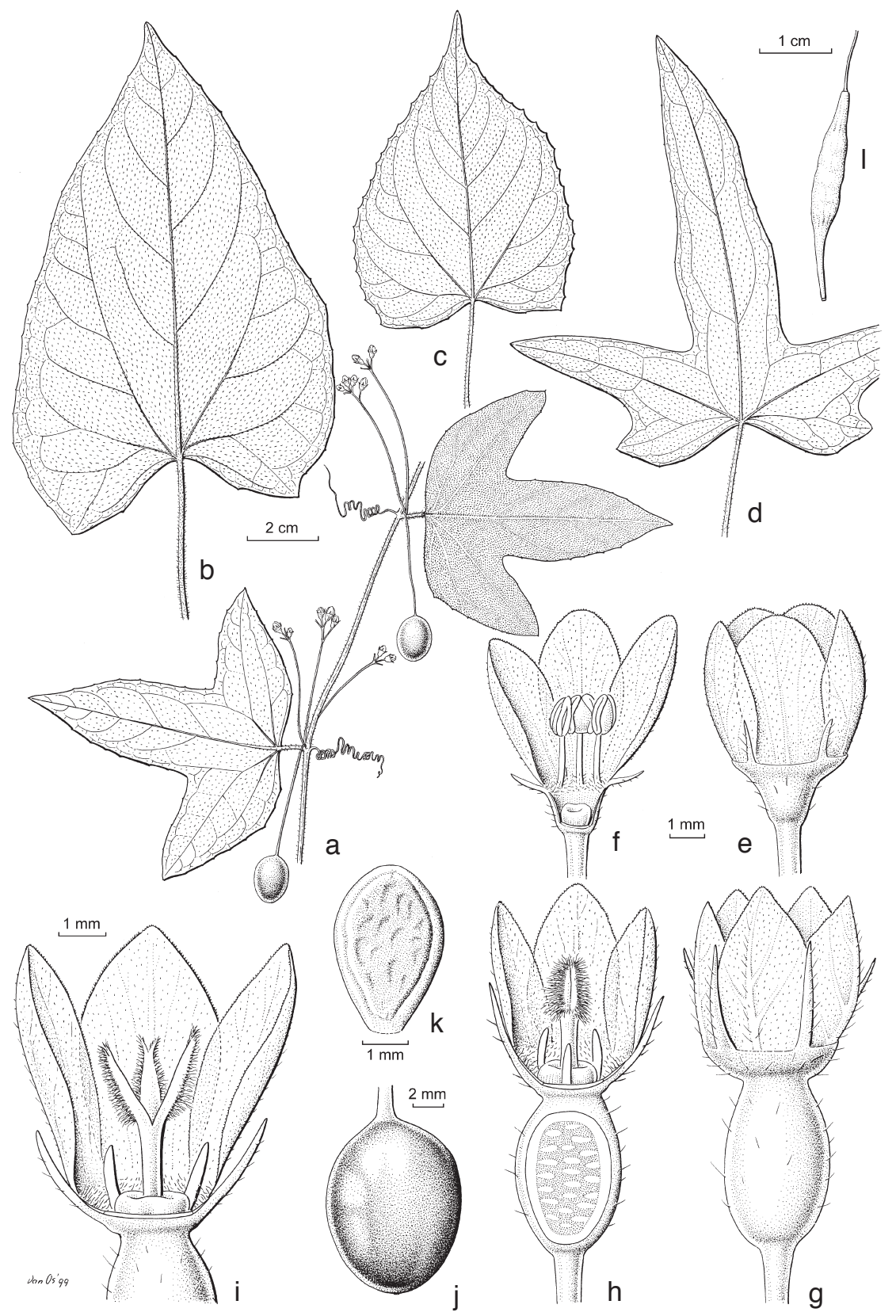

Fig. 9. Scopella marginata (Blume) W.J. de Wilde \& Duyfjes var. marginata. a. Habit; b, c, d. leaves; e, f. male flowers; g, h, i: female flowers, from outside, opened, and with expanded stigma, respectively; j. fruit (informal form 'affinis'); k. seed; 1. fruit (informal form 'marginata) (a: Awong Kaya s.n., barcode L0130026 (Brunei); b: De Wilde \& Duyfjes 12614 (Sumatra); c: De Wilde \& Duyfjes 21794 (Sumatra); d: Iwatsuki c.s. 1732 (Sumatra); e-j: De Wilde \& Duyfjes 21756 (Celebes); k: De Wilde \& Duyfjes 21699 (Java); 1: De Wilde \& Duyfjes 22182 (Thailand)). 
apex, $1.5-2(-3)$ by c. $0.5 \mathrm{~cm}$, glabrescent; pericarp membranous or \pm leathery, leaving the seeds visible or not on drying; ripe fruits juicy or with yellowish pulp; fruiting pedicel short or long, (0.5-)1-5 cm long (short when fruit narrowly ellipsoid). Seeds $5-35$ per fruit, whitish, flat or faces \pm convex, narrowly ovate, $3-5(-6)$ by $1.5-3.5$ by c. $1.5 \mathrm{~mm}$, distinctly square-margined, faces (deeply) finely or coarsely scrobiculate.

Distribution - E Myanmar (Wallich Cat. 6713, only photo seen), China (Yunnan, no material seen), through Thailand, Laos, Cambodia, Viêt-Nam to Sumatra, Peninsular Malaysia, Borneo (mainly Sabah), W Java, Philippines, and C Celebes.

Habitat \& Ecology - Open and shaded places, mostly in forest edges, roadsides; at $0-1500 \mathrm{~m}$ altitude; flowering and fruiting mostly June to December.

Notes - 1. Both Cogniaux (1881) and King (1898) described the fruits as velvety, but this aspect obviously is caused by drying; in fact the fruits are early glabrescent.

2. King (1898) described the tendril erroneously as bifid.

\section{KEY TO THE VARIETIES}

1a. Leaf blade entire, narrowly ovate, base cordate or short-sagittate. Seeds 4-5(-6) mm long . . . . . . . . . . par. penangense

b. Leaf blade subentire, or shallowly or deeply 3(-5)-lobed, ovate or triangular, base rounded, cordate or hastate. Seeds $2.5-4 \mathrm{~mm}$ long. . . . . . . a. var. marginata

\section{a. var. marginata}

Bryonia marginata Blume (1826) 924; Ser. (1828) 305; M. Roem. (1846) 36; Miq. (1856) 660. - Melothria marginata (Blume) Cogn. (1881) 593; (1916) 93; Backer (1964) 296. - Zehneria marginata (Blume) Keraudren (1975b) 55, pl. 9: 4; A.M. Lu \& Zhi Y. Zhang (1986) 172; S.K. Chen (1995) 316; W.J. de Wilde \& Duyfjes (2004) 21, f. 2. - Type: Blume 920 (holo L), Java. Bryonia epigaea auct. non Rottl.: Blume (1826) 925. - Aechmandra blumeana M. Roem. (1846) 33, p.p; Miq. (1856) 657, p.p. (a new name for Bryonia epigaea auct. non Rottl.: Blume (Bryonia exigua Blume, in sched.)). - Type: Blume s.n., barcode L0130057 (holo L; iso L, 3 sheets), Java.

?Cerasiocarpum maingayi C.B. Clarke (1879) 629. - Type: Maingay 1268 (holo K), Peninsular Malaysia. (Male flower with reduced androecium; see note.)

Melothria affinis King (1898) 38; Cogn. (1916) 94. - Lectotype (here chosen): Scortechini 495

(K), Peninsular Malaysia, Perak.

Melothria gracilipes Merr. (1934) 199. - Type: Bartlett 7228 (holo NY; iso MICH), Sumatra.

Climber 0.5-3 m long. Leaves usually angular or lobed. Fruit globose, ellipsoid or long-fusiform. Seeds few or numerous, small, 2.5-4 mm long, the faces flat or somewhat convex, coarsely scrobiculate.

Distribution - As the species.

Note - Apart from a variable habit of the plant, mainly due to variation in leaf-shape and indumentum, the variety marginata exhibits a remarkable variation in fruit-shape and length of fruiting pedicel. Most specimens have globose fruits with long pedicels, some have (narrowly) ellipsoid-fusiform fruits with short pedicels. Although most herbarium specimens have a constant fruit form, there are several collections indicating that both forms may occur in one plant. The type-specimen of the present species is the less frequent form with the slender fusiform fruits. The form with elongate, fusiform fruits with comparatively small male flowers, often with reduced petals and stamens, may be related to small plants from poor soils that flower precociously. 


\section{KEY TO THE INFORMAL FORMS}

2a. Fruit short-ellipsoid or globose $\ldots \ldots \ldots \ldots \ldots \ldots$ informal form 'affinis'

b. Fruit (narrowly) ellipsoid, \pm fusiform . . . . . . . . . informal form 'marginata'

Informal form 'marginata' - Fig. 91

Fruits narrow, ellipsoid, \pm fusiform, $1.5-3$ by c. $0.5 \mathrm{~cm}$, base (sub) acute, apex narrowly obtuse, acute-acuminate, or rostrate, juicy when ripe; fruiting pedicel shorter than the fruit, c. $0.5 \mathrm{~cm}$ long. Seeds (1-)5-12 per fruit.

Distribution - As the species.

Note - The informal form 'marginata' represents the type (Blume 920, in L) of the oldest available name.

Informal form 'affinis' - Fig. 9j

Fruits globose or (short-)ellipsoid, $0.8-1.5 \mathrm{~cm}$ diam., base and apex obtuse or (broadly) rounded, pulpy or juicy when ripe; fruiting pedicel usually longer than the fruit, 1-5 cm long. Seeds 20-30 per fruit.

Distribution - As the species; it is the commonest form.

b. var. penangense (C.B. Clarke) W.J. de Wilde \& Duyfjes, comb. \& stat. nov.

?Cerasiocarpum penangense C.B. Clarke (1879) 629. - Bryonia heterophylla auct. non Blume: Wallich Cat. 6704. - Type: Wallich Cat. 6704 (K-W), Peninsular Malaysia, Penang.

Bryonia filicaulis Wall., nom. nud. - Voucher specimen: Wallich Cat. 6713 (see note 2).

Climber 1-5 m long. Leaves entire, ovate or narrowly ovate, base sometimes sagittate. Fruit short-ellipsoid or globose, 1-1.5 cm long. Seeds numerous, 4-5(-6) mm long, the faces flat, finely scrobiculate.

Distribution - In the western half of the species area where it occurs beside the type-variety: S China, Thailand, Laos, Viêt-Nam, Cambodia, Sumatra and Peninsular Malaysia.

Notes -1 . Specimens from Thailand have somewhat bigger seeds (c. $5 \mathrm{~mm}$ long) compared to those from Sumatra (c. $4 \mathrm{~mm}$ long). The specimen Sanan 471 (BKF) from Thailand, Surat Thani, is of a stout habit, with large seeds, $6 \mathrm{~mm}$ long. It approaches S. diversifolia from Sabah.

2. The specimen Wallich Cat. 6713 (photo seen only) is mentioned under Kedrostis (Rhynchocarpa) by various previous authors; it is the only collection from Myanmar known to us which may represent the present species.

\section{URCEODISCUS - Fig. 1b, 2e; Table 1}

Urceodiscus W.J. de Wilde \& Duyfjes, gen. nov.

A Zehneria probractea absenti differt; folia viridia in sicco; petala viridia imbricata in alabastro; stamina in tubi receptaculi fauce inserta; filamenta longa tenuia, connectivo lato vel angustato; discus tubi receptaculi basi connatus; stigmatis lobi elongati; semina tumida scrobiculata emarginata. - Typus: Urceodiscus belensis (Merr. \& L.M. Perry) W.J. de Wilde \& Duyfjes. 
Small annual or subperennial climbers; monoecious; green on drying. Probract absent. Tendrils simple. Leaves simple, entire or lobed. Flowers small or medium, 5-20 mm diam., (green-)yellow; sepals minute, narrowly triangular, patent; petals free or up to $1 / 3$ connate, (sub)elliptic, the segments imbricate in bud; receptacle-tube urceolate or campanulate; disc in both sexes urceolate, thick-carnose, wholly or largely fused with the base of the receptacle-tube. Male inflorescence: a peduncled raceme, with flowers arranged zigzag or not, without or with co-axillary a solitary male or female flower. Bracts absent or minute. Male flowers: pedicel short or long, 2-20(-30) mm long, persistent; stamens 3, inserted at c. $1 / 3$ below the throat of the receptacle-tube, filaments much longer than the anther, anthers all 2-thecous, \pm exserted, thecae sublateral, straight (or \pm curved), parallel or \pm divergent, connective narrow, or broad and then at apex broad and produced or not. Female flower solitary, single at the node or co-axillary with male raceme; pedicel long; ovary subglobose or short-ellipsoid or fusiform, with a narrow neck, glabrous; stigma deeply 3-lobed, papillose-hairy; staminodes present; disc more shallow than in male. Fruit solitary, with long fruiting pedicel, globose or ellipsoid, $0.8-3 \mathrm{~cm}$ long, glabrous, not beaked, red, juicy; pericarp \pm membranous, translucent (showing the seeds), minutely pustulate. Seeds c. 10 or numerous, little compressed or almost spherical, ovoid, finely but conspicuously scrobiculate, margin faint or narrow, unwinged.

A genus of 7 species confined to New Guinea.

Note - The species much resemble each other vegetatively, but they are distinct by characters of the male inflorescences and male flowers.

\section{KEY TO THE SPECIES OF URCEODISCUS}

1a. Male pedicels $1-3 \mathrm{~mm}$ long; rachis usually straight $\ldots \ldots \ldots \ldots \ldots \ldots 2$

b. Male pedicels $5 \mathrm{~mm}$ long or more; rachis frequently zigzag. [Male inflorescences

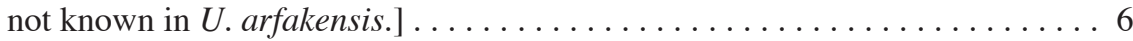

2a. Male perianth 5-6 mm long; filaments hairy, in-curved at apex. Leaves lobed to $1 / 3$ to nearly to the base $\ldots \ldots \ldots \ldots \ldots \ldots \ldots \ldots \ldots \ldots \ldots$. U. scabridula

b. Male perianth 5-15 mm long; filaments glabrous, straight. Leaves finely or coarsely

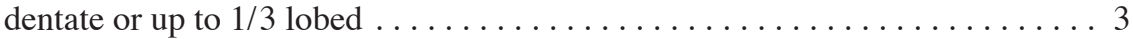

3a. Male receptacle-tube shorter than broad or about as long as broad, 2-3 $\mathrm{mm}$ long

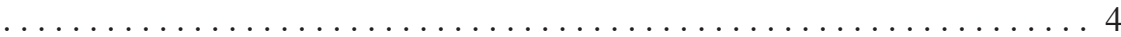

b. Male receptacle-tube longer than broad, c. $4 \mathrm{~mm}$ long. [Fruit not known.] Vogelkop; lowland . . . . . . . . . . . . . . . . . . 7. U. viridis

4a. Male petals $10 \mathrm{~mm}$ long or more......... 2. U. belensis var. conferta

b. Male petals $6-9 \mathrm{~mm}$ long . . . . . . . . . . . . . . . 5

5a. Male perianth c. $6 \mathrm{~mm}$ diameter. - E Papua New Guinea; at c. $2000 \mathrm{~m}$ altitude

3. U. carrii

b. Male perianth c. $4 \mathrm{~mm}$ diameter. - N Papua, Cycloop Mountains; at c. $1200 \mathrm{~m}$ altitude .................... p. parviflora

6a. Fruit 2-3 cm long (flowers not known). - Papua, Arfak Mountains; at $850 \mathrm{~m}$

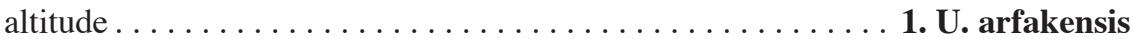

b. Fruit 1-1.5(-2) cm long (fruit not known in U. hippocrepicus). Flowers large,

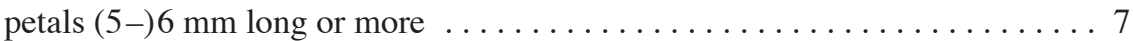


7a. Receptacle-tube inside and filaments glabrous; anthers not cordate at base. Whole of New Guinea, but not known from Vogelkop; at 1900-2900 m altitude $\ldots \ldots \ldots \ldots \ldots \ldots \ldots \ldots \ldots \ldots \ldots \ldots \ldots$. U. belensis

b. Receptacle-tube inside hairy (filaments glabrous); anthers deeply cordate at base. - Papua, Baliem Valley; at 2000 m altitude. . . . . . . . 4. U. hippocrepicus

1. Urceodiscus arfakensis W.J. de Wilde \& Duyfjes, spec. nov.

Urceodisco belensi simili fructu longiore $2-3 \mathrm{~cm}$ longo, foliis adaxialiter scabris ob cystolithos grossis differt. - Typus: Sands MJS 6809 (holo K; iso L), Papua, Arfak Mountains.

Climber to $3 \mathrm{~m}$ long; stem 1-1.5 mm diam.; plant sparsely stiff-hairy (hairs less than $0.5 \mathrm{~mm}$ long), green on drying. Leaves: blade entire, ovate-elliptic, $5-9$ by $2-4 \mathrm{~cm}$, base subtruncate or broadly rounded (hardly cordate), apex (long) acute-acuminate, minutely mucronate, margin sparsely inconspicuously dentate (teeth less than $1 \mathrm{~mm}$ long), both surfaces \pm bullate, scabrous by sparse stiff $0.5 \mathrm{~mm}$ long hairs, cystoliths distinct, nerves scabrid-hairy; petiole c. $0.5 \mathrm{~cm}$ long, densely finely stiff-hairy. Male and female flowers not known. Fruit ellipsoid, $2-3$ by $1.5-2 \mathrm{~cm}$, pale brown when dry; fruiting pedicel slender, $6-7.5 \mathrm{~cm}$ long. Seeds numerous, whitish or pale brown, ovoid, $4.5-5.5$ by $3-3.5$ by $2 \mathrm{~mm}$, margin narrow.

Field-note - Fruits green, ripening scarlet.

Distribution - Papua, Vogelkop, Arfak Mountains; known only from the type.

Habitat \& Ecology - Montane forest; climbing near river in shade; at 850 m altitude; fruiting in April.

2. Urceodiscus belensis (Merr. \& L.M. Perry) W.J. de Wilde \& Duyfjes, comb. nov. - Fig. 10, 11

Melothria belensis Merr. \& L.M. Perry (1949) 57. - Type: Brass 11082 (holo A; iso BO, L), Papua.

Melothria cissybium M. Jacobs (1954) 617 (for the male flowering material only). - Type: Womersley 5343 (sphalm. 5543) (holo L; iso LAE), Papua New Guinea.

Herbaceous climber to c. $4 \mathrm{~m}$ long; stem 1(-1.5) mm diam.; plant finely hairy, glabrescent, green on drying. Leaves: blade ovate to elliptic, $3.5-14$ by $2-5.5 \mathrm{~cm}$, entire or towards the base lobed to $1 / 2$ deep (blade then \pm hastate), base subtruncate or broadly shallowly (or deeply) cordate, apex long acute-acuminate, mucronate, margin sparsely finely or coarsely dentate (sometimes shallowly undulate), upper surface with stiff hairs and cystoliths, the nerves more densely hairy, lower surface somewhat hairy or subglabrous; petiole $0.5-2 \mathrm{~cm}$ long, (appressed-)hairy. Male flowers: in a few- to many-flowered condensed or zigzag raceme $0.5-5 \mathrm{~cm}$ long on a $2-5 \mathrm{~cm}$ long peduncle, without or with co-axillary a single male or female flower; pedicel 2-20 mm long, minutely appressed-hairy; perianth $10-15 \mathrm{~mm}$ long, expanded perianth $12-30 \mathrm{~mm}$ diam.; receptacle-tube urceolate-campanulate, sometimes faintly constricted in the middle, $4-7$ by $3-5 \mathrm{~mm}$, glabrous, throat glabrous; sepals $1-2 \mathrm{~mm}$ long, glabrous; petals free or up to $1 / 3$ connate, yellow, (narrowly) elliptic, 6-9 by $4-5 \mathrm{~mm}$, finely hairy on both surfaces, obtuse or rounded; stamens inserted at c. 1/3 from the throat in the receptacle-tube, filaments $4-5 \mathrm{~mm}$ long, straight, glabrous, anthers subcircular or 


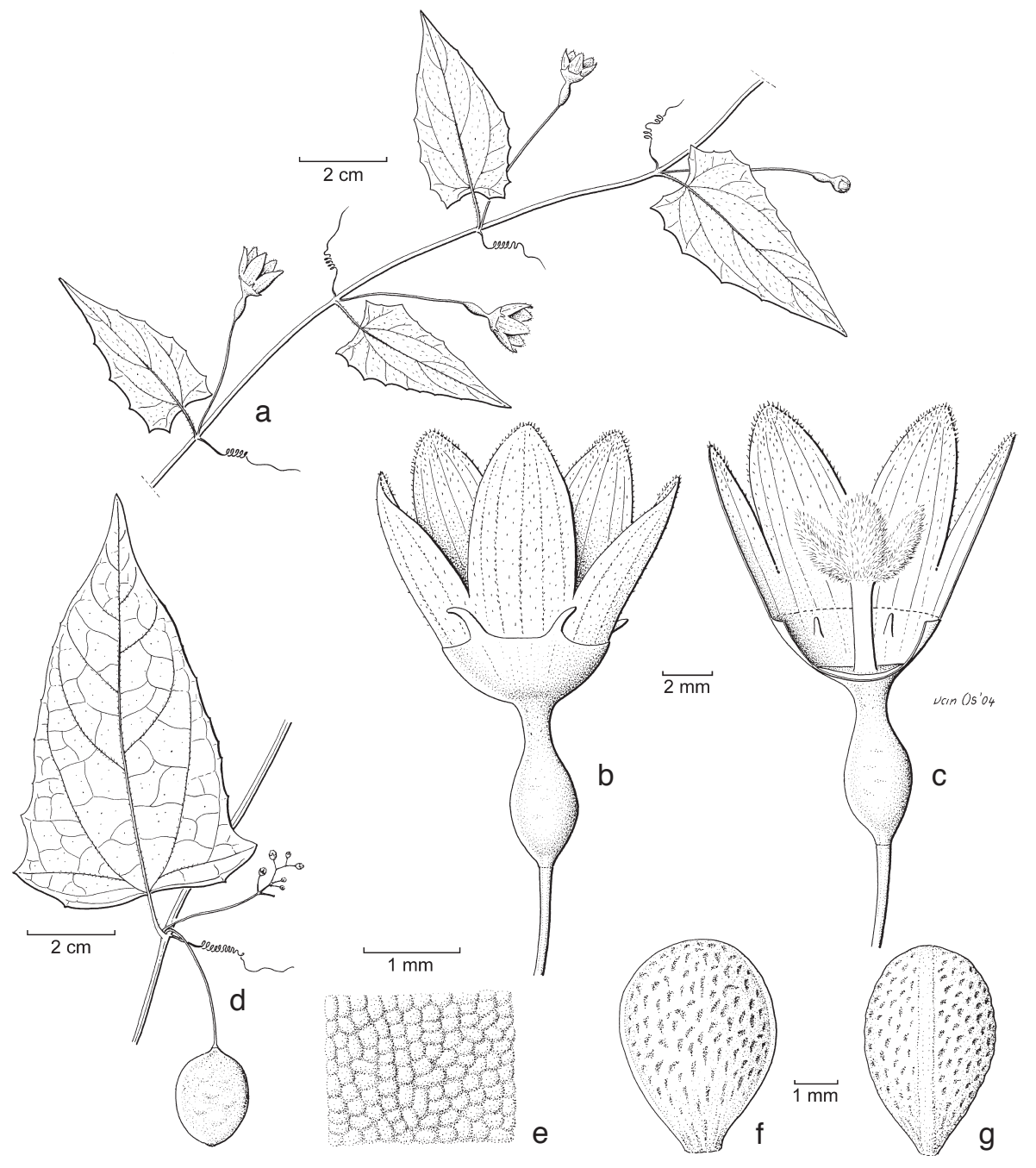

Fig. 10. Urceodiscus belensis (Merr. \& L.M. Perry) W.J. de Wilde \& Duyfjes var. belensis. a. Twig with female flowers; b, c. female flowers; d. node with male inflorescence and one fruit; e. fruit surface, enlarged; f. seed; g. seed showing narrow margin (a-c: Borgmann 210; d-g: Kiprianus, Lawong \& Gideon LAE 69127).

ovate(-elliptic) in outline, c. $1.5 \mathrm{~mm}$ diam., thecae $1 \mathrm{~mm}$ long, divergent, connective broad, at apex truncate or broadly up to $1 \mathrm{~mm}$ produced, obtuse, hairy at both sides; disc 1-2(-3) by $2 \mathrm{~mm}$, entire or sometimes 3-parted by grooves and with 1-3 small nipples c. halfway. Female flowers: solitary or co-axillary with a (later developing) male inflorescence; pedicel 20-40 mm long; ovary ellipsoid, 2-4 mm long, glabrous, with short or long neck 0.5-1.5 mm long; corolla as in male flowers; style c. $4 \mathrm{~mm}$ long, glabrous, stigma c. $4 \mathrm{~mm}$ diam., 3-lobed, the lobes half-patent, \pm narrowly ovoid, c. $3 \mathrm{~mm}$ long, densely papillose; staminodes $1 \mathrm{~mm}$ long, glabrous; disc $0.5 \mathrm{~mm}$ high. 


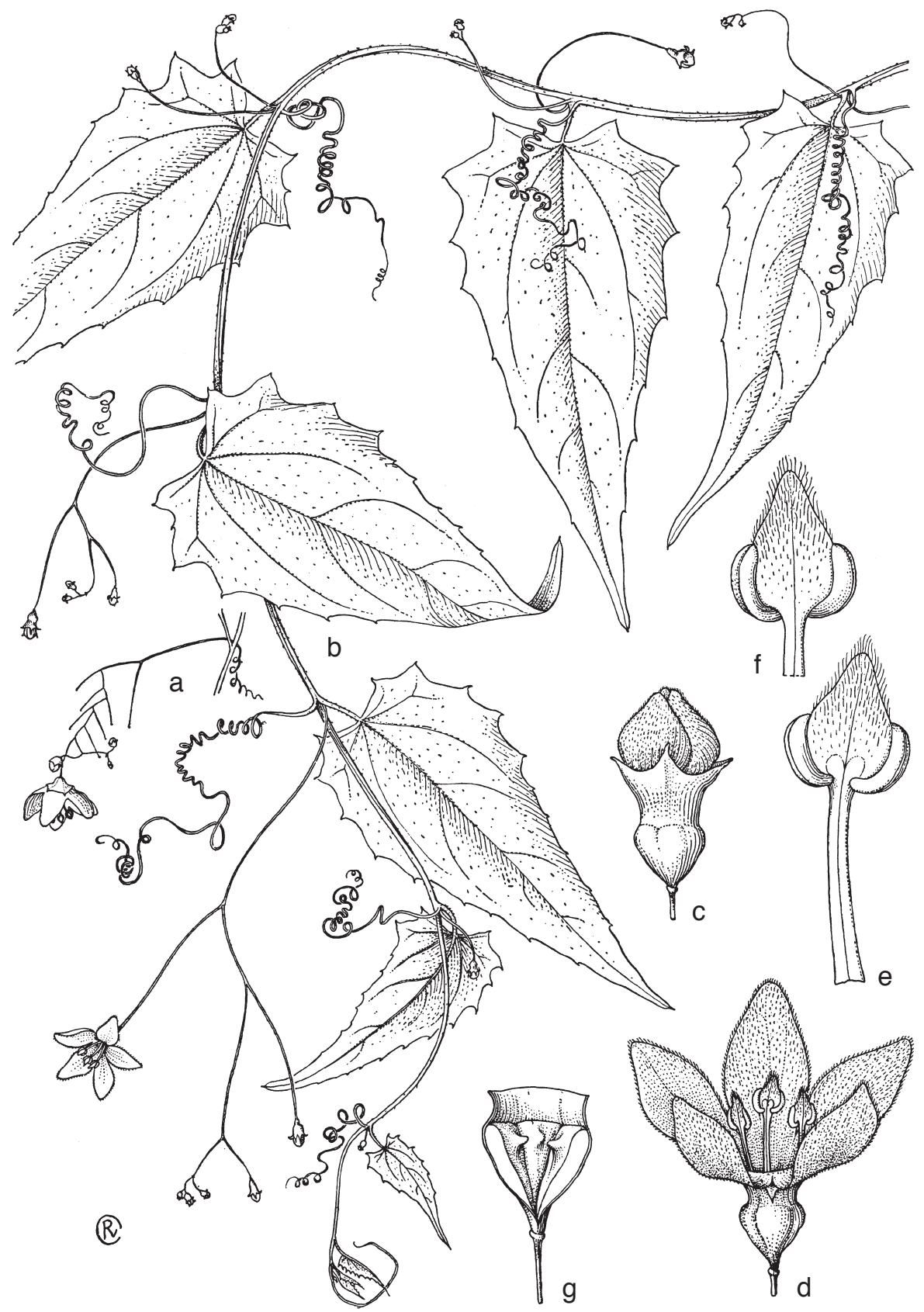

Fig. 11. a: Urceodiscus belensis (Merr. \& L.M. Perry) W.J. de Wilde \& Duyfjes var. belensis. Male inflorescence $(\times 3 / 5)$. - b-g: Urceodiscus belensis (Merr. \& L.M. Perry) W.J. de Wilde \& Duyfjes var. laxa W.J. de Wilde \& Duyfjes. b. Twig with male inflorescences $(\times 3 / 5)$; c, d. male flowers, in bud and open flower, resp. $(\times 2)$; e, f. stamens, ad- and abaxially, resp. $(\times 9)$; g. receptacle-tube, opened (× 5) (a: Womersley 5343, type; b-g: Gyldenstolpe s.n.). 
Fruit short-ellipsoid, 1-2 cm long, pale brown when dry; fruiting pedicel $3-5 \mathrm{~cm}$ long. Seeds numerous, ovoid, $4-5$ by $3.5-4$ by $3 \mathrm{~mm}$, margin narrow.

Field-notes - Petals (orange-)yellow. Anthers orange, pollen yellow. Fruits bright shiny red, edible.

Distribution - In the main range of New Guinea, except Vogelkop.

Habitat \& Ecology - Edges of (Nothofagus) forest, scrub, secondary mixed (oak) forest; climbing in tree fern; at 1900-2900 m altitude; flowering and fruiting mainly April to December.

\section{KEY TO THE VARIETIES}

1a. Male racemes less than $0.5 \mathrm{~cm}$ long, with few subfascicled flowers; pedicels $2-3$ mm long . . . . . . . . . conferta

b. Male racemes 1-4(-5) cm long, flowers more spaced; pedicels 5-20 mm long 2 2a. Male racemes c. 10-flowered; pedicels 5-10(-15) mm long . . . a. var. belensis

b. Male racemes lax, c. 5-flowered; pedicels (5-)10-20 mm long ... . c. var. laxa

a. var. belensis - Fig. 10, $11 \mathrm{a}$; Plate $1 \mathrm{~b}$

Male raceme 1-5 cm long, c. 10-flowered; pedicels 5-10(-15) mm long; receptacletube 4-5 mm long; disc 1-1.5 mm high. Female flowers and fruit as in the species.

Distribution - In the main range of the whole of New Guinea, except Vogelkop.

b. var. conferta W.J. de Wilde \& Duyfjes, var. nov.

A varietate typica racemis masculinis paucifloris, floribus fasciculatis, pedicellis 1-3 mm longis distinctus. - Typus: Hoogland \& Schodde 7537 (holo L; iso CANB), Papua New Guinea.

Male raceme less than $0.5 \mathrm{~cm}$ long, with 1-5 clustered flowers; pedicels 1-3 mm long; receptacle-tube 4-5 mm long; disc 1-1.5 mm high. Female flowers not known. Fruit as in the type-variety.

Distribution - Papua New Guinea, known from 2 collections: Morobe Province (Schodde \& Craven 4943), and Western Highlands Province (Hoogland \& Schodde 7537).

c. var. laxa W.J. de Wilde \& Duyfjes, var. nov. - Fig. 11b-g

Racemus masculinus laxus pauciflorus, pedicelli 10-20 mm longi. - Typus: Hoogland \& Schodde 6798 (holo L; iso CANB), Papua New Guinea.

Male raceme lax, 2-5 cm long, 5-10-flowered; pedicels 10-20 mm long; receptacletube 5-7 mm long; disc 1-3 mm high. Female flowers not known. Fruit as in the type-variety.

Distribution - Papua New Guinea: Western, Eastern and Southern Highlands Provinces and Morobe Province.

Specimens examined:

Bowers 78, 297; Bulmer 103858; Gardner 7270; Gyldenstolpe s.n.; Hoogland \& Schodde 6798; Stevens LAE 51119; Veldkamp \& Stevens 5501. 
3. Urceodiscus carrii W.J. de Wilde \& Duyfjes, spec. nov. - Plate 1c, d

$\mathrm{Ab}$ Urceodisco belensi simili floribus masculis minoribus (petalis c. $3 \mathrm{~mm}$ longis) in racemo spiciformi brevi dispositis, pedicellis 1-3 mm longis distinctus. - Typus: Carr 13647 (holo BM; iso CANB, K, L, SING), E Papua New Guinea.

Small vine; stem $1 \mathrm{~mm}$ diam.; plant sparsely hairy, glabrescent, green on drying. Leaves: blade entire or at base irregularly 3-5-lobed to c. 1/3 deep, narrowly ovate, $7-14$ by $3-8 \mathrm{~cm}$, base shallowly cordate or subtruncate, apex long acute-acuminate, mucronate, margin sparsely short-dentate, upper surface sparsely stiff-hairy, with cystoliths, more densely hairy on nerves, lower surface (sub)glabrous; petiole 1-2 cm long, minutely appressed-hairy. Male flowers: in (5-)10-20-flowered (non-zigzag) spike-like racemes of $0.5-2 \mathrm{~cm}$ long, on a $1-1.5 \mathrm{~cm}$ long peduncle; pedicel $1-3 \mathrm{~mm}$ long, minutely appressed-hairy; perianth c. $5 \mathrm{~mm}$ long, expanded perianth 5-6 mm diam.; receptacle-tube shallowly campanulate, $1-1.5$ by $2(-2.5) \mathrm{mm}$, glabrous, throat glabrous; sepals $0.5 \mathrm{~mm}$ long; petals free, $2.5-3 \mathrm{~mm}$ long, rounded, both surfaces gland-hairy; stamens inserted c. halfway the receptacle-tube, filaments $1.5-2 \mathrm{~mm}$ long, glabrous, straight, anthers subcircular in outline, $1 \mathrm{~mm}$ diam., thecae $0.5 \mathrm{~mm}$ long, situated lateral in the basal part, divergent, connective broad, at apex broadly protruding, sparsely hairy; disc saucer-shaped, 0.5 by $2 \mathrm{~mm}$. Female flowers: (solitary) or co-axillary with male raceme (which develops after the female flower); pedicel 3-5 mm long; ovary ellipsoid, 3-3.5 mm long; corolla as in male flower; style and stigma not investigated (see note). Fruit: solitary, subglobose, $1-1.5 \mathrm{~cm}$ diam., brown-yellow when dry; fruiting pedicel 3-6 cm long. Seeds numerous, ovoid, $4-4.5$ by $2-3$ by $2-2.5 \mathrm{~mm}$, pale brownish yellow, margin narrow.

Field-notes - Flowers cream, off-white or yellowish green. Fruits glossy red.

Distribution - E Papua New Guinea.

Habitat \& Ecology - Short-statue forest, rock faces of escarpment; at 1700$2500 \mathrm{~m}$ altitude; flowering and fruiting: July to December.

Note - The female flowers were not fully studied as Carr 13892 (BM) bears the only female flower known.

Specimens examined:

Carr 13647 (type), 13892; Katik \& Taho LAE 56391; Sayers NGF 19833; Stevens LAE 55707; Takeuchi 12915.

\section{Urceodiscus hippocrepicus W.J. de Wilde \& Duyfjes, spec. nov.}

Urceodisco belensi similis foliis bullatis distinctus; flores masculini incl. tubi receptaculum intus pubescentes; antherae hippocrepicae. - Typus: Kostermans \& Soegeng 655 (holo $\mathrm{L}$; iso A, BO, K), Papua, Baliem Valley.

Small climber to 4 ? $\mathrm{m}$ long; stem 1-1.5 mm diam.; plant sparsely minutely scabroushairy, brown-green on drying. Leaves: blade subentire, (narrowly) ovate, $6-10$ by $2-4.5$ $\mathrm{cm}$, base shallowly or deeply cordate, often \pm hastate, blade gradually narrowed towards the long acute-acuminate apex, margin indistinctly sparsely dentate (teeth less than 0.5 mm long), upper and lower surface \pm bullate, scabrid by sparse minute stiff hairs and inconspicuous cystoliths, nerves more densely minutely appressed-hairy; petiole $0.5-1$ $\mathrm{cm}$ long, minutely appressed-hairy. Male flowers: in a 5- or 6-flowered short \pm zigzag raceme c. $1 \mathrm{~cm}$ long; peduncle $2-3 \mathrm{~cm}$ long, finely appressed-hairy; pedicel c. $10 \mathrm{~mm}$ 
long; perianth c. $10 \mathrm{~mm}$ long, expanded perianth 10-12 mm diam.; receptacle-tube 3-4 by $2-3 \mathrm{~mm}$, sparsely appressed-hairy, throat and inside hairy, hairs $0.5 \mathrm{~mm}$ long; sepals $1 \mathrm{~mm}$ long; petals almost free, (narrowly) elliptic, 5-6 mm long, obtuse, densely hairy at both surfaces; stamens inserted c. halfway in the receptacle-tube, filaments c. $2 \mathrm{~mm}$ long, glabrous, anthers subelliptic in outline, $1.5-2$ by c. $1.5 \mathrm{~mm}$, apex rounded, base deeply cordate, forming an $1 \mathrm{~mm}$ deep sinus, thecae $1.5(-2) \mathrm{mm}$ long, \pm curved and nearly touching at apex, extending downwards on the connective-lobes, connective \pm narrow at apex (where attached to the filament), densely hairy; disc thick-carnose, 1 by $2 \mathrm{~mm}$, faintly 3-lobed. Female flowers and fruit not known.

Field-note - Flowers yellow.

Distribution - Papua, Baliem Valley; known only from the type.

Habitat \& Ecology - On wet places in low, open scrub; at 2000 m altitude.

Note - Because of the deeply cordate anther the two thecae are shaped like a horseshoe.

\section{Urceodiscus parviflora W.J. de Wilde \& Duyfjes, spec. nov.}

Omnibus congeneribus in floribus masculinis minutis, corolla expansa c. $4 \mathrm{~mm}$ diam. differt.

- Typus: Van Royen \& Sleumer 6002 (holo L; iso BO), Papua, Cycloop Mountains.

Low climber; stem $1 \mathrm{~mm}$ diam.; plant sparsely hairy, largely glabrescent, green on drying. Leaves: blade entire, (ovate-)narrowly elliptic, $5-9$ by $2-3 \mathrm{~cm}$, base subtruncate or shallowly broadly cordate, apex acute-acuminate, minutely mucronate, margin (sparsely) repand-dentate, teeth 1-2 mm long, both surfaces sparsely hairy, hairs minute, stiff, cystoliths inconspicuous, nerves more densely hairy; petiole $1-1.5 \mathrm{~cm}$ long, minutely hairy. Male flowers: in a tiny and slender 10-15-flowered spike-like $0.5-1 \mathrm{~cm}$ long raceme on a c. $1 \mathrm{~cm}$ long peduncle, sparsely minutely appressed-hairy; pedicel 1-2 mm long, sparsely minutely appressed-hairy; perianth c. $3 \mathrm{~mm}$ long, expanded perianth (as judged from well-advanced bud) c. $4 \mathrm{~mm}$ diam.; receptacle-tube shallow, $0.5(-1)$ by $2-2.5 \mathrm{~mm}$, throat sparsely minutely hairy; sepals $0.5(-1) \mathrm{mm}$; petals free, $1.5(-2)$ by $1 \mathrm{~mm}$, obtuse, densely minutely hairy outside, glabrous inside; stamens inserted about halfway in the receptacle-tube, filaments (immature) $0.5 \mathrm{~mm}$ long, densely hairy in upper half, anthers ellipsoid, 1 by $0.7 \mathrm{~mm}$, thecae somewhat curved, $1 \mathrm{~mm}$ long, connective narrow, hairy, not produced; disc $0.2-0.5 \mathrm{~mm}$ high, c. $2 \mathrm{~mm}$ wide. Female flowers and fruit not known.

Field-notes - Leaves dark green above, greyish green below. Flowers pale orangeyellow.

Distribution - Papua, Cycloop Mountains, path Ifar to Ormoe, at the camp-site; known only from the type.

Habitat \& Ecology - In secondary regrowth; at $1220 \mathrm{~m}$ altitude; flowering in June.

6. Urceodiscus scabridula (Merr. \& L.M. Perry) W.J. de Wilde \& Duyfjes, comb. nov.

Melothria scabridula Merr. \& L.M. Perry (1949) 56. - Type: Brass 10621 (holo A, not seen; iso BO, L), Papua. 
Small (extensively scrambling) few meters long climber; stem 1-2 mm diam.; plant sparsely hairy, glabrescent, green-brown on drying. Leaves: blade ovate or narrowly ovate in outline, $4-9$ by $3-8 \mathrm{~cm}$, (3- or) 5- (or 7-10-) lobed to $1 / 3$ to nearly to the base (then the segments narrowly elliptic, to $8 \mathrm{~cm}$ long), base shallowly broadly cordate, apex long-acuminate, mucronate, margin sparsely coarsely serrate-dentate, teeth to $5 \mathrm{~mm}$ long, upper surface with sparse stiff hairs especially on the nerves, scabrous, cystoliths present, lower surface (sub) glabrous; petiole 1-2.5 cm long, short-hairy. Male flowers: in 2-5-flowered short (non-zigzag) $0.2-0.5 \mathrm{~cm}$ long racemes on a $1-1.5 \mathrm{~cm}$ long peduncle; pedicel $1-3 \mathrm{~mm}$ long, minutely appressed-hairy; perianth $5-6 \mathrm{~mm}$ long, expanded perianth $5-6 \mathrm{~mm}$ diam.; receptacle-tube $2-2.5$ by $3 \mathrm{~mm}$, glabrous, throat minutely hairy inside; sepals $0.5-1 \mathrm{~mm}$ long, glabrous; petals almost free or to c. 1.5 $\mathrm{mm}$ connate, (narrowly) elliptic, (3-)4-5 by $1.5-2(-3) \mathrm{mm}$, subobtuse or rounded, papillose or (gland-)hairy outside, glabrous or papillose inside; stamens inserted at c. $1 / 3$ from the throat in the receptacle-tube, filaments c. $2 \mathrm{~mm}$ long, densely hairy, hairs $0.3-0.5 \mathrm{~mm}$ long, at apex thickened and c. $90^{\circ}$ curved inwards, anthers ellipsoid, c. 1.3 by $1 \mathrm{~mm}$, thecae vertical, straight, $1 \mathrm{~mm}$ long, connective narrow with few sparse minute hairs; disc a thick-carnose cupule, $0.5(-1)$ by $2(-3) \mathrm{mm}$, margin smooth or \pm wavy. Female flowers: solitary or co-axillary with male inflorescence; pedicel 20-30 $\mathrm{mm}$ long; ovary subglobose-ellipsoid, c. 1.5 by $1 \mathrm{~mm}$, neck $0.5 \mathrm{~mm}$ long, perianth as in male flower; receptacle-tube c. 2 by $4 \mathrm{~mm}$; style c. $2 \mathrm{~mm}$ long, at apex 3 -armed, each arm c. $1.5 \mathrm{~mm}$ long, with elongated stigma-lobe c. $1.5 \mathrm{~mm}$ long, out-curved, densely hairy; staminodes subulate, c. $1.5 \mathrm{~mm}$ long, hairy. Fruit subglobose, $0.5-1 \mathrm{~cm}$ diam., \pm smooth or minutely pustulate, blackish brown when dry (red when fresh); fruiting pedicel $2.5-5 \mathrm{~cm}$ long. Seeds $10-20$, ovoid, $4-4.5$ by c. 3 by c. $2.5 \mathrm{~mm}$, pale brown, margin faint.

Field-notes - Flowers yellow. Fruits red.

Distribution - SW Papua: near Lake Habbema; Valentijn Mountains; P.T. Freeport Indonesia Concession Area.

Habitat \& Ecology - Mossy forest, on tree stump; undergrowth in disturbed montane forest; forest clearings; at 2200-2800 m altitude; flowering and fruiting: August to December.

Note - This species is remarkable by its filaments which are thickened at apex and abruptly in-curved for c. $90^{\circ}$.

Specimens examined:

Brass 10621 (type), 11046; Johns 9208; Mangen 2395; Sands 7143.

7. Urceodiscus viridis W.J. de Wilde \& Duyfjes, spec. nov. - Fig. 12; Plate 1a

Urceodisco belensi pedicellis masculinis brevibus 1-2 mm longis, floribus masculinibus brevioribus longitudinibus $10 \mathrm{~mm}$ brevioribus, petalis $4-5 \mathrm{~mm}$ longis distinctus; antherae ellipticae connectivo angusto. - Typus: W. \& M. Vink BW 15396 (holo L; iso CANB, $\mathrm{K})$.

Small vine; stem 1(-1.5) mm diam.; plant sparsely minutely hairy, glabrescent, green on drying. Leaves: blade ovate or narrowly ovate, $4-8$ by $(1.5-) 2-5 \mathrm{~cm}$, entire or at base with an odd lobe to $1 / 3$ deep, base broadly rounded, subtruncate or shallowly cordate, apex acute(-acuminate), minutely mucronate, margin sparsely short serrate-dentate, 

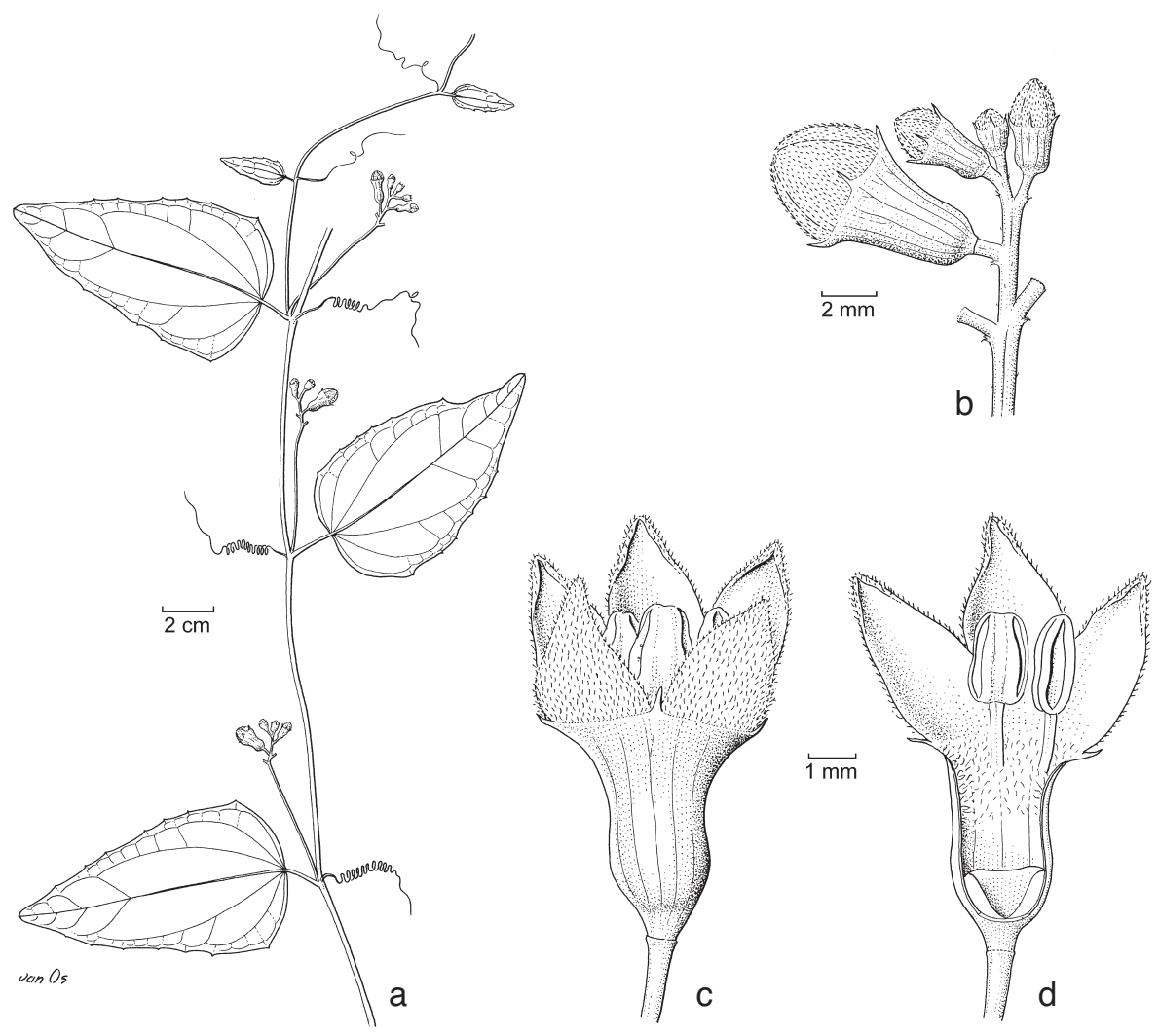

Fig. 12. Urceodiscus viridis W.J. de Wilde \& Duyfjes. a. Twig with male inflorescences; b. detail of male inflorescence, showing four buds; c, d. male flowers (all: W. \& M. Vink BW 15396, type).

teeth 1-2(-3) mm long, upper surface glabrous except for minute soft hairs on nerves, cystoliths sparse, inconspicuous, lower surface glabrous; petiole $0.5-1 \mathrm{~cm}$ long, partly appressed-hairy. Male flowers: $3-7$ in a short (non-zigzag) spike-like $0.5-1 \mathrm{~cm}$ long raceme on a $2-3 \mathrm{~cm}$ long peduncle; pedicel 1-2 mm long, glabrous; perianth 7-10 $\mathrm{mm}$ long, expanded perianth c. $10 \mathrm{~mm}$ diam.; receptacle-tube c. 5 by $2.5 \mathrm{~mm}$, subglabrous, throat and upper half of tube minutely hairy inside; sepals c. $0.5 \mathrm{~mm}$ long; petals free, 4-5 by $2.5 \mathrm{~mm}$, subobtuse, minutely hairy outside, glabrous inside; stamens inserted at c. 1/4 from the apex in the receptacle-tube, filaments c. $2 \mathrm{~mm}$ long, straight, glabrous, anthers \pm connivent, ellipsoid, c. 2 by $1 \mathrm{~mm}$, thecae straight, c. $2 \mathrm{~mm}$ long, connective narrow, not produced; disc c. 1.5 by $2 \mathrm{~mm}$. Female flowers and fruit not known.

Field-notes - Rather common climber. Calyx green; corolla, connective and filaments light green; anthers yellow; flowers in March.

Distribution - Papua, Vogelkop, Tanah Merah, W side of Lake Ajamaru, $1^{\circ} 8^{\prime} \mathrm{S}$, $132^{\circ} 13^{\prime} \mathrm{E}$, known only from the type.

Habitat \& Ecology - Young secondary forest on strongly humified limestone silt; at $220 \mathrm{~m}$ altitude. 


\section{ZEHNERIA - Fig. 1a, 2f; Table 1}

Zehneria Endl. (1833) 69. - Type: Zehneria baueriana Endl.

Small climbers, annual or subperennial; usually dioecious; usually blackish on drying. Probract linear, minute, caduceus. Tendrils simple. Leaves simple. Flowers small, white or creamy; sepals minute, (narrowly) triangular or narrowly elliptic, usually subpatent; petals free, (narrowly) elliptic, valvate or imbricate in bud; receptacle-tube campanulate. Male inflorescence: a short- or long-peduncled few- or many-flowered condensed raceme, when monoecious co-axillary with female flower(s) or not. Bracts absent. Male flowers: pedicel short, 2-10(-15) mm long, persistent; stamens 3, inserted in the lower half of the receptacle-tube, usually near the base, filaments longer than the anther, anthers all 2-thecous, \pm included or just exserted, thecae lateral, straight or curved, not divergent, connective narrow or broad and \pm thickened adaxially, not or little produced at apex; disc (depressed-) globose or frequently 3-lobed. Female flowers: solitary or few at the node, or few in a peduncled cluster, when monoecious co-axillary with a male raceme, or mixed with male flowers in a peduncled raceme; pedicel short (or long); ovary globose with slender neck, or ellipsoid; stigma 3-lobed, or 3 on short style-arms, papillose or hairy; staminodes present; disc free, annular. Fruit 1 or several, usually with short fruiting pedicel, globose or ellipsoid, $0.5-3 \mathrm{~cm}$ long, not or hardly beaked, glabrous, green, ultimately red, or purplish blackish, pulpy; pericarp cartilaginous, minutely pitted or tessellate. Seeds several or numerous, compressed, ovate or elliptic, whitish, not sculptured, margin narrow but distinct (indistinct in Z. immarginata), usually with square edge, base without wing.

A genus of c. 25 species distributed in the tropics of the Old World: Africa and Madagascar and in SE Asia, from India, China, through Malesia, to N Australia and far into the Pacific; c. 18 species in Asia, Malesia and the Pacific, 1 species in Australia.

Note - Several species are weakly defined. They are in the present enumeration sometimes only distinguishable on the colour of the ripe fruits. Further study is needed.

\section{KEY TO ASIAN AND PACIFIC SPECIES OF ZEHNERIA}

1a. Leaf blade (narrowly) trullate, base \pm rounded or broadly connate. [Female flowers

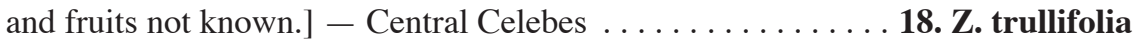

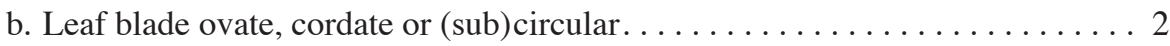

2a. Ovary and fruit globose, fruit c. $1 \mathrm{~cm}$ diam. or less, seeds margined . . . . . . 3

b. Ovary and fruit subglobose or ellipsoid, fruit $1 \mathrm{~cm}$ long or longer (if smaller, then seeds without margin $\ldots \ldots \ldots \ldots \ldots \ldots \ldots \ldots \ldots \ldots \ldots \ldots \ldots \ldots \ldots \ldots$

3a. Female flower and fruit solitary, with long pedicel; fruiting pedicel $1.5-3 \mathrm{~cm}$

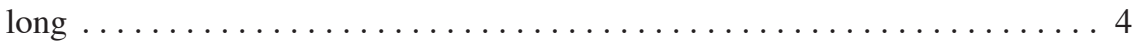

b. Female flower(s) and fruit solitary, fascicled, or clustered in a peduncled raceme;

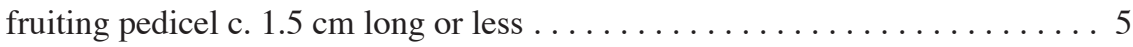

4a. Male flowers in an elongated, spike-like raceme (co-axillary with a female flower), with flowers dispersed along the rachis. - N India, Thailand, Myanmar . . . . . . . 

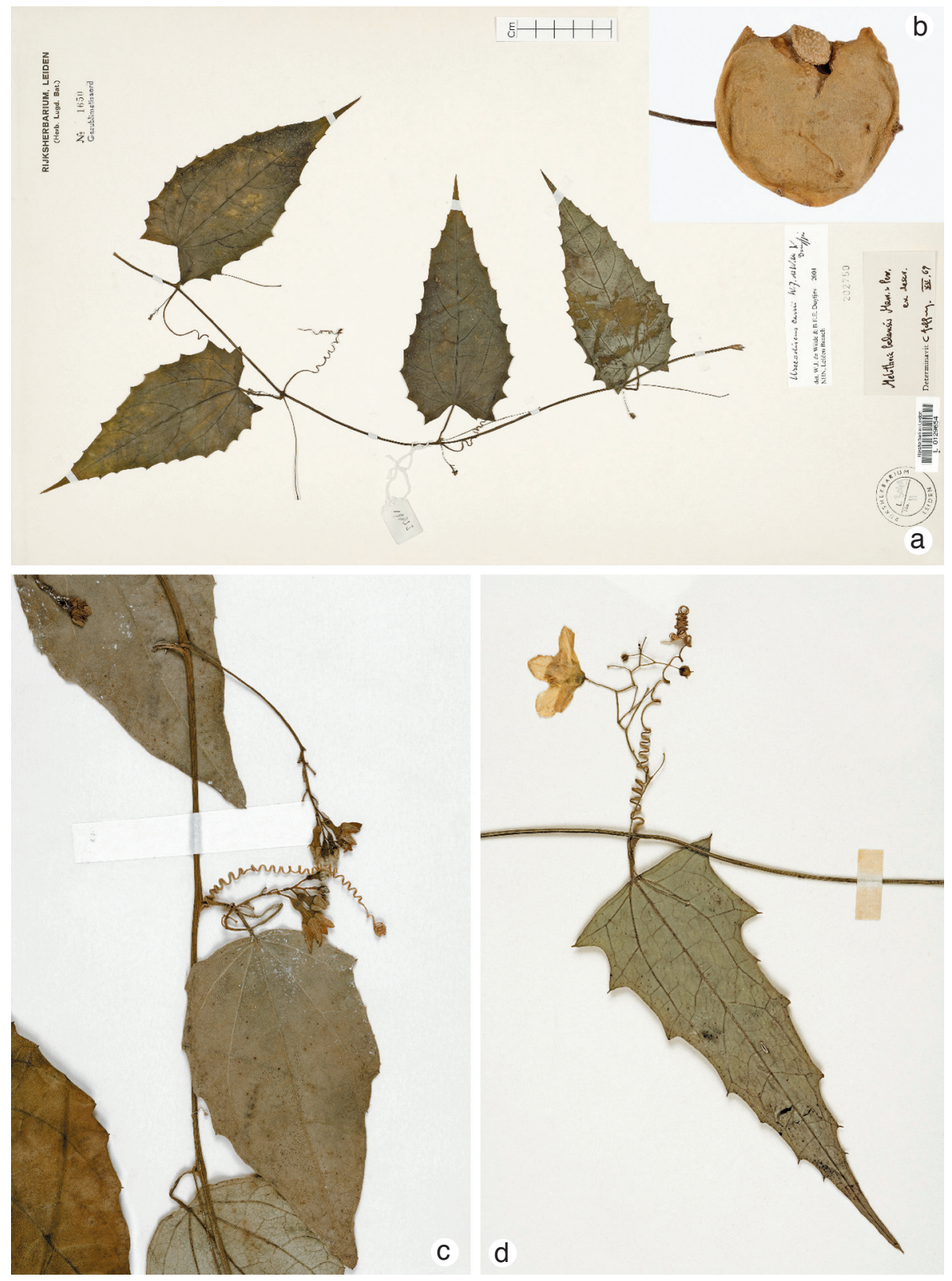

Plate 1. a. Urceodiscus viridis W.J. de Wilde \& Duyfjes; b. Urceodiscus belensis (Merr. \& L.M. Perry) W.J. de Wilde \& Duyfjes var. belensis, fruit; c, d. Urceodiscus carrii W.J. de Wilde \& Duyfjes (a: W. \& M. Vink BW 15396, type; b: Womersley 5343, type; c: Sayers NGF 19833; d: Takeuchi 12915). Photos Ben Kieft. 
b. Male flowers (co-axillary with a female flower) in a pedunculate condensed cluster.

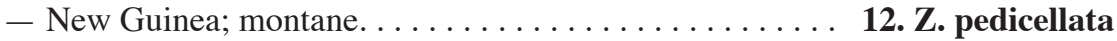

5a. Monoecious with female flowers (and fruits) and male flowers often in one single raceme-like inflorescence. - New Guinea; montane ...... 14. Z. pisifera

b. Mostly dioecious, flowers (male) condensed in a (pedunculate) cluster . . . 6

6a. Fruit mostly several on a long common peduncle [if solitary, then usually co-axil-

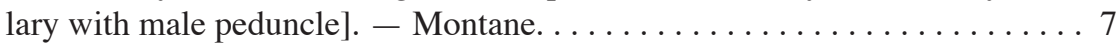

b. Fruit single or few, in a sessile or short-pedunculate cluster. - Lower montane

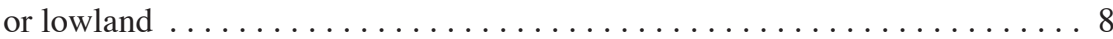

7a. Fruit ultimately red(?). - S India . . . . . . . . . . . . hookeriana

b. Fruit ultimately purple-black. - Malesia, Taiwan . . . . . . 15. Z. repanda

8a. Fruit 1 (rarely 2 or 3 ) per node, c. $1 \mathrm{~cm}$ diam., pedicelled, but without peduncle, red when ripe. - Widespread in S India, Sri Lanka and SE Continental Asia; rare in Malesia (N Sumatra, Peninsular Malaysia and Sabah); lowland and montane

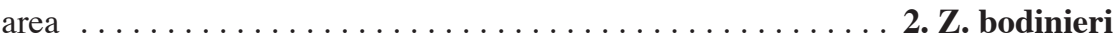

b. Fruit 1 or $2-5$ per node, $0.6-0.8 \mathrm{~cm}$ diam., fruits on a common peduncle to $1 \mathrm{~cm}$ long, greenish when ripe. - Java, Salayar Island, Lesser Sunda Islands; lower

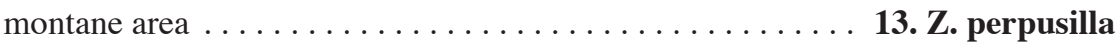

9a. Fruiting pedicel in solitary fruit about as long as or (much) longer than the fruit, c. $1.5 \mathrm{~cm}$ long or more (or fruit few fascicled on a peduncle). Stamens inserted somewhat above the base or at about halfway in the receptacle-tube, thecae straight with connective \pm narrow or thecae curved with connective broad in the middle.

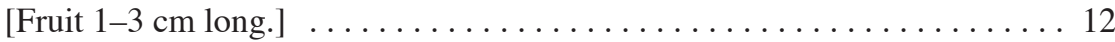

b. Fruiting pedicel shorter than the fruit, c. $1 \mathrm{~cm}$ long or less. Stamens inserted at the base of the receptacle-tube, thecae straight, with connective \pm narrow. . 10

10a. Fruit 1.5-2.5 cm long; pericarp not pitted. Seeds hairy. Male inflorescence subsessile. - New Caledonia . . . . . . . . . . . . . . 11. Z. neocaledonica

b. Fruit 1-1.5 cm long; pericarp finely pitted. Seeds glabrous. Male inflorescence

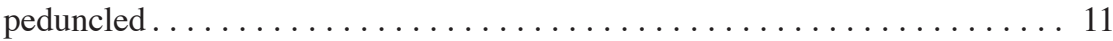

11a. Usually monoecious (see note under Z. maysorensis). $-\mathrm{S}$ India . . . . . . . $\ldots \ldots \ldots \ldots \ldots \ldots \ldots \ldots \ldots \ldots \ldots \ldots \ldots \ldots \ldots \ldots \ldots \ldots$. $\mathbf{Z}$ maysorensis

b. Mostly dioecious. - Malesia, east to New Guinea, Queensland(?), Christmas

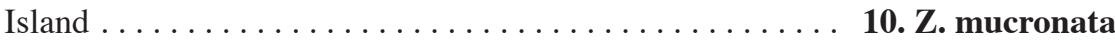

12a. Ripe fruit purple-black. - Taiwan, Ryukyu Islands, Guam . . 6. Z. guamensis

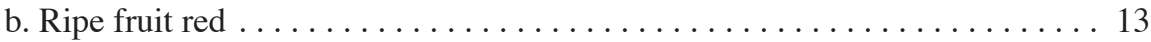

13a. Male inflorescence proliferating into a long-peduncled slender, loose raceme; flowers almost glabrous inside. - Tonga, Tahiti ....... 16. Z. tahitensis

b. Male inflorescence subsessile or peduncled, the flowers fascicled, in a condensed raceme, or in a loose raceme; flowers hairy inside $\ldots \ldots \ldots \ldots \ldots \ldots 14$

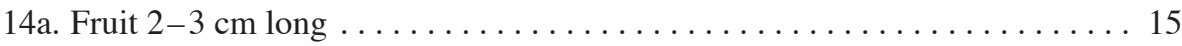

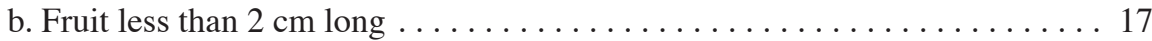

15a. Fruit fascicled, subsessile. Thecae curved, \pm horizontal. Disc consisting of 3 separate parts. Style at apex 3-armed, each arm with a \pm 2 -lobed stigma. - New Caledonia, Norfolk Islands . . . . . . . . . . . . Z. baueriana

b. Fruit solitary, long-pedicelled or few-fascicled on a common peduncle . . . 16 
16a. Fruit solitary (or with 2). Seeds c. 4 mm long. [Male inflorescences not known.] — Lesser Sunda Islands: Lombok . . . . . . . . . . . . . . . 3. Z. elbertii

b. Fruit solitary or few-fascicled on a common peduncle. Seeds 5-6 mm long. Thecae \pm straight, vertical. Disc simple, more or less 3-lobed. Style at apex not armed, with deeply 3-lobed stigma. - Widespread: Bismarck Archipelago, Solomon Islands, New Hebrides, Fiji, Samoa. . . . . . . . . . . . 5. Z. grayana

17a. Fruit (1.3-)1.5-2 cm long. Seeds 4-5 mm long, narrowly margined. - New Guinea; lowland up to $1000(-1750) \mathrm{m}$ altitude ...... 4. Z. erythrobacca

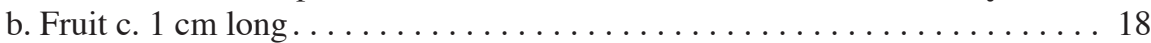

18a. Plant drying brown. Seeds c. $3 \mathrm{~mm}$ long, edge rounded, unmargined. - Lesser Sunda Islands: Lombok, Flores; at 1500-3000 m altitude . . 8. Z. immarginata

b. Plant drying green. Seeds $5 \mathrm{~mm}$ long, with conspicuous broad square edge, not obviously margined. - E Papua New Guinea; at $200 \mathrm{~m}$ altitude . . . . . . . . . . .

19. Z. viridifolia

\section{Zehneria baueriana Endl.}

Zehneria baueriana Endl. (1833) 69. - Pilogyne baueriana (Endl.) Steud. (1841) 334 (erroneously cited in Cogniaux $(1881,1916)$ as Pilogyne zehneria Steud. (1841) 334). - Melothria baueriana F. Muell. (1868) 188; Cogn. (1881) 610; (1916) 109. - Lectotype (here chosen): F. Bauer in Herb. Endlicher s.n., male (W; iso B $\dagger, \mathrm{K}, \mathrm{LE})$, Norfolk Islands.

Distribution - Norfolk Islands and New Caledonia.

Notes -1 . Zehneria baueriana is here regarded as a species restricted to Norfolk Islands (type) and New Caledonia; it is not further distributed in the Pacific as generally assumed by various authors, e.g. by Smith (1981) under the name Z. mucronata. The resembling Z. grayana is widespread in the Pacific. Zehneria baueriana has not been much collected, but it is well known by the detailed drawings of the typematerial, published by Endlicher (1841), f. 116 and 117 for the male and female flower, respectively. It is, like Z. grayana, a comparatively stout vine, distinct by fascicled subsessile fruits, male flowers with a disc consisting of 3 contiguous half-globose parts, stamens inserted about halfway the receptacle-tube, and anthers with curved, more or less horizontal thecae, with broad connective, bulging in the middle; female flowers with a shortly 3-armed style, each arm with a 2-lobed stigma, and disc consisting of 3 separate elongated parts.

2. Zehneria baueriana, the type-species of the genus Zehneria, is rather isolated within the genus by the above-mentioned combination of characters, which may occur individually in other species in New Guinea or in the Pacific area.

Specimens examined:

Baumann-Bodenheim 8604, 10315.

2. Zehneria bodinieri (H. Lév.) W.J. de Wilde \& Duyfjes - Plate 7c, 8a, b

Zehneria bodinieri (H. Lév.) W.J. de Wilde \& Duyfjes (2004) 17. - Melothria bodinieri H. Lév. (1914) 122. - Lectotype (De Wilde \& Duyfjes, 2004): Bodinier 1957 (E; iso P), China, KouyYang.

Melothria perpusilla (Blume) Cogn. var. subtruncata Cogn. (1881) 608. - Lectotype (De Wilde \& Duyfjes, 2004): Thwaites CP 1613 (K; iso L), Sri Lanka. 

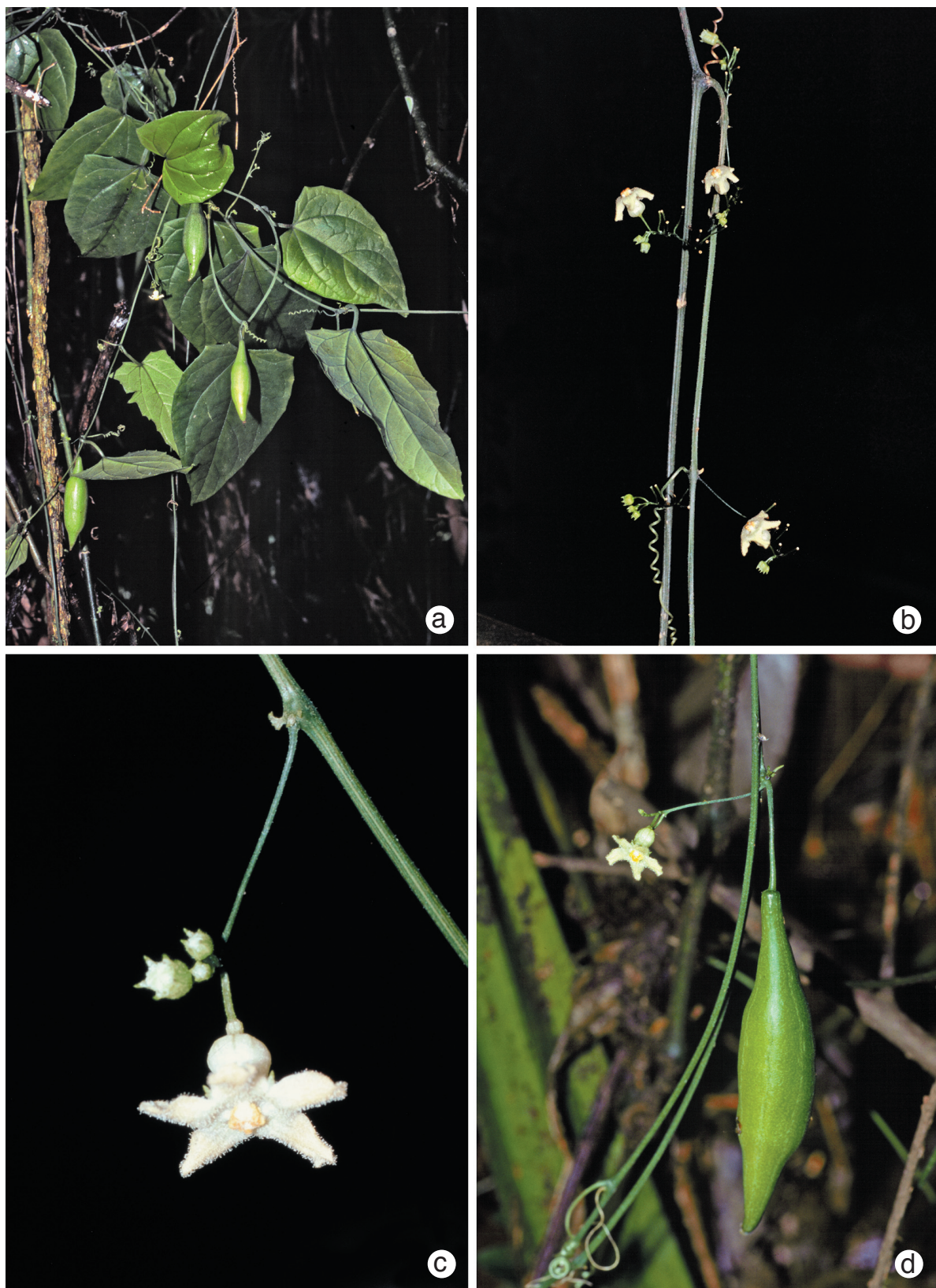

Plate 2. Indomelothria chlorocarpa W.J. de Wilde \& Duyfjes subsp. halimunensis W.J. de Wilde \& Duyfjes (a: Wiriadinata 8145; b: De Wilde 21927; c, d: De Wilde 22271). Photos a: Harry Wiriadinata; $b-d$ : De Wilde. 

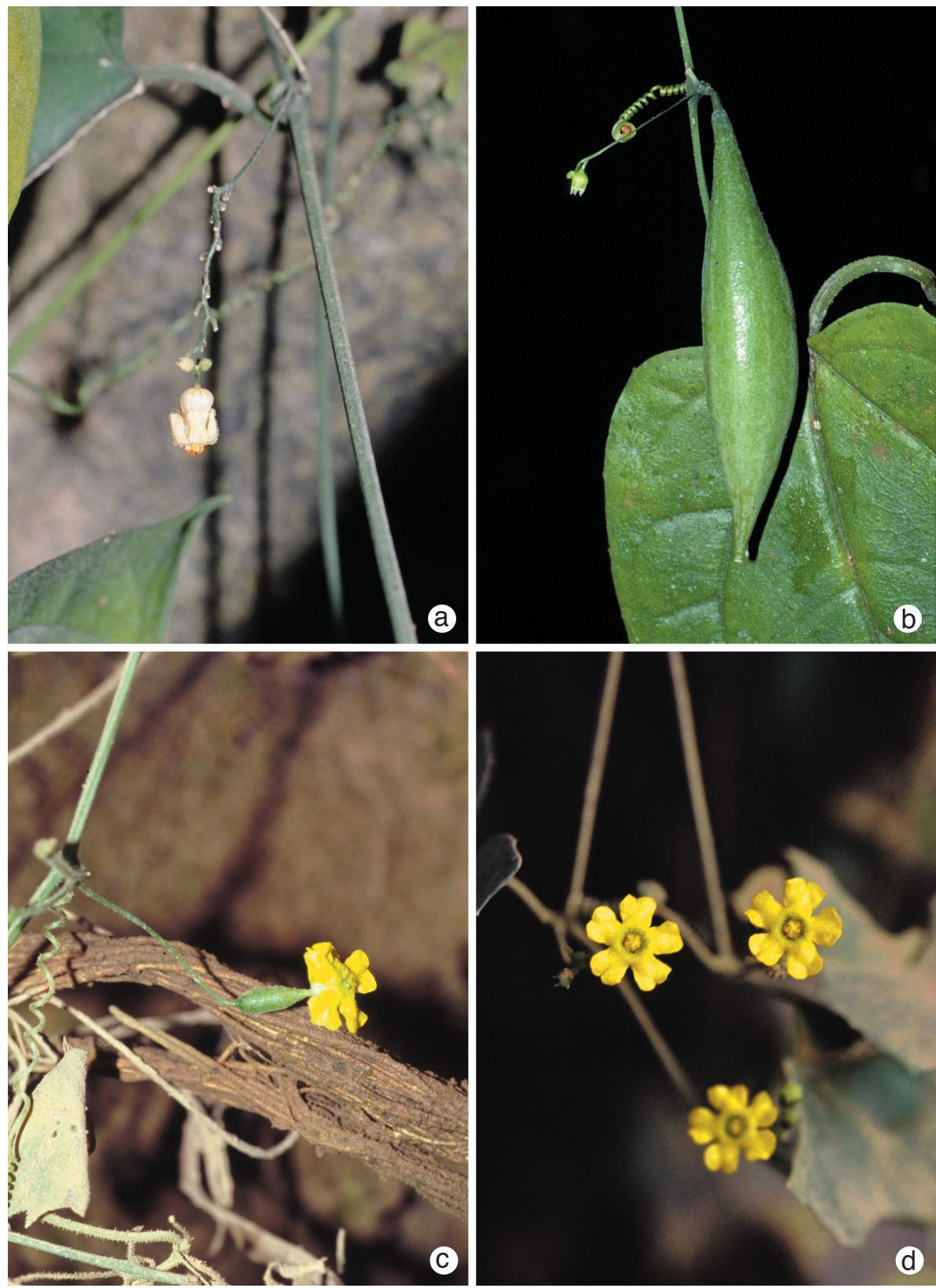

Plate 3. a, b. Indomelothria chlorocarpa W.J. de Wilde \& Duyfjes subsp. chlorocarpa; c, d. Melothria pendula L. (a, b: SAN 143915; c: SAN 141901; d: SAN 139454). Photos De Wilde. 
Zehneria hookeriana auct. non (Wight \& Arn.) Arn.: C.B. Clarke (1879) 624, p.p.

Melothria perpusilla auct. non (Blume) Cogn.: Cogn. (1881) 607, p.p.; (1916) 106, p.p.; Gagnep. (1921) 1061; Craib (1931) 764 (incl. var. subtruncata); Chakrav. (1959) 146, p.p.

Zehneria maysorensis auct. non (Wight \& Arn.) Arn.: Gandhi (1976) 181; K.M. Matthew (1983) 655, p.p.; Keraudren (1975b) 51, pl. 9: 1-4; A.M. Lu \& Zhi Y. Zhang (1986) 173, pl. 45: 9-11; S.K. Chen (1995) 317, pl. 82: 1-5; P.H. Hô (1991) 716, f. 1986; Philcox (1997) 41, p.p.

Bryonia oxyphylla Wallich Cat. 6697, nom. nud.

Bryonia cissoides Wallich Cat. 6698, nom. nud.

Subherbaceous 2-6 m long climber; monoecious; plant subglabrous, generally drying (dark) brownish. Leaves: blade ovate-triangular, $4-12$ by $3-10 \mathrm{~cm}$, rarely shallowly lobed, base subtruncate or broadly shallowly cordate, apex acute-acuminate, margin denticulate; petiole $2-5 \mathrm{~cm}$ long. Inflorescences: in male a peduncled 3-10-flowered short or sometimes \pm spike-like proliferous raceme, peduncle $1-5 \mathrm{~cm}$ long, usually co-axillary with a previously developed single female flower; female flowers solitary or rarely few, subumbellate, peduncled. Male flowers: pedicel 1-4 mm long; receptacle-tube c. 3 by $2 \mathrm{~mm}$, inside with long hairs, especially at the throat; sepals 0.5 mm long; petals ovate, c. $2 \mathrm{~mm}$ long, subacute, inner surface and apex hairy; stamens inserted halfway the receptacle-tube or rather lower (but not at the base of the tube), filaments 1-2 mm long, subglabrous or long-haired about the middle, anthers circular in outline, $1 \mathrm{~mm}$ diam., thecae curved, the two forming nearly a ring, connective \pm hairy, not produced; disc depressed globose, $1 \mathrm{~mm}$ diameter. Female flowers: pedicel slender, 2-5 mm long; ovary ovoid-globose, c. 3 by $2.5 \mathrm{~mm}$, glabrous (except minute raised gland-dots), neck $1 \mathrm{~mm}$ long; perianth as in male flower but petals $2.5-3 \mathrm{~mm}$ long; style c. $3 \mathrm{~mm}$ long, glabrous, stigma 3-lobed, 1.5-2 mm diam., papillose; disc $0.5 \mathrm{~mm}$ high; staminodes slender, c. $2 \mathrm{~mm}$ long, the basal portion adnate with the receptacle-tube. Fruit solitary (rarely 2 or 3), globose, $0.8-1.2 \mathrm{~mm}$ diam., glabrous, green, at last red, finely netted or pitted when dry; fruiting pedicel $0.3-1 \mathrm{~cm}$ long. Seeds rather many, (narrowly) elliptic, c. 5 by $3-3.5 \mathrm{~mm}$, narrowly margined, smooth, pale brownish when dry.

Distribution - Widespread; in Sri Lanka and S India, and from northern India to China (including Taiwan), Indo-China, Thailand, south-east to Sumatra, Peninsular Malaysia, Sabah, and Palawan.

Habitat \& Ecology - Disturbed places, forest edges, and scrub; at 500-1700 m altitude; flowering and fruiting throughout the year.

\section{Zehneria elbertii W.J. de Wilde \& Duyfjes, spec. nov.}

A Zehneria grayana seminibus c. $4 \mathrm{~mm}$ longis vix marginatis differt. - Typus: Elbert 1637 (holo L; iso FR, not seen), Lesser Sunda Islands (Lombok).

Stoutish climber to c. 5(?) $\mathrm{m}$ long; dioecious; stem (1-) $2 \mathrm{~mm}$ diam.; plant greenish brown on drying. Probract linear, c. $5 \mathrm{~mm}$ long. Leaves: blade entire, broadly ovate, $6-10$ by $6.5-8.5 \mathrm{~cm}$, base broadly shallowly cordate, margin sparsely short-dentate, both surfaces glabrous, but faintly scabrous above by minute cystoliths; petiole 3-6.5 $\mathrm{cm}$ long, glabrous. Male inflorescences and male flowers not known. Female flowers: 1 (or 2) solitary at the node; pedicel c. $10 \mathrm{~mm}$ long; ovary ellipsoid to narrowly ellipsoid, c. 7 by $1.5 \mathrm{~mm}$, glabrous, neck $1 \mathrm{~mm}$ long; receptacle-tube campanulate, c. 2.5 by $3 \mathrm{~mm}$, throat densely woolly hairy, hairs $0.5-1 \mathrm{~mm}$ long; sepals $0.5(-1) \mathrm{mm}$; petals 
c. $3 \mathrm{~mm}$ long, outside glabrous, inside sparsely gland-hairy; style c. $2.5 \mathrm{~mm}$ long, at apex with 3 style-arms $0.3 \mathrm{~mm}$ long, stigma-lobes down-curved, (narrowly) ovoid, thick, papillose, c. $1.5 \mathrm{~mm}$ long; staminodes c. $2 \mathrm{~mm}$ long, inserted towards the base of the receptacle-tube, densely long woolly hairy near the apex; disc large, $0.5(-1)$ by c. $2 \mathrm{~mm}$, margin somewhat irregularly sinuate. Fruit solitary (or 2); narrowly ellipsoid, $(2.5-) 3$ by c. $1 \mathrm{~cm}$, apex apiculate, red(?); pericarp cartilaginous, smooth (not pitted), light brown; fruiting pedicel $1-1.5 \mathrm{~cm}$ long. Seeds numerous, nearly flat, ovate, c. 4 $\mathrm{mm}$ long, palish, smooth, unmargined.

Distribution - Known only from the type from Lombok: north-eastern flank of Mt Rinjani, Sembalun Highlands.

Habitat \& Ecology - In scrub-forest; on loamy soil over volcanic breccia; at 1100-1300 m altitude; flowering and fruiting: May.

Notes -1 . This species, known only from one female flowering and fruiting collection, is of a stout habit and obviously belongs, on account of the basal insertion of the staminodes in the female flower, to Zehneria. However, it also has traits of Neoachmandra, e.g. the solitary rather long-pedicelled fruits, the smooth (not pitted) pericarp, and the unmargined seeds.

2. Zehneria elbertii keys out beside the widespread Z. grayana from the Pacific. The sole specimen of $Z$. elbertii differs in various minor, difficult to define, characteristics, but we feel that additional material will prove its status as a distinct species.

\section{Zehneria erythrobacca W.J. de Wilde \& Duyfjes, spec. nov. - Fig. 13a-h}

A Zehneria mucronata in plantis monoecis differt; pedelli masculini 5-10 mm longi; receptaculi tubus intus dense lanatus; fructus $1-3(-5)$ laxe fasciculati ellipsoidei c. 1.5 cm longi rubri; pedicellus in fructu 1-2.5 cm longus. - Typus: Brass 21720 (holo L; iso A), Papua New Guinea.

Melothria indica auct. non Lour.: P.G. Peekel (1984) 543, f. 867.

Diplocyclos palmatus auct. non (L.) C. Jeffrey: P.G. Peekel (1984) 547, f. 873, p.p.

Climber or creeper, 1.5-5 m long; monoecious; stem 1(-3) mm diam.; plant sparsely minutely hairy, glabrescent, brown on drying. Probract minute. Leaves: blade entire, ovate, $3-9(-11)$ by $2.5-9(-14) \mathrm{cm}$, sometimes \pm hastate or lobed to $1 / 5 \mathrm{deep}$, base (narrowly or) broadly cordate, apex short or long acuminate, margin (sparsely) coarsely dentate, upper surface subglabrous or scabrous, with minute cystoliths, lower surface glabrous but nerves sometimes \pm hairy; petiole $1-5.5 \mathrm{~cm}$ long, glabrous or scabrous. Male inflorescences: subsessile or peduncled racemes, peduncle up to $3 \mathrm{~cm}$ long, racemes $0.1-0.5 \mathrm{~cm}$ long (rarely up to $2 \mathrm{~cm}$ long), 5-15-flowered, flowers dense or loose, with rather long pedicels, sometimes mixed with female flowers. Male flowers: pedicels 5-10 $\mathrm{mm}$ long; expanded perianth 4-6(-8) mm diam.; receptacle-tube $1.5-2.5$ by $2-3 \mathrm{~mm}$, outside glabrous, inside (especially at the throat) densely white woolly hairy, hairs to $1 \mathrm{~mm}$ long; sepals $0.5-1.5 \mathrm{~mm}$ long; petals $2-3(-4) \mathrm{mm}$ long, minutely gland-hairy outside; stamens inserted towards the base of the receptacle-tube, filaments 1.5-2 mm long, woolly hairy in upper half, anthers partly exserted, ellipsoid, 1(-1.5) mm long, thecae \pm straight, connective narrow; disc depressed globose or at apex \pm concave, $0.5(-1)$ by $1-1.5 \mathrm{~mm}$, not or faintly lobed. Female flowers: few or several in a subsessile short raceme, or one female flower below male flowers in a 

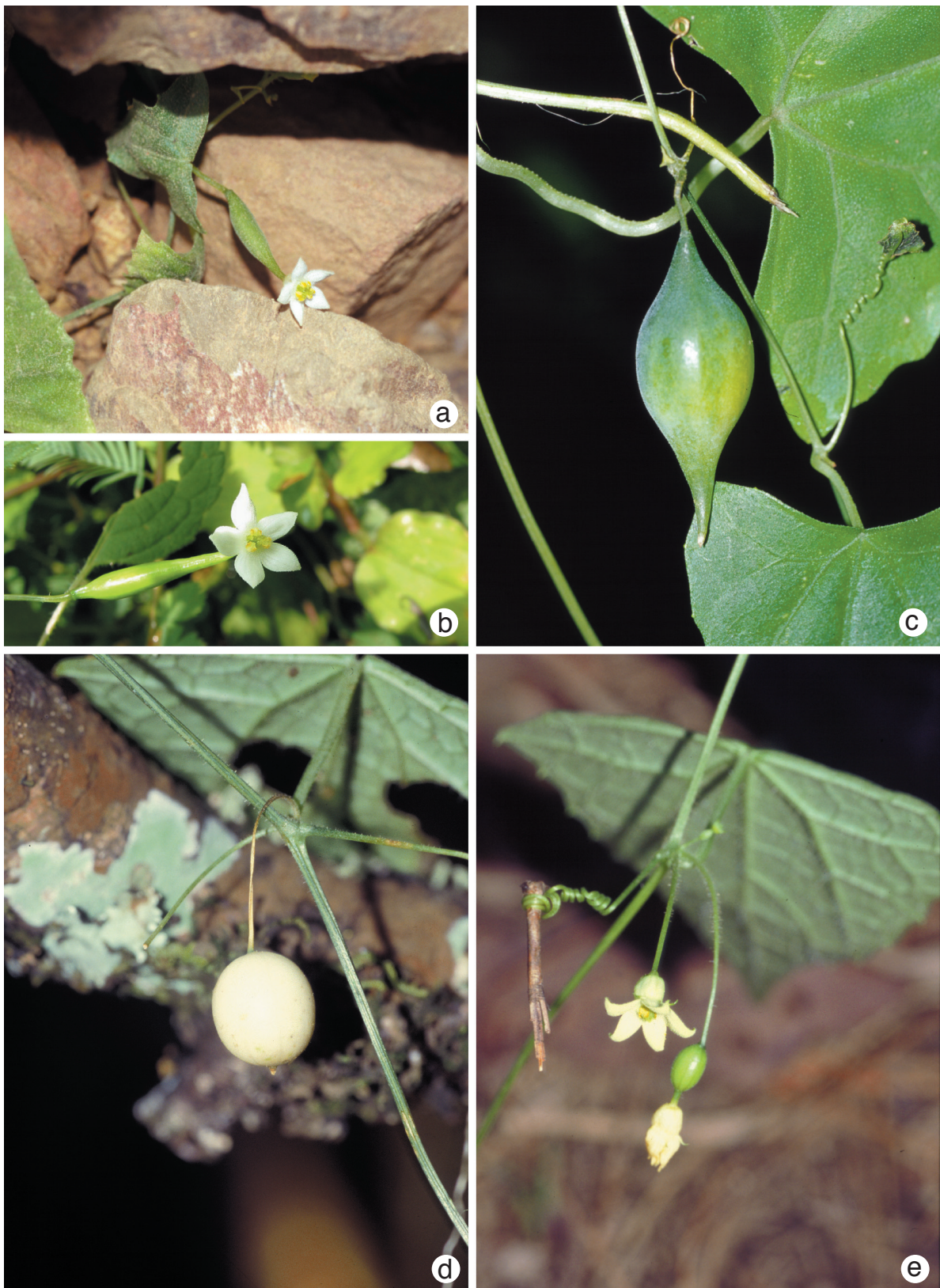

Plate 4. a-c. Neoachmandra hermaphrodita (W.J. de Wilde \& Duyfjes) W.J. de Wilde \& Duyfjes; d, e. Neoachmandra indica (Lour.) W.J. de Wilde \& Duyfjes (a: Khoonkhunthod et al. 330; b: Phonsena et al. 4652; c: De Wilde 22289; d, e: Somran et al. 2392). Photos De Wilde. 

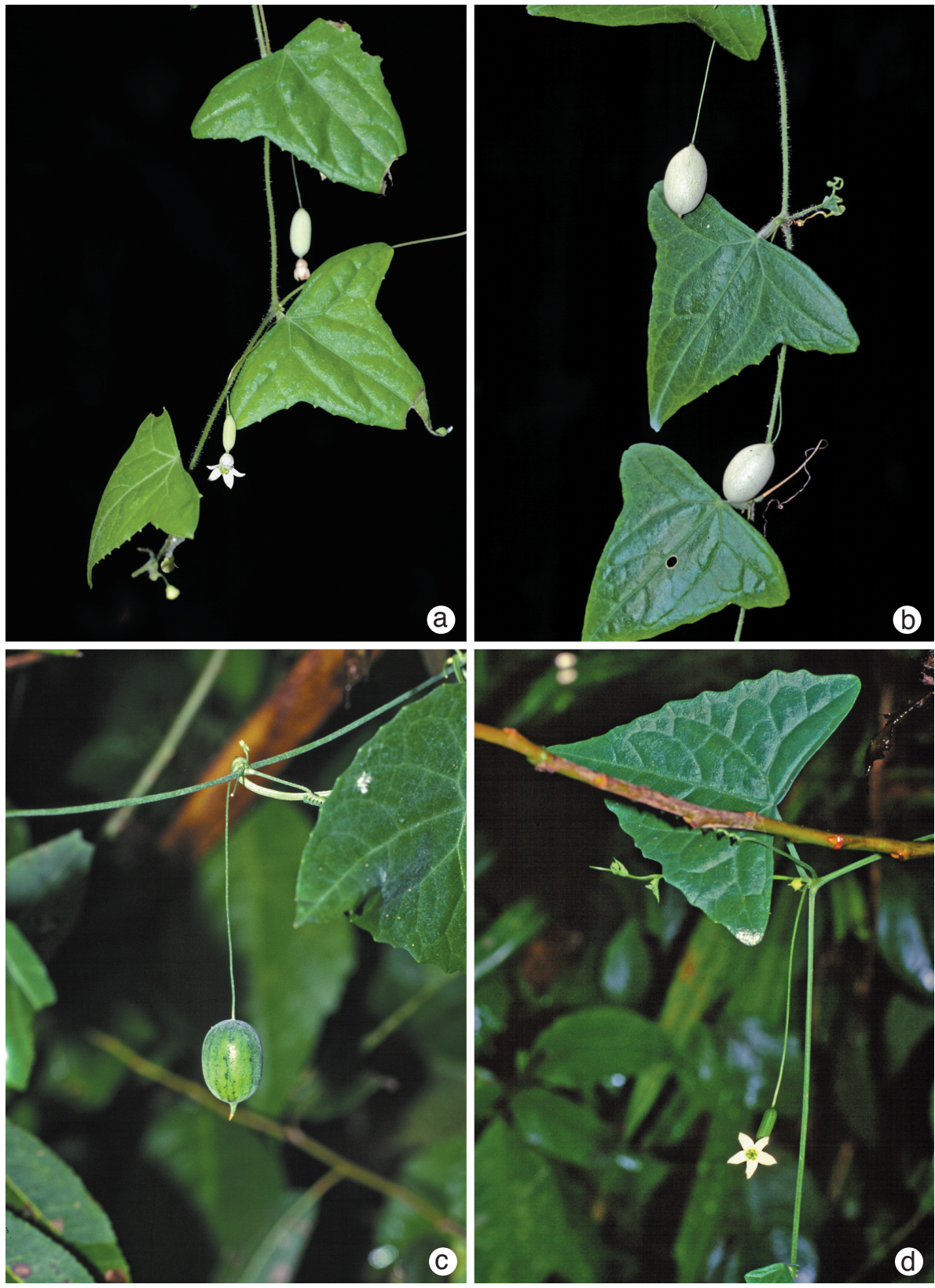

Plate 5. a, b. Neoachmandra leucocarpa (Blume) W.J. de Wilde \& Duyfjes; c, d. Neoachmandra nesophila W.J. de Wilde \& Duyfjes (a, b: De Wilde 21843; c, d: De Wilde 21935). Photos De Wilde. 

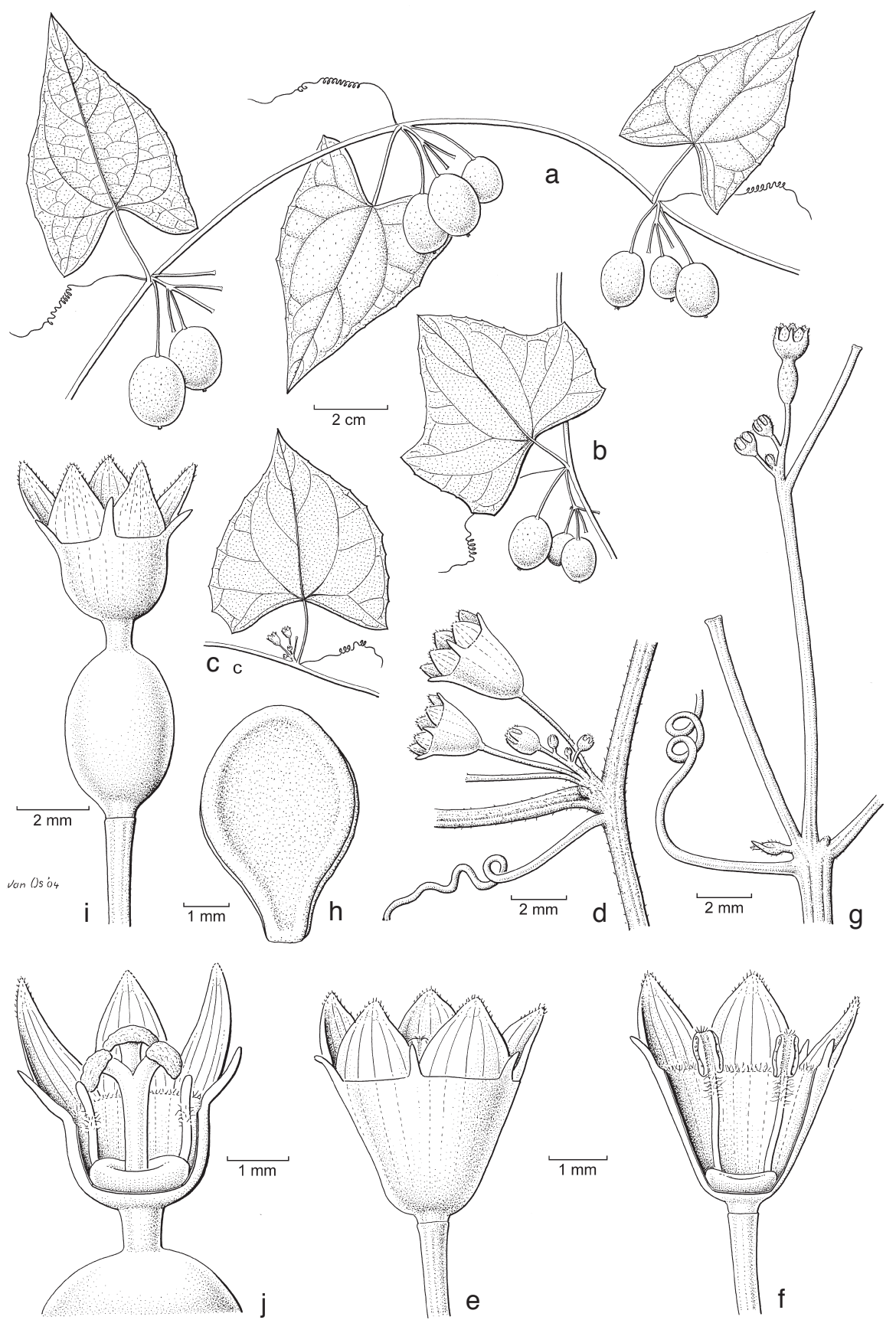

Fig. 13. a-h: Zehneria erythrobacca W.J. de Wilde \& Duyfjes. a, b. Branch with fruits; c, d. nodes with male inflorescences; e, f. male flowers; g. node with female inflorescences; h. seed. - i, j: Zehneria viridifolia W.J. de Wilde \& Duyfjes. Female flowers (a, g, h: Widjaja EAW 6961; b: Brass 2172, type; c-f: Brass 8104; i, j: Brass 23914). 
short raceme; pedicel 5-10 mm long; ovary ellipsoid(-fusiform), 3.5-6 by $1.5-3 \mathrm{~mm}$, glabrous (except for some glandular papillae), neck $0.5-1 \mathrm{~mm}$ long; style $1.5-3 \mathrm{~mm}$ long, stigma c. $2 \mathrm{~mm}$ diam., consisting of 3 lobes on $0.2-0.3 \mathrm{~mm}$ long style-arms; disc $0.5 \mathrm{~mm}$ high; staminodes inserted about halfway in the receptacle-tube, $0.5-1.5 \mathrm{~mm}$ long, glabrous or woolly hairy at apex. Fruits $1-3(-5)$ in loose fascicles; (subglobose-) ellipsoid, (1.3-) $1.5-2$ by $1-1.5 \mathrm{~cm}$; pericarp finely pitted or tessellated; fruiting pedicel 1-2.5 cm long. Seeds numerous, ovate, $4-5$ by $3-3.5 \mathrm{~mm}$, pale, not ornamented, margin narrow, edge square and often with a groove in the middle.

Field-notes - Leaves fleshy. Flowers white. Fruits red when ripe. Milliken 1315 reports: 'edible'.

Distribution - Throughout New Guinea and Bismarck Archipelago.

Habitat \& Ecology - Secondary forest, riverbanks, scrub-land; lowland to 1000 $(-1750) \mathrm{m}$ altitude; flowering and fruiting throughout the year.

Note - Zehneria erythrobacca is common in New Guinea where it largely seems to replace Z. mucronata. The latter is a common lowland species in most of Malesia. The fruits of $Z$. mucronata, which is a rare species in New Guinea, are green when ripe, turning red only when remaining for a longer time on the plant, a condition not mentioned on the field labels. The fruits of Z. erythrobacca are orange or red when ripe, a condition often recorded on the labels.

\section{Zehneria grayana (Cogn.) Fosberg \& Sachet}

Zehneria grayana (Cogn.) Fosberg \& Sachet (1981) 12. - Karivia samoensis A. Gray (1854) 643 [not Melothria samoensis A. Gray = Zehneria samoensis (A. Gray) Fosberg \& Sachet (1981) $12=$ Neoachmandra samoensis (A. Gray) W.J. de Wilde \& Duyfjes]; Seem. (1866) 103. - Melothria grayana Cogn. (1881) 591, p.p., excluding specimens from Tahiti; (1916) 91, p.p. - Lectotype (Fosberg \& Sachet, 1981): US exploring expedition s.n. (US), Samoa, without further locality.

Karivia samoensis A. Gray var. vitiensis A. Gray (1854) 643. - Zehneria grayana (Cogn.) Fosberg \& Sachet var. vitiensis (A. Gray) Fosberg \& Sachet (1981) 13. - Type: US exploring expedition s.n. (holo US, not seen), Fiji.

Melothria carnosula Cogn. (1908) 258. - Lectotype (here chosen): K. \& L. Rechinger 1597 (W), Samoa, Savaii Islands.

Zehneria mucronata auct. non (Blume) Miq.: A.C. Sm. (1981) 685.

Stout 4-10 m long vine; dioecious; stem 2-3 mm diam.; plant (sub) glabrous, brown or blackish on drying, or obscurely green. Leaves: blade ovate or subcircular, 5-15 by $3.5-11 \mathrm{~cm}$, entire or rarely shallowly 3-lobed to c. $1 / 5$ deep, base shallowly or deeply cordate, with broad (rarely narrow, in New Ireland and New Britain) sinus, apex acute-acuminate, mucronate, margin shallowly or deeply dentate, teeth up to $3 \mathrm{~mm}$ long, upper surface scabrous or not, (sub)glabrous, cystoliths present or absent, lower surface glabrous, nerves glabrous or with minute sparse hairs; petiole 2-4 $\mathrm{cm}$ long, (sub)glabrous. Male inflorescences: a dense short raceme, 2-5 mm long, clustered as in a subumbel, (rarely branched), subsessile or short- or long-peduncled, peduncle $0.4-5 \mathrm{~cm}$ long. Male flowers: pedicel 4-8(-10) $\mathrm{mm}$ long, with a joint up to $1.5 \mathrm{~mm}$ below the receptacle-tube; expanded perianth 5-7 $\mathrm{mm}$ diam.; receptacle-tube (2-)2.5-3.5 by 3-4 $\mathrm{mm}$, outside glabrous, at throat and in the upper-half densely hairy, hairs $0.2-0.5 \mathrm{~mm}$ long; sepals suberect (patent), 0.5-1 mm long, (sometimes larger and petal-like, up to 2 by $1.5 \mathrm{~mm}$, Solomon Islands), glabrous or sparsely hairy; petals narrowly triangular or elliptic, $2-3$ by $1.5-2 \mathrm{~mm}$, subacute or blunt, densely 

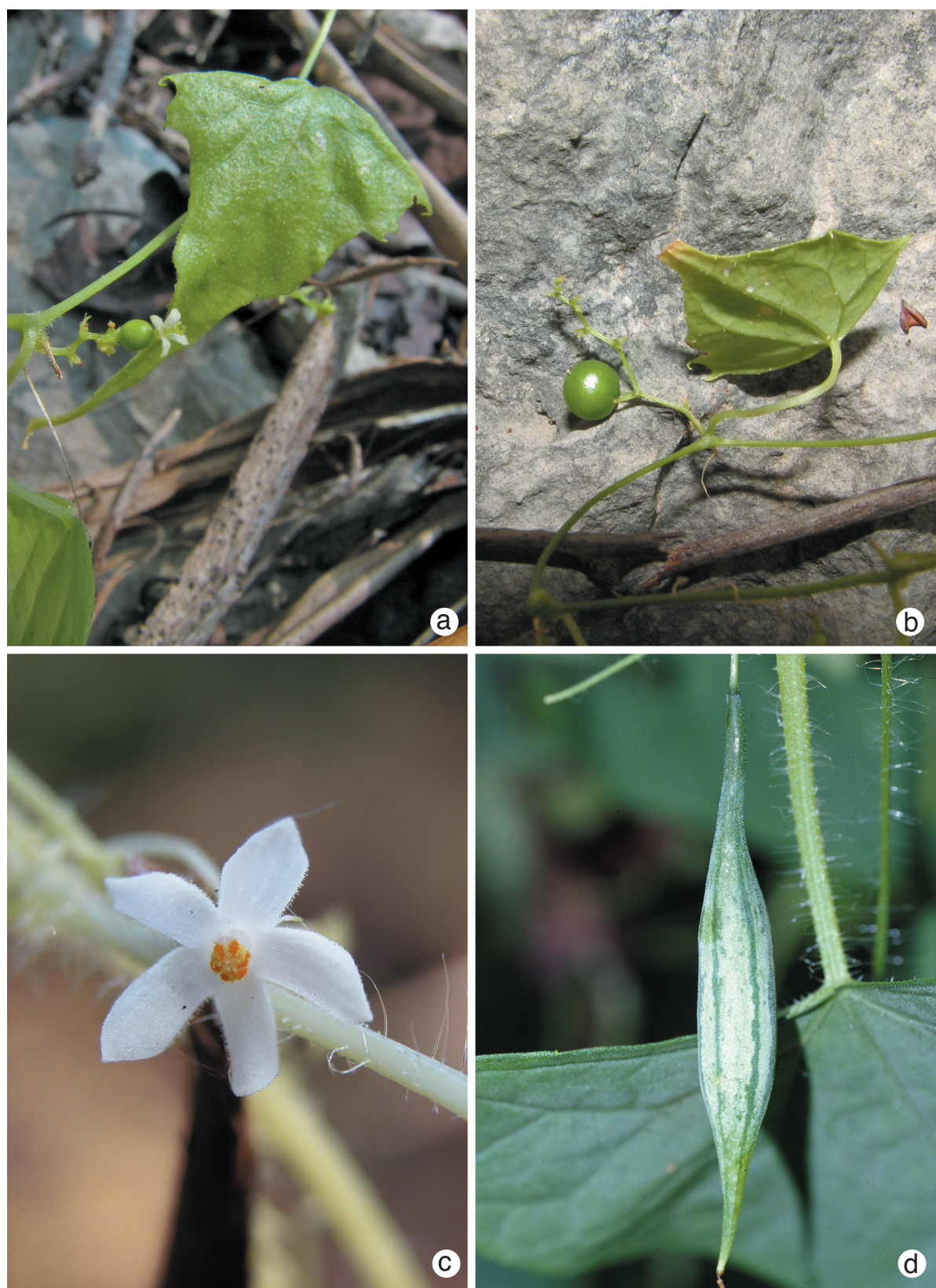

Plate 6. a, b. Neoachmandra sphaerosperma (W.J. de Wilde \& Duyfjes) W.J. de Wilde \& Duyfjes; c, d. Neoachmandra wallichii (C.B. Clarke) W.J. de Wilde \& Duyfjes (a, b: De Wilde 22303; c: Somran et al. 2285; d: De Wilde 22149) Photos: a, b, d: De Wilde; c: Thamarat Putthai. 

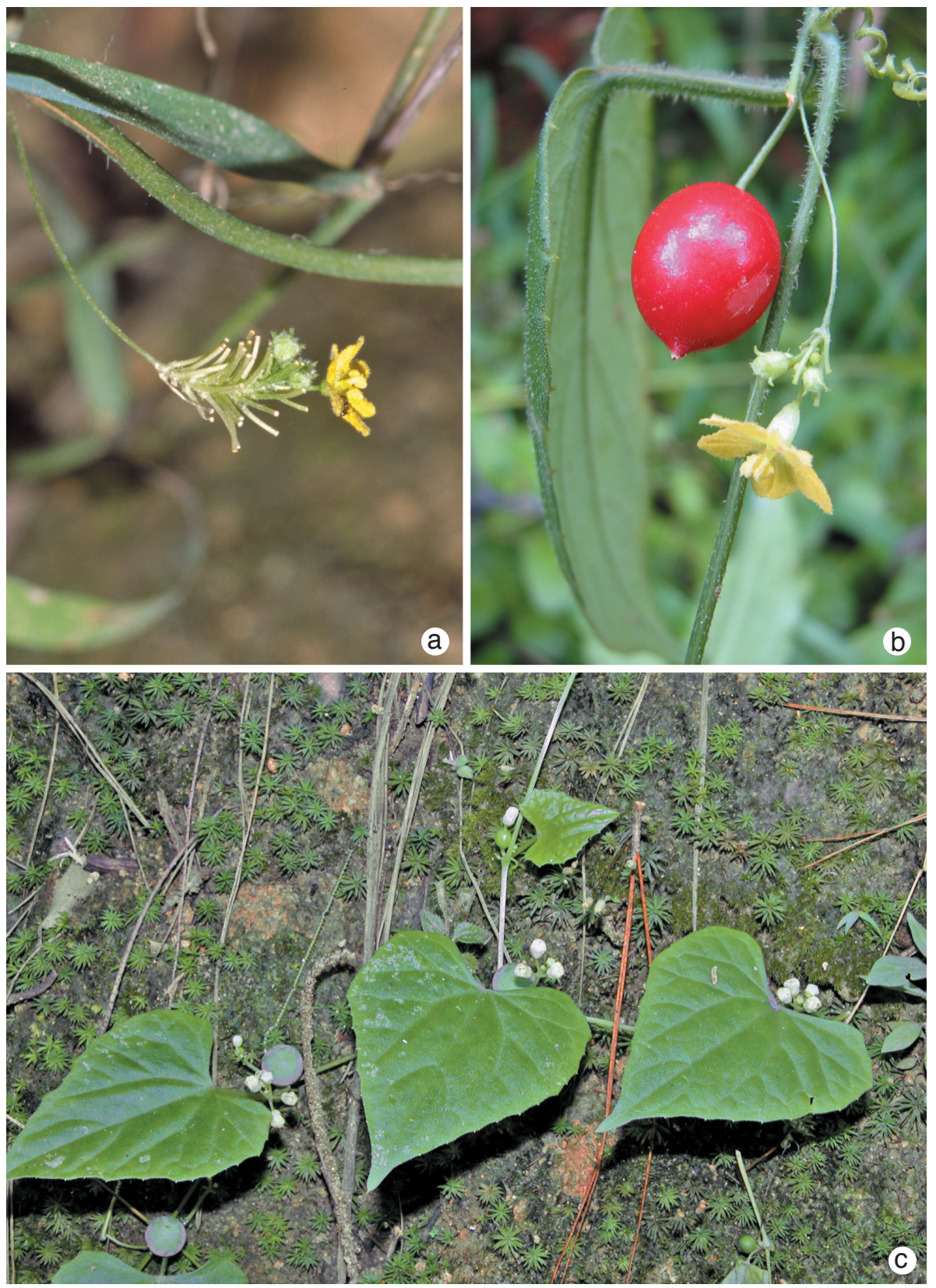

Plate 7. a, b. Scopella marginata (Blume) W.J. de Wilde \& Duyfjes var. marginata; c. Zehneria bodinieri (H. Lév.) W.J. de Wilde \& Duyfjes (a: Phonsena et al. 4457; b: Somran et al. 2307; c: Somran et al. 2519) Photos a, b: De Wilde; c: Thamarat Putthai. 
(papillose-)hairy outside at apex and wholly hairy inside (hairs $0.5-1 \mathrm{~mm}$ long); stamens inserted about halfway in the receptacle-tube, filaments $1.5-2 \mathrm{~mm}$ long, glabrous at apex and base but densely hairy over most of their lengths, hairs $0.5-1 \mathrm{~mm}$ long, anthers subcircular or broadly or narrowly elliptic in outline, 1.5-2 mm long, thecae curved and nearly touching at apex (Samoa) or \pm straight, connective broad (Samoa) or narrow, with stiff hairs lining the thecae; disc depressed half-globose, large, (0.5-)1 by (1-) $1.5-2.5 \mathrm{~mm}$, entire or faintly 3-lobed. Female flowers: solitary or up to 5 in a loose fascicle, sessile or up to $3 \mathrm{~cm}$ peduncled; pedicel $10-50 \mathrm{~mm}$ long when flowers solitary, 5-20 mm long when flowers fascicled; ovary (only seen in Green RSNH 1281, Vanuatu) narrowly ellipsoid, $8-10$ by $3 \mathrm{~mm}$, glabrous, neck short and broad, c. $2 \mathrm{~mm}$ long, perianth as in male flower but sepals longer, long-triangular, c. $1.5 \mathrm{~mm}$ long, \pm papillose-hairy; style c. $2.5 \mathrm{~mm}$ long, glabrous, stigma c. $2.5 \mathrm{~mm}$ diam., consisting of 3 papillose lobes c. $2 \mathrm{~mm}$ long, curved downwards, shortly connate at base; staminodes inserted halfway the receptacle-tube, $1-1.5 \mathrm{~mm}$ long, densely hairy, hairs $1 \mathrm{~mm}$ long, but apex glabrous; disc conspicuous, c. $1.5 \mathrm{~mm}$ high, irregularly shallowly 3-lobed. Fruit solitary with long pedicel (New Ireland) or 2-4 fruits in a peduncled fascicle, sometimes co-axillary with a solitary fruit; fruit (narrowly) ellipsoid, $2-4$ by $1-1.5 \mathrm{~cm}$, base and apex rounded or short-attenuate, glabrous, pale or dark brown on drying, red when ripe; pericarp not or faintly pitted; fruiting pedicel $0.5-5 \mathrm{~cm}$ long. Seeds numerous, $5-6$ by $3.5-4.5 \mathrm{~mm}$, whitish or pale brown, not ornamented, margin rather distinct, broad with rounded rim.

Distribution - New Ireland, New Britain, through the Solomon Islands, east to Vanuatu, Fiji (no specimens seen), and Samoa.

Habitat \& Ecology - Scrub and (shore) forest, rainforest edges, disturbed forest on slopes and in gullies; up to 1000 m altitude; flowering: mainly Augustus to October; fruiting throughout the year.

Notes -1 . Zehneria grayana is here conceived in a broad sense. It is widespread.

The sole specimen known from New Britain (Frodin NGF 26539) has male inflorescences but no flowers. It somewhat deviates in the narrow cordate leaf base.

Specimens may have scabrous (Solomon Islands) or smooth leaves and they may have smaller or larger male flowers (New Hebrides); their fruits may be fascicled with a common peduncle or solitary on a long, up to $5 \mathrm{~cm}$ long, fruiting pedicel. Resembling species regarded as distinct are Z. baueriana (Norfolk Islands, New Caledonia) and Z. tahitensis (Society Islands).

2. The sepals of Powell BSIP 19393 (Solomon Islands, San Cristóbal) are, possibly exceptionally, very large and petal-like.

3. According to Curry 1032 (Vanuatu) the fruits are edible.

\section{Zehneria guamensis (Merr.) Fosberg}

Zehneria guamensis (Merr.) Fosberg (in Fosberg \& Sachet, 1980) 15; B.C. Stone (1970) 565. - Melothria guamensis Merr. (1914) 151. - Type: Guam Experiment Station 11 (holo PNH $\dagger$; lecto (here chosen) E), Guam, Tumon.

Melothria liukiuensis Nakai (1938) 129. - Zehneria liukiuensis (Nakai) E. Walker (1971) 72; (1976) 1002; C. Jeffrey (1980a) 16. - Syntypes: Tashiro s.n., Myagi s.n., and Yazima s.n. (TI, not seen), Japan, Okinawa and Kôbitô.

Zehneria kelungensis Hayata (1921) 13, f. 7; C. Jeffrey (1980a) 16. - Type: Hayata s.n. (holo TI, not seen), Taiwan, Jilong. 
Distribution - Taiwan, Japan (Ryukyu Islands), Guam Island.

Note - This species has often been mixed up with Z. mucronata, which has a more southern distribution in Malesia. Zehneria guamensis is readily distinct by e.g. somewhat larger fruits, blackish when ripe, ultimately red in Z. mucronata.

\section{Zehneria hookeriana (Wight \& Arn.) Arn.}

Zehneria hookeriana (Wight \& Arn.) Arn. (1841) 275 . - Bryonia hookeriana Wight \& Arn. (1834) 345. - Type: Wight 1117 (holo K), S India.

Zehneria scabra auct. non (L.f.) Sond.: K.M. Matthew (1982) pl. 305.

Distribution - S India: Tamil Nadu and Madras; at 1600-2000 m altitude.

Note - As in Z. repanda, the young leaves of Z. hookeriana are often rusty-red hairy at the apex. Both species are montane; they probably evolved separately as montane ecotypes. Further study on their distinction is needed.

\section{Zehneria immarginata W.J. de Wilde \& Duyfjes, spec. nov.}

Zehneriae repandae similis, ovario fructu ellipsoideo longe pedicellato differt; a Z. erythrobacca in fructu minore c. $1 \mathrm{~cm}$ longo, semina minoribus c. $3 \mathrm{~mm}$ longis emarginatis. - Typus: Loeters 1580 (holo L), Indonesia, Flores.

Climber 1-3 m long; monoecious or dioecious; stem 1-2 mm diam.; plant subglabrous, dark on drying. Leaves: blade narrowly triangular or ovate-narrowly ellipsoid, 5-8 by $2-4.5 \mathrm{~cm}$, base shallowly or deeply cordate, margin finely or coarsely dentate, upper surface glabrous but scabrous by numerous small cystoliths, lower surface glabrous or (scabrid-)hairy on nerves; petiole 1-2.5 cm long, sparsely hairy. Male inflorescences: a peduncled raceme; peduncle 1-3 cm long, racemes short or long, sometimes with flowers \pm tiered, to 15 -flowered, up to $2 \mathrm{~cm}$ long. Male flowers: pedicel 4-6 mm long; expanded perianth 5-6 mm diam.; receptacle-tube c. 2 by $3 \mathrm{~mm}$, outside glabrous, inside densely woolly hairy, especially in the upper half, hairs $0.5-1 \mathrm{~mm}$ long; sepals c. $0.5 \mathrm{~mm}$ long; petals c. $2.5 \mathrm{~mm}$ long, outside papillose, inside hairy towards base; stamens inserted near the base of the receptacle-tube, filaments c. $2 \mathrm{~mm}$ long, glabrous, anthers just exserted, ellipsoid, 1-1.5 mm long, thecae somewhat curved, connective \pm narrow at apex; disc c. $1 \mathrm{~mm}$ diam., unlobed. Female flowers: solitary or few in subsessile short raceme; pedicel (5-)10-15 mm long; ovary ellipsoid-fusiform, 2.5-3 mm long, glabrous, neck c. $0.5 \mathrm{~mm}$ long; perianth as in male flower but somewhat larger, subglabrous, style 2-3 mm long, style-arms c. $1 \mathrm{~mm}$ long, stigma-lobes longer than broad, c. $1 \mathrm{~mm}$ long, papillose; staminodes $2-3 \mathrm{~mm}$ long; disc c. $0.5 \mathrm{~mm}$ high. Fruits solitary or $2-5$ in a subsessile fascicle, subglobose or ellipsoid, $0.8-1$ by $0.6-0.8 \mathrm{~cm}$, greyish; pericarp minutely pitted; fruiting pedicel $(0.5-) 1.5-2.5 \mathrm{~cm}$ long. Seeds numerous, compressed, ovate in outline, c. 3 by $2 \mathrm{~mm}$, not sculptured, smooth but sometimes very short-hairy at the ends, margin not apparent, edge rounded.

Field-note - Fresh ripe fruits have been recorded as pale yellowish.

Distribution - Lesser Sunda Islands: Lombok (Mt Rinjani), Flores (Mt Kelimoetoe, Mt Ranaha).

Habitat \& Ecology - Edges of Myrica scrub, grassy places, margins of Cusuarina forest; volcanic (lapilli) soils; at 2000-3500 m altitude; flowering and fruiting: March to June. 

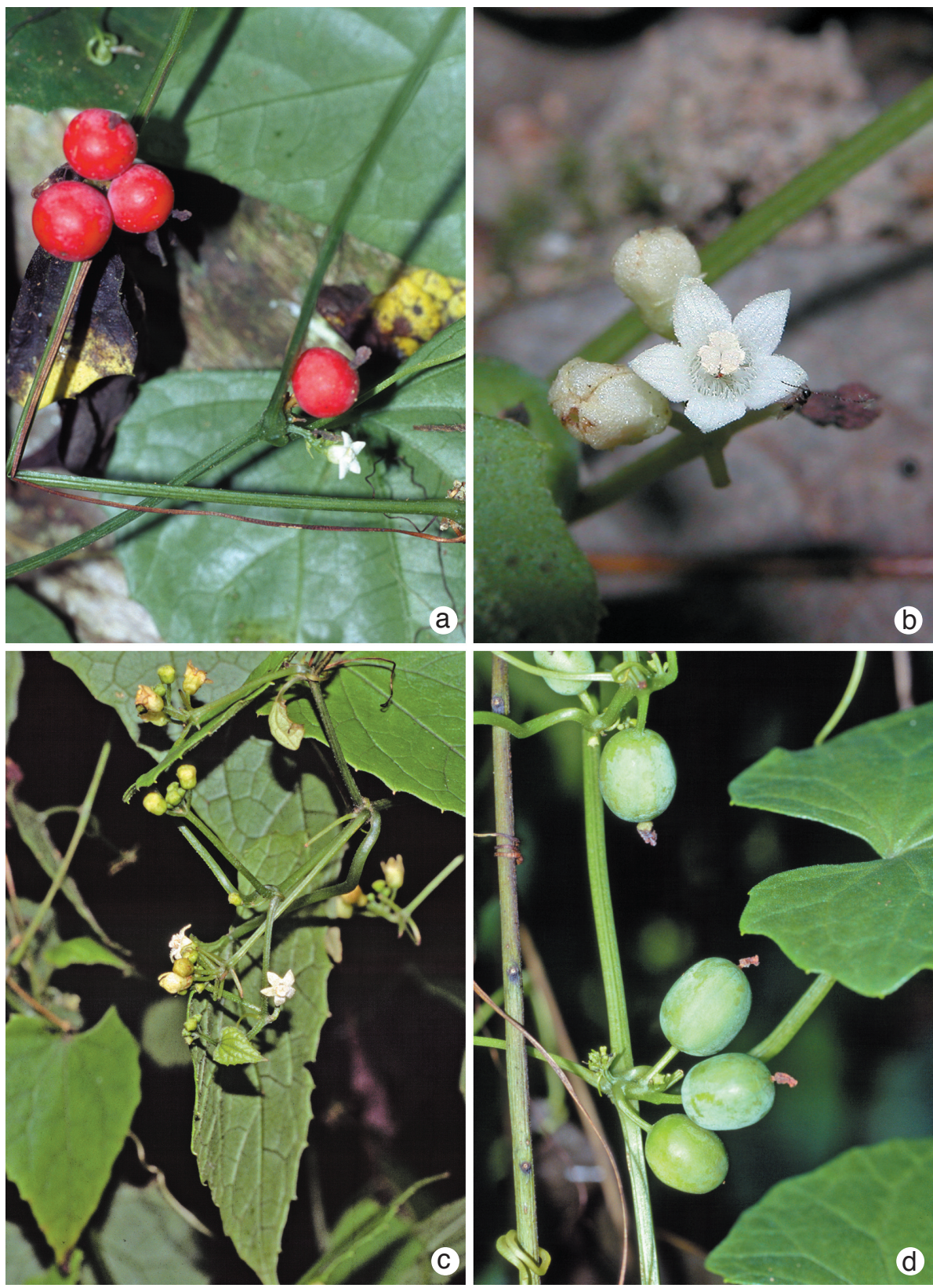

Plate 8. a, b. Zehneria bodinieri (H. Lév.) W.J. de Wilde \& Duyfjes; c, d. Zehneria mucronata (Blume) Miq. (a: SAN 141933; b: Somran et al. 2519; c: De Wilde 21727; d: De Wilde 22272). Photos: a, c, d: De Wilde; b: Thamarat Putthai. 
Notes -1 . This species reminds us in general habit of the more widespread Z. repanda from a similar habitat, which differs, e.g. in its short fruiting pedicel $0.3-0.6 \mathrm{~mm}$ long. Zehneria immarginata is distinct by the long-pedicelled fruits and the unmargined small seeds, with slightly convex faces. Unmargined seeds and long-pedicelled fruits are characters of the genus Neoachmandra, but Z. immarginata dries dark, and agrees furthermore with all features, including details of the male flowers, with the genus Zehneria.

Zehneria immarginata also resembles Z. pedicellata from mountainous New Guinea, the latter differs in globose fruits and somewhat larger, narrowly margined seeds.

2. The fruits of Kostermans \& Wirawan 733, from Flores, deviate in being small, less than $1 \mathrm{~cm}$ long; the collection approaches $Z$. perpusilla from the same area.

\section{Zehneria maysorensis (Wight \& Arn.) Arn.}

Zehneria maysorensis (Wight \& Arn.) Arn. (1841) 275 ('maysurensis'); W.J. de Wilde \& Duyfjes (2004) 28. - Bryonia maysorensis Wight \& Arn. (1834) 345. - Lectotype (here chosen): Wight $1116(\mathrm{~K}$; iso $\mathrm{P}), \mathrm{S}$ India.

Zehneria maysorensis (Wight \& Arn.) Arn. var. oblonga V.P. Prasad \& M. Prasad (1993) 471. - Type: Vivekananthan 45710 (holo MH, not seen), S India.

Distribution - Confined to southern Peninsular India, at low altitudes.

Note - This species, with a restricted area in S India, is apparently rare and has caused confusion with the montane $Z$. hookeriana with the same distributional area. Zehneria maysorensis is usually monoecious; its ovary and fruit is ellipsoid, longer than broad (dioecious and fruit globose in Z. hookeriana). The specific differences with the close Z. mucronata from Malesia need further study.

\section{Zehneria mucronata (Blume) Miq. - Fig. 14; Plate 8c, d}

Zehneria mucronata (Blume) Miq. (1856) 656; C. Jeffrey (1962) 371; (1980a) 16; I. Telford (1982) 182; C. Simmons \& W.J. de Wilde (2000) 237, f. 1. - Bryonia mucronata Blume (1826) 923 (incl. var.); Ser. (1828) 304 (incl. $\beta$ denticulata). - Melothria mucronata (Blume) Cogn. (1881) 608; (1916) 108; Backer (1964) 297. - Lectotype (Simmons \& De Wilde, 2000): Blume s.n. ("Pariagengie"), barcode L0048324 (L; iso L, 2 sheets) Java.

Zehneria alba Ridl. (1906) 195. - Melothria alba (Ridl.) Cogn. (1916) 109. - Type: Ridley s.n. (K, not seen), Christmas Island (Pacific Ocean).

Melothria lobata Merr. (1912) 104. - Type: Vanoverbergh 1241 (not seen).

Bryonia arguta Span. (1841) 206, nom. nud. - Voucher specimen: Zippelius s.n., barcode L0129472 (L), Timor.

Climber to $5 \mathrm{~m}$ long; usually dioecious, sometimes monoecious; stem 1-2(-3) $\mathrm{mm}$ diam.; plant finely hairy, glabrescent, dark on drying. Leaves: blade triangular or ovate, or \pm 5 -angular, (2-)4-8 by (2-)4-7 cm, entire or shallowly (deeply) lobed, base cordate with broad sinus, apex acute-acuminate, margin subentire or shallowly dentate, upper surface subglabrous, with cystoliths, lower surface subglabrous, but variously hairy on the nerves; petiole 1-5 cm long, (sparsely) scabrid. Male inflorescences: densely or loosely pedicelled racemes, occasionally proliferating; peduncle to $5 \mathrm{~cm}$ long. Male flowers: pedicel 2-5 mm long; expanded perianth 3-5 mm diam.; receptacle-tube 2.5-4 by $2-3.5 \mathrm{~mm}$, outside glabrous or with sparse hairs, inside variously hairy; sepals $0.5-1$ $\mathrm{mm}$ long; petals 2-3 mm long, minutely hairy inside; stamens inserted near the base of 


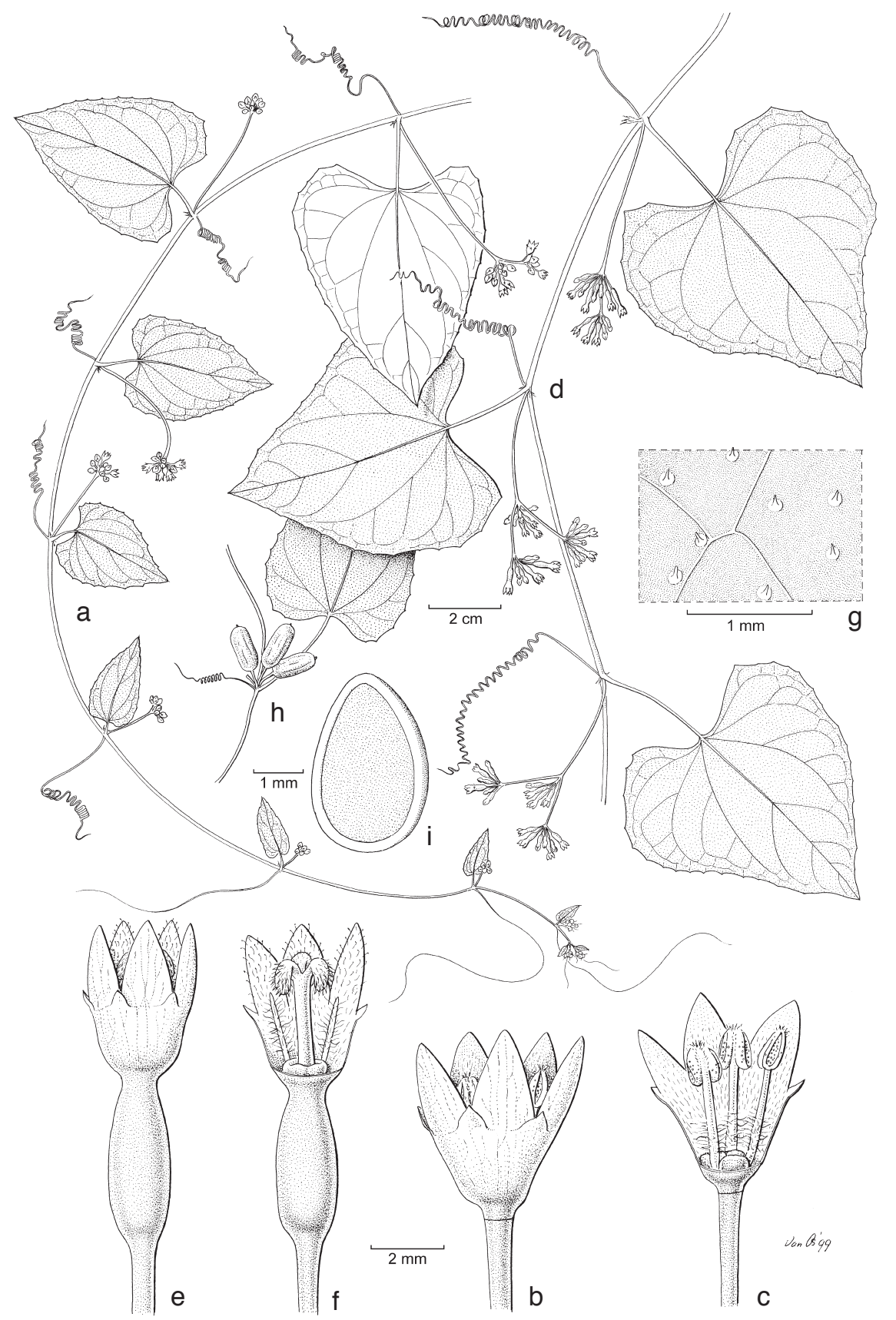

Fig. 14. Zehneria mucronata (Blume) Miq. a. Twig with male inflorescences; b, c. male flowers; d. twig with female inflorescences; e, f. female flowers; g. portion of upper leaf surface, with cystoliths; h. node with sessile infructescence; i. margined seed (a-c: De Wilde \& Duyfjes 21727; d-g: De Wilde \& Duyfjes 21728; h, i: Backer 36679). 
the receptacle-tube, 2(-3) mm long, filaments completely hairy or at least in the lower half, anthers somewhat longer than broad, c. $1 \mathrm{~mm}$ diam., thecae straight or \pm curved, connective narrow, \pm hairy, not protruding at apex; disc depressed globose, sometimes faintly 3-lobed, c. $1 \mathrm{~mm}$ diameter. Female flowers: in few- (or many-)flowered, sessile or peduncled clusters, occasionally mixed with male flowers; pedicel 1-2(-5) mm long; ovary narrowly ovoid-ellipsoid, $2-3 \mathrm{~mm}$ long, at apex narrowed into a neck, c. $1 \mathrm{~mm}$ long, glabrous; style 2-2.5 mm long, stigma c. $2 \mathrm{~mm}$ diam., consisting of 3 papillosehairy lobes; staminodes linear, variously hairy; disc c. $0.5 \mathrm{~mm}$ high. Fruits (1-)2-6 per cluster, subglobose, ellipsoid or narrowly ellipsoid, 1-1.5 cm long, apex rounded with minute point; pericarp minutely pitted, glabrous; living fruits green, ultimately red; fruiting pedicel $0.2-0.5(-1) \mathrm{cm}$ long. Seeds numerous, ovate-elliptic, 3-4(-5) mm long, whitish or pale brown, smooth, margin narrow but distinct.

Distribution - West Malesia: from Sumatra through Java (also Christmas Island) and the Philippines east to New Guinea and NE Australia (Telford, 1982, no specimens seen); no records from Peninsular Malaysia and Borneo.

Habitat \& Ecology - In scrub and forest edges, up to 1600(-2000) m altitude; flowering and fruiting throughout the year.

Notes -1 . Zehneria mucronata resembles Z. maysorensis, an insufficiently known species from $S$ India, similar in ellipsoid fruits. The latter differs in its usually single fruit, co-axillary with male inflorescence. However, this latter condition is occasionally also found in Z. mucronata from Papua New Guinea, e.g. in Darbyshire 197.

2. Zehneria alba was described as endemic to Christmas Island, distinct by large $4 \mathrm{~mm}$ long male petals, and glabrous filaments. We have not seen the type, but in two other collections from Christmas Island, Andrews s.n. and Mitchell M 21, the male flowers are smaller (petals only $2 \mathrm{~mm}$ long) and the filaments hairy.

\section{Zehneria neocaledonica W.J. de Wilde \& Duyfjes, spec. nov. - Fig. 15}

Vitis ad 3 metra longa dioecia. Inflorescentia masculina racema multiflora sessilis 5 ad $10 \mathrm{~mm}$ longa 1 vel 2 unoquoque nodo; flores masculinis c. $3 \mathrm{~mm}$ longi. Semina c. $3 \mathrm{~mm}$ longa dense pubescentia. - Typus: Däniker 3139 (holo L; iso Z, not seen).

Vine 2-3 m long, creeping or climbing; dioecious; stem 1-2 mm diam.; plant glabrous (few minute hairs on growing apex), green on drying. Leaves: blade broadly or narrowly ovate, $4-6$ by $2.5-5 \mathrm{~cm}$, entire or faintly lobed or subhastate, base cordate, apex acute, margin 1(-2) mm serrate-dentate, upper surface with minute cystoliths; petiole 1-3 cm long. Male inflorescences: densely 10-30-flowered condensed 5-10 $\mathrm{mm}$ long racemes, 1 or 2 per node, glabrous, except for the flower buds. Male flowers: pedicel 2-3 mm long; expanded perianth c. $4 \mathrm{~mm}$ diam.; receptacle-tube c. 1.5 by $2-2.5$ $\mathrm{mm}$, outside glabrous, throat densely hairy, hairs $0.5 \mathrm{~mm}$ long; sepals $0.5-1 \mathrm{~mm}$ long, suberect; petals c. $2 \mathrm{~mm}$ long, outside minutely papillose; stamens inserted at the base of the receptacle-tube, filaments c. $1.5 \mathrm{~mm}$ long, densely hairy in the upper half, hairs $0.5 \mathrm{~mm}$ long, anthers erect, 1 by $0.7 \mathrm{~mm}$, thecae straight, connective narrow, with few minute stiff hairs; disc depressed globose, $1 \mathrm{~mm}$ diameter. Female flowers not seen. Fruit solitary, (narrowly) ellipsoid, $1.5-2.5$ by $0.8-1 \mathrm{~cm}$, grey-brown, glabrous; pericarp thin, not pitted; fruiting pedicel $0.4-1 \mathrm{~cm}$ long. Seeds numerous, ovate, not much compressed, $3-3.5$ by $2-2.3$ by $0.5-0.8 \mathrm{~mm}$, densely appressed-hairy, hairs silky grey or pale brown-yellow, $0.3 \mathrm{~mm}$ long, not ornamented, without margin. 


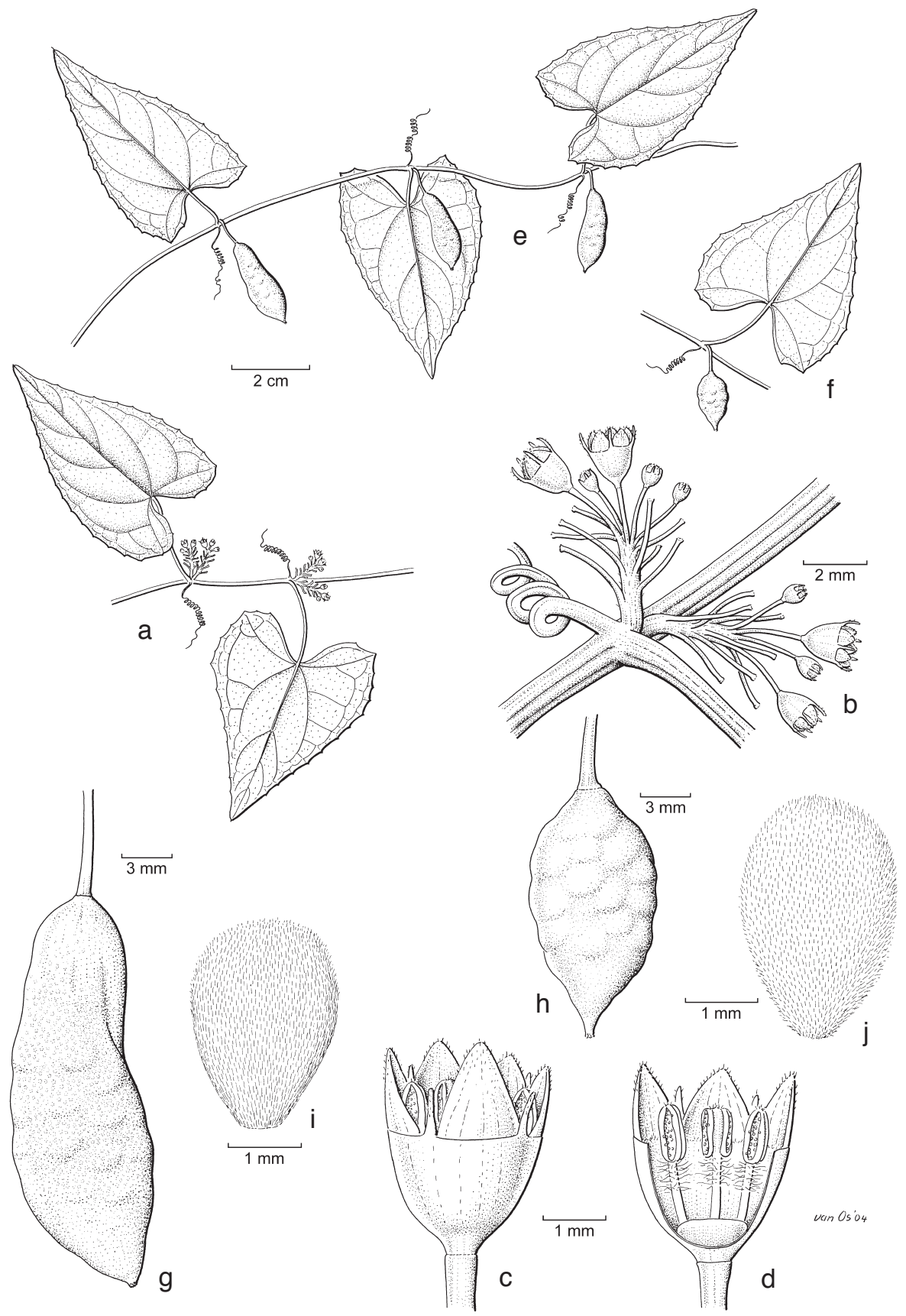

Fig. 15. Zehneria neocaledonica W.J. de Wilde \& Duyfjes. a. Portion of shoot with male inflorescences; b. male inflorescences; c, d. male flower, just opened; e, f. portions of twigs with fruits; $\mathrm{g}$, h. fruits; i, j. hairy seeds (a-d, f, h, j: Däniker 3139, type; e, g, i: Baumann-Bodenheim 8895). 
Distribution - Endemic to New Caledonia.

Habitat \& Ecology - In damp forest, and in sand dune area; lowland; flowering and fruiting: August to November.

Note - This is a remarkable species, green on drying, with small flowers and small seeds. According to the male inflorescences and flowers it clearly belongs to Zehneria, but the green drying colour of the plant and the non-pitted thin pericarp suggest affinity with Neoachmandra. The seed is quite remarkable because it is distinctly hairy, as found also in Indomelothria.

Specimens examined:

Däniker 3139 (type); Guillaumin 8895.

\section{Zehneria pedicellata W.J. de Wilde \& Duyfjes, spec. nov.}

Zehneriae repandae similis, floribus feminis fructibusque longe pedicelatis distincta. Fructus globosus 6-8 $\mathrm{mm}$ diam. niger, pedicellus in fructu $15-25 \mathrm{~mm}$ longus. - Typus: Brass 30732 (holo L; iso K), Papua New Guinea.

Creeper or climber, 2-4 m long; dioecious; stem 1(-2) mm diam.; plant sparsely fine-hairy, glabrescent, blackish brown on drying. Leaves: blade narrowly triangular or (narrowly) ovate, $4-7$ by $1.5-3.5 \mathrm{~cm}$, base shallowly cordate with broad sinus, apex long acuminate, margin shallowly (deeply) dentate, not lobed, both surfaces glabrous or the nerves variously scabrid-hairy, upper surface with cystoliths; petiole $0.5-1(-2) \mathrm{cm}$ long, subglabrous. Male inflorescences: peduncled racemes, peduncle slender, $3-7 \mathrm{~cm}$ long, raceme 2-3 mm long, with up to 10 flowers, clustered in a condensed subumbel. Male flowers: pedicel 5-10 mm long; expanded perianth c. $4 \mathrm{~mm}$ diam.; receptacle-tube c. 1.5 by $2-2.5 \mathrm{~mm}$, glabrous but throat minutely sparsely hairy; sepals $0.5 \mathrm{~mm}$ long, suberect; petals (long-)triangular, c. $1.5 \mathrm{~mm}$ long, outside minutely papillose-hairy; stamens inserted at the base of the receptacle-tube, filaments c. $1.5 \mathrm{~mm}$ long, glabrous, anthers subglobose, c. $1.5 \mathrm{~mm}$ diam., thecae half-circular, almost touching at both ends, nearly horizontal, connective broad in the middle, convex, minutely hairy along the thecae; disc c. $1.5 \mathrm{~mm}$ diam., deeply 3-lobed, lobes half-globose. Female flowers: solitary; pedicel 10-25 mm long; ovary globose, 2-3 mm diam., glabrous, neck c. 2 $\mathrm{mm}$ long; perianth as in male flower but longer, receptacle-tube c. 2 by $3.5(-4) \mathrm{mm}$, throat finely woolly hairy; style c. $2.5 \mathrm{~mm}$ long, glabrous, stigma c. $1.5 \mathrm{~mm}$ diam., consisting of 3 arms $0.3 \mathrm{~mm}$ long, each bearing a subglobose papillose stigma-lobe 0.5-0.7 mm diam.; staminodes distinct, subulate, c. $2 \mathrm{~mm}$ long, glabrous; disc c. $1 \mathrm{~mm}$ high, deeply 3-lobed. Fruit solitary at the node, globose, $0.6-0.8 \mathrm{~cm}$ diam., blackish, faintly minutely pitted, glabrous; perianth not persistent but flower-neck remaining as a minute beak at apex; fruiting pedicel $1.5-2.5 \mathrm{~cm}$ long. Seeds rather numerous, ovate-elliptic, c. 4 by $3 \mathrm{~mm}$, not ornamented, margin narrow but distinct.

Field-notes - Mature fruits blackish. Vinas UPNG 4874 recorded the flowers as yellow, but this can be doubted as the petals are white or creamy in Zehneria.

Distribution - Papua New Guinea, Western and Eastern Highlands Provinces.

Habitat \& Ecology - Forest edges and secondary growth; riverbanks; at 2000$2700 \mathrm{~m}$ altitude; flowering and fruiting throughout the year.

Notes -1 . Zehneria pedicellata is in habit similar to Z. pisifera. The latter differs in a much shorter fruiting pedicel, c. $1.5 \mathrm{~cm}$ long or less. 
2. In Vinas UPNG 4874 the leaves are more conspicuously dentate compared with the rest of the collections.

3. Female specimens, with solitary, long-pedicelled flowers or fruits may be confused with members of the genus Neoachmandra; the latter genus is monoecious, with the male flowers few or solitary, not as in the present species in a peduncled raceme.

Specimens examined:

Borgmann 256; Brass 30726, 30732 (type); Sterly 80 471; Vinas UPNG 4874.

\section{Zehneria perpusilla (Blume) Bole \& M.R. Ameida}

Zehneria perpusilla (Blume) Bole \& M.R. Almeida (1983) 315 (for the type only); C. Simmons \& W.J. de Wilde (2000) 238. - Cucurbita perpusilla Blume (1823) 105. - Bryonia perpusilla (Blume) Blume (1826) 926; Miq. (1856) 660. - Bryonia stipulacea Willd. $\beta$ perpusilla (Blume) Ser. (1828) 307. - Melothria perpusilla (Blume) Cogn. (1881) 607; (1916) 106; Backer (1964) 297, p.p. - Zehneria scabra auct. non (L.f.) Sond.: C. Jeffrey (1962) 369, p.p., for the synonym Melothria perpusilla (Blume) Cogn. only. - Lectotype (Simmons \& De Wilde, 2000): Blume s.n., barcode L0048312 (L; iso L, 4 sheets), Java.

Cucurbita scabra Blume (1823) 105, non Bryonia scabra L.f., 1781. - Bryonia scabrata Blume (1826) 923; Ser. (1828) 304; Miq. (1856) 659. — Lectotype (Simmons \& De Wilde, 2000): Blume s.n. (“Korreg Kottok"), barcode L0048319 (L; iso L), Java, Salak.

Climber 2-3 m long; monoecious or dioecious; stem 1-2 mm diam.; plant subglabrous, brownish blackish on drying. Leaves: blade triangular or ovate, $4-10$ by 3-7 cm, entire or 3(-5)-lobed and irregular in shape with the lobes up to halfway, base (deeply) cordate, apex acute-acuminate, margin coarsely or finely (serrate-)dentate, upper surface scabrous with cystoliths, lower surface (sub)glabrous; petiole 1-5 cm long, subglabrous. Male inflorescences: subsessile or to $1 \mathrm{~cm}$ (in Lesser Sunda Islands to 3 $\mathrm{cm}$ ) long peduncled short racemes, rather few-flowered (sometimes proliferating in Lesser Sunda Islands), mixed with few female flowers or not, and often with a single female flower co-axillary. Male flowers: pedicel 3-5 mm long; expanded perianth 3-4 mm diam.; receptacle-tube c. 1.5 by $1.5 \mathrm{~mm}$, outside glabrous, throat and inside woolly hairy; sepals less than $0.5 \mathrm{~mm}$ long, erect; petals (narrowly) triangular, 1.5-2 mm long, \pm hairy at both surfaces; stamens inserted near the base of the receptacletube, filaments c. $1.5 \mathrm{~mm}$ long, long-woolly hairy at and below the middle, anthers subcircular, $1 \mathrm{~mm}$ diam., thecae curved, connective rather broad in the middle, hairy; disc $1 \mathrm{~mm}$ diam., deeply 3-lobed, lobes half-globose. Female flowers: in the same way disposed as male flowers; pedicel $2-5 \mathrm{~mm}$ long; ovary globose, c. $2 \mathrm{~mm}$ diam., glabrous, neck $1 \mathrm{~mm}$ long; style c. $2.5 \mathrm{~mm}$ long, slender, glabrous, stigma $1 \mathrm{~mm}$ diam., deeply 3-lobed; staminodes c. $1.5 \mathrm{~mm}$ long, woolly hairy in upper half; disc $0.5 \mathrm{~mm}$ high, 3-parted. Fruits solitary or 2-5 in a sessile to $1 \mathrm{~cm}$ long peduncled cluster; fruit globose, $0.6-0.8 \mathrm{~cm}$ diam., greenish, faintly finely pitted; fruiting pedicel c. $0.5 \mathrm{~cm}$ long. Seeds 5-10, flat, elliptic, 2.5-3.5 mm long, with narrow margin.

Distribution - W Java, Salayar Island, Lesser Sunda Islands: (?Bali), Lombok, Sumbawa, Flores.

Habitat \& Ecology - Lower montane area, in forest edges and low scrub; at (300-)500-1000 $\mathrm{m}$ altitude; flowering and fruiting throughout the year.

Note - In a previous publication on Zehneria in Java (Simmons \& De Wilde, 2000) Z. perpusilla was accepted as a not well-defined species beside Z. mucronata and 
Z. repanda. Zehneria perpusilla seems closer to Z. repanda because both have rounded anthers with curved more or less horizontal thecae, and a more or less convex connective. In the Lesser Sunda Islands a division of Zehneria into 3 taxa can be made, viz. Z. mucronata, Z. repanda, and a more or less intermediate form. This intermediate form differs in details from the limited material available of $Z$. perpusilla from West Java (Mt Salak), but still warrants its inclusion in that species. It is likely that the differences of these 3 feebly defined species are (at least partly) ecotypic, and they may hybridize as well. Consequently, a part of the collections cannot be determined with certainty. Similar specimens, but with thickish (not flat) unmargined seeds have been described as a separate species, Z. immarginata.

14. Zehneria pisifera W.J. de Wilde \& Duyfjes, spec. nov. - Fig. 16, 17

Omnibus congeneribus in floribus minutis c. $3 \mathrm{~mm}$ diam., fructu globoso c. $0.5 \mathrm{~cm}$ diam. in racemis pedunculatis depositis distincta. - Typus: Brass 29609 (holo L; iso K), Papua New Guinea.

Melothria cissybium M. Jacobs (1954) 617, f. 2, p.p., excluding the type which is Urceodiscus belensis.

Climber 0.5-2 m long; monoecious; stem $1 \mathrm{~mm}$ diam.; plant sparsely hairy, early glabrescent, blackish on drying. Leaves: blade triangular or ovate, $3-8$ by $1.5-5 \mathrm{~cm}$, base subtruncate or cordate, with broad sinus, apex (long) acuminate, margin entire, variously dentate, rarely (shallowly) lobed-dentate, upper surface (sub) glabrous, with cystoliths, lower surface variously scabrid along the nerves or subglabrous; petiole 1-3.5 cm long, scabrid or subglabrous. Male inflorescences: $2-5 \mathrm{~cm}$ long peduncled, slender, spike-like racemes 3-4 cm long (flowers in young inflorescences fewfascicled at the end of the peduncle but later proliferating), flowers frequently 2-5tiered, but also dispersed, commonly mixed with female flowers. Male flowers: pedicel 2-3 mm long, perpendicular to the rachis; expanded perianth 3-4 mm diam.; receptacletube $1.2-1.5$ by $2.2-3 \mathrm{~mm}$, glabrous, throat minutely hairy inside; sepals $0.3-0.5 \mathrm{~mm}$ long, erect, at base connected by a line or low rim; petals triangular, $1-1.5$ by $1-1.5 \mathrm{~mm}$, outside minutely hairy; stamens inserted near the base of the receptacle-tube, filaments 1-1.5 mm long, glabrous, anthers subglobose, $0.5 \mathrm{~mm}$ diam., thecae curved, nearly horizontal, connective broad in the middle, convex and with minute hairs adaxially; disc 1 by $1.5 \mathrm{~mm}$, consisting of 3 rounded lobes. Female flowers: in the same way disposed as the male flowers, and frequently mixed with them; pedicel $3-5(-7) \mathrm{mm}$ long; ovary globose, 1.5-2 mm diam., glabrous, neck $0.5(-1) \mathrm{mm}$ long; style 1(-1.5) $\mathrm{mm}$ long, glabrous, stigma consisting of 3 down-curved papillose lobes, in all $1 \mathrm{~mm}$ diam.; staminodes distinct, inserted near the base of the receptacle-tube, subulate, $1 \mathrm{~mm}$ long, glabrous; disc $0.3 \mathrm{~mm}$ high, faintly lobed. Fruits 1 (or 2) at the node or usually several in the spike-like inflorescence, often when still proliferating and producing flowers at the apex; fruit globose, $0.5-0.7 \mathrm{~cm}$ diam., green, pale yellow or red, when dry pale brown, glabrous, withered perianth persisting; pericarp not or faintly pitted; fruiting pedicel $0.2-0.6 \mathrm{~cm}$ long. Seeds c. 10, elliptic, c. 2.5 by $1.5 \mathrm{~mm}$, pale brown, not ornamented, margin narrow, faint.

Field-notes - Corolla valvate, yellow. Fruits spherical, said to be edible; exocarp red when ripe (Takeuchi 10518). Flowers yellow (Pullen 427). 


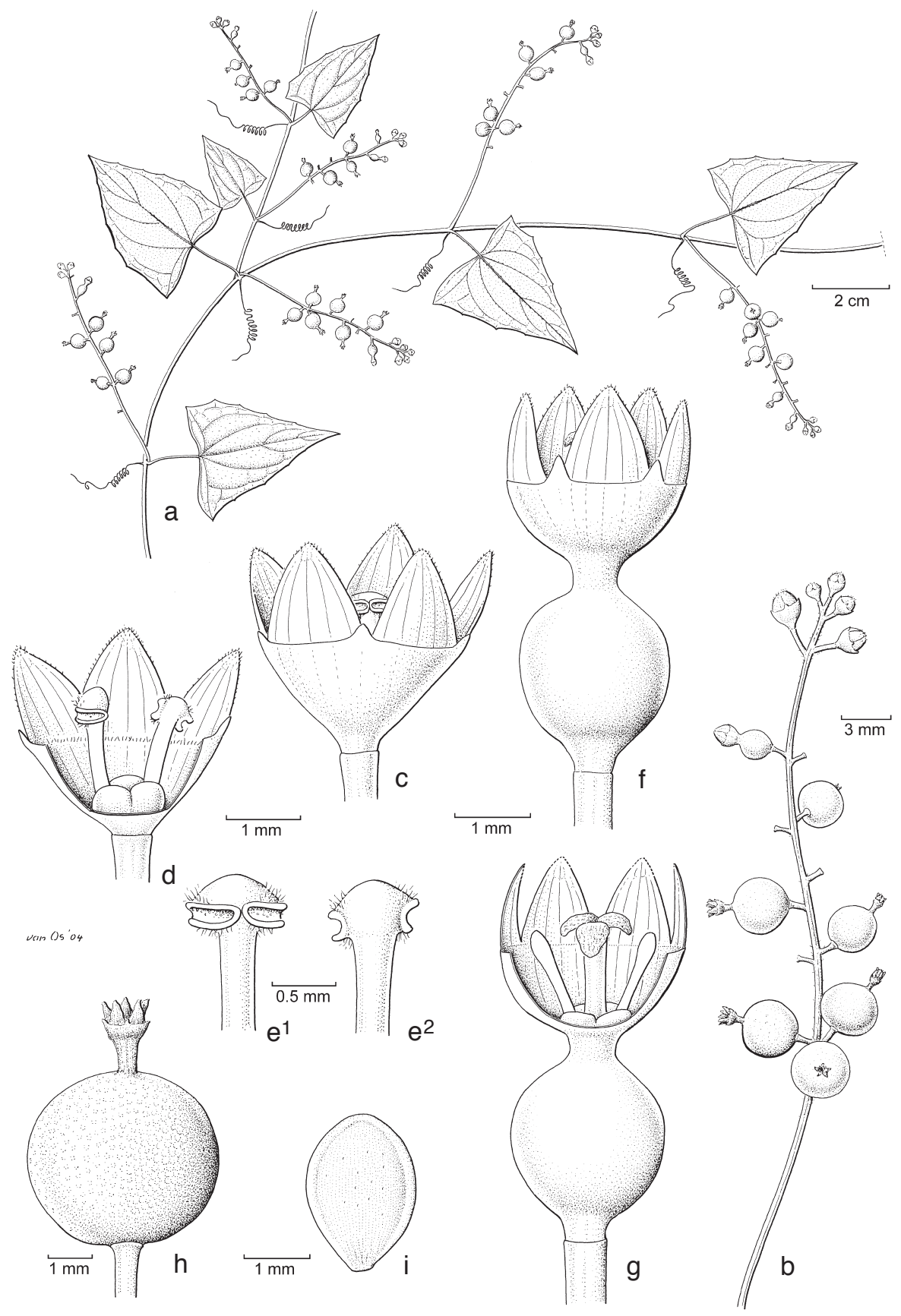

Fig. 16. Zehneria pisifera W.J. de Wilde \& Duyfjes. a. Twig with inflorescences; b. inflorescence, enlarged, showing fruits, and at apex one female flower and male flowers; c, d. male flowers; $\mathrm{e}^{1}, \mathrm{e}^{2}$. anthers, ab- and adaxially, respectively; f, g. female flowers; h. fruit with withered perianth; i. seed (all: Hoogland \& Pullen 5926). 


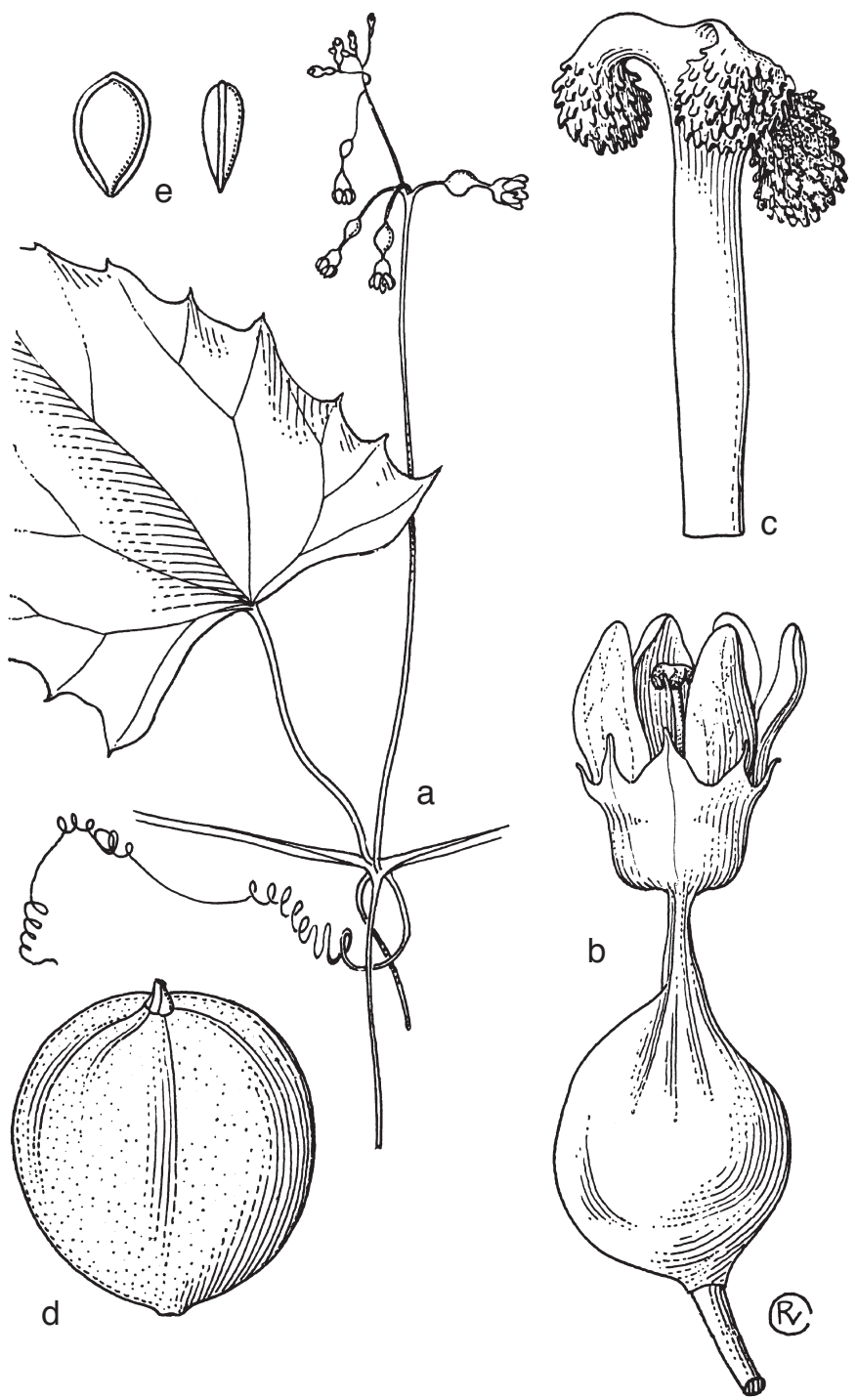

Fig. 17. Zehneria pisifera W.J. de Wilde \& Duyfjes. a. Node with inflorescence $(\times 1)$; b, c. female flower $(\times 7)$ and style $(\times 20)$ with stigmas after anthesis; $d$. fruit $(\times 4)$; e. seeds $(\times 4)($ all: Womersley 5364).

Distribution - Eastern part of mountainous Papua New Guinea, Western, Southern and Eastern Highlands Provinces, Morobe and Central Provinces.

Habitat \& Ecology - Grassy places, scrub and open Nothofagus forest; at 1400$2700 \mathrm{~m}$ altitude; flowering and fruiting: May to December.

Note - Fruits have been recorded as pale yellow or also as unripe and green, but such green fruits appear to contain mature seeds. The persistent perianth dries blackish. 


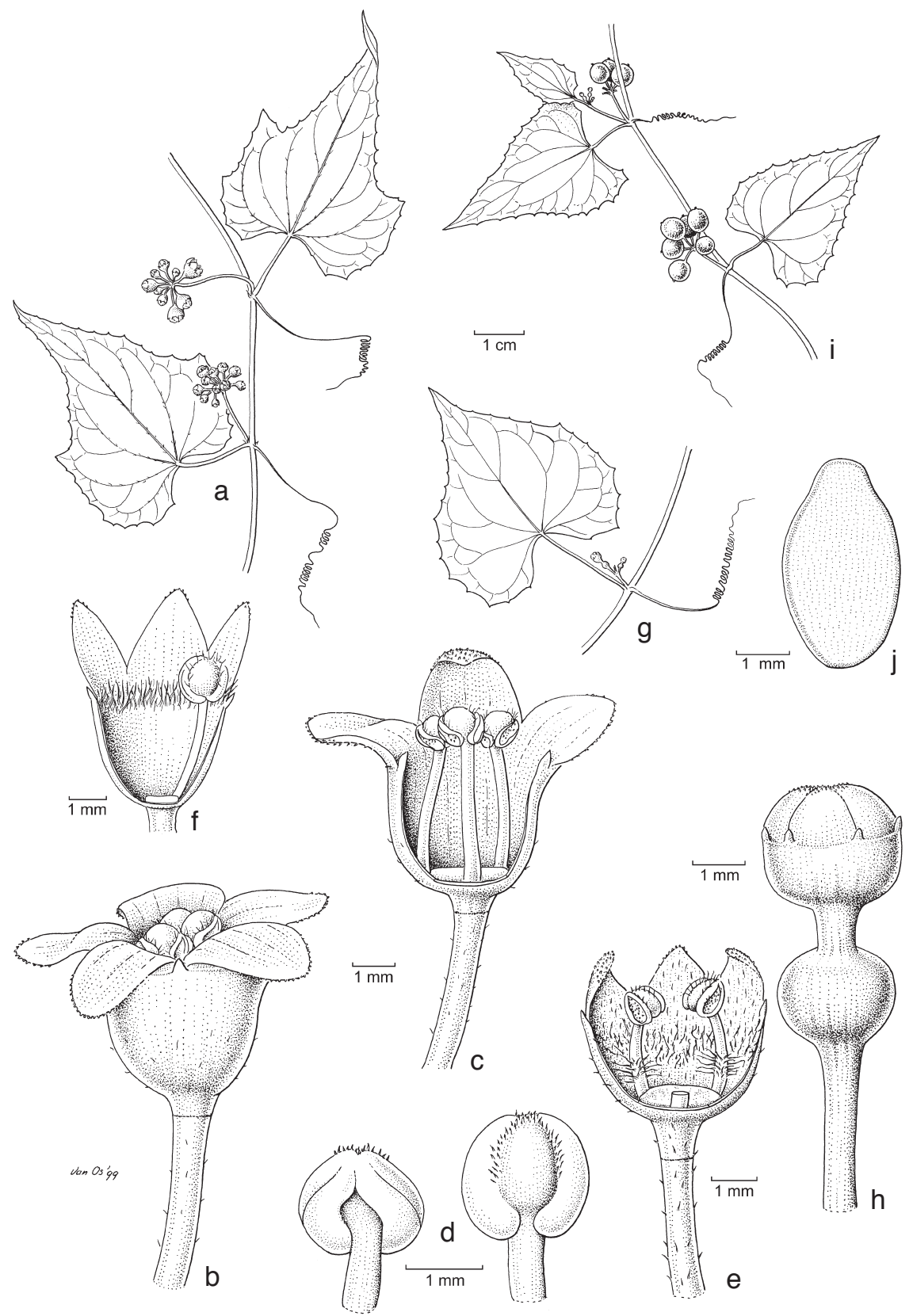

Fig. 18. Zehneria repanda (Blume) C. Simmons. a. Portion of twig with male inflorescences; b, c. male flowers; d. anthers, about as long as wide; e, f. opened male flowers of different specimens, somewhat schematic; g. node with female inflorescence; h. nearly mature female bud; i. portion of twig with infructescences; j. seed, almost destitude of marked margin (a-d: Kleinhoonte 388; e: Kleinhoonte 231; f: Anon., Herb. J.J. Smith 134; g, h: De Wilde \& Duyfjes 21764; i, j: Korthals s.n., barcode L0048302). 


\section{Zehneria repanda (Blume) C. Simmons - Fig. 18}

Zehneria repanda (Blume) C. Simmons (in Simmons \& De Wilde, 2000) 240, f. 2. - Bryonia repanda Blume (1826) 923; Ser. (1828) 305. - Melothria punctata auct. non (Thunb.) Cogn.: Cogn. (1881) 615, p.p.; (1916) 117, p.p., for the synonym Bryonia repanda Blume only. - Zehneria scabra auct. non (L.f.) Sond.: C. Jeffrey (1962) 369, p.p., for the synonym Bryonia repanda Blume only. - Lectotype (Simmons \& De Wilde, 2000): Blume s.n., barcode L0048320 (L), Java.

Zehneria exasperata Miq. (1856) 655. - Lectotype (Simmons \& De Wilde, 2000): Horsfield s.n., Acc. No. 49990A (U), Java.

Melothria cordata auct. non (Thunb.) Cogn.: Backer (1964) 297, p.p.

Zehneria maysorensis auct. non (Wight \& Arn.) Arn.: C. Jeffrey (1962) 371, p.p., for the Sumatra record only.

Climber 2-4 m; mostly dioecious; stem 1-2 mm diam.; plant glabrous or sparsely (or densely) hairy, dark on drying. Leaves: blade triangular, ovate(-elliptic), 3-8 by 2-6 cm, entire or irregularly 3(-5)-angular, with lobes to c. 1/4 deep, base truncate or broadly cordate, apex acute-acuminate, margin entire or coarsely serrate-dentate (to $5 \mathrm{~mm}$ deep, including mucro $0.5 \mathrm{~mm}$ ), upper surface scabrous with cystoliths, lower surface (almost) glabrous, but nerves subglabrous or conspicuously bristly hairy; petiole $1-3 \mathrm{~cm}$ long, glabrous or hairy. Male inflorescences: $1-2.5(-5) \mathrm{cm}$ long peduncled few- or many-flowered clusters, or flowers dispersed or \pm tiered in racemes to $1.5 \mathrm{~cm}$ long, sometimes co-axillary with a shorter second inflorescence. Male flowers: pedicels \pm patent, 2-4(-7) $\mathrm{mm}$ long; expanded perianth 4-8 mm diam.; receptacle-tube 1.5-2.5 by $2-3 \mathrm{~mm}$, (sub)glabrous but throat usually densely woolly hairy; sepals $0.5 \mathrm{~mm}$ long, patent; petals $1.5-2.5 \mathrm{~mm}$ long, outside minutely papillose-hairy; stamens inserted at the base of the receptacle-tube, filaments 1-2 mm long, glabrous or (woolly) hairy at the middle, anthers \pm globose, $1-1.5 \mathrm{~mm}$ diam., thecae half-circular, nearly horizontal, connective broad in the middle, convex, (partly) hairy; disc depressed globose, c. $1.5 \mathrm{~mm}$ diam., shallowly 3-lobed. Female flowers: in the same way disposed as male flowers but peduncle shorter, up to $1.5 \mathrm{~cm}$ long; pedicel 2-6 mm long; ovary globose, c. $1.5 \mathrm{~mm}$ diam., glabrous, neck (1-) $1.5 \mathrm{~mm}$ long; style 2-2.5 mm long, glabrous, stigma deeply 3-lobed, papillose, $1 \mathrm{~mm}$ diam.; staminodes subulate, c. $1.5 \mathrm{~mm}$ long, glabrous; disc $0.5 \mathrm{~mm}$ high, 3-lobed or 2- or 3-parted. Fruits in (short) peduncled clusters of up to 6 , sometimes with a single fruit co-axillary; globose, $0.5-0.8(-1)$ $\mathrm{cm}$ diam., glaucous-green, ultimately purplish black, glabrous; pericarp finely pitted; fruiting pedicel $0.3-0.6 \mathrm{~cm}$ long. Seeds numerous, elliptic, c. 3 by $2 \mathrm{~mm}$, not ornamented, margin absent or narrow and faint.

Field-notes - Perennial creeper; stem partly lianescent, at base c. $1 \mathrm{~cm}$ diam., covering several square metres. Flowers white fading to pale yellowish.

Distribution - Mountainous. Taiwan (1 collection, Van Steenis 20752); West and Central Malesia: Sumatra, Java, Philippines, Celebes, Lesser Sunda Islands; not known from Borneo.

Habitat \& Ecology - Scrub and forest edges; at 1400-2700 m altitude; flowering and fruiting throughout the year.

Note - Several collections tend to be intermediate with Z. mucronata, e.g. in female flowers having a relatively short neck, or margined seeds. It is possible that such specimens are hybrids or ecotypes of $Z$. mucronata which are much resembling $Z$. repanda, sharing the same harsh montane climate in the more open places. 
16. Zehneria tahitensis W.J. de Wilde \& Duyfjes, spec. nov.

Zehneria grayana simili inflorescentiae masculinae longe racemiformibus, receptaculi tubo intus (sub)glabro, fructu succido pericarpo angusto efoveolato distincta. - Typus: Vesco s.n., barcode P00218593, anno 1847, male (holo P; iso P (5 duplicates)), Tahiti.

Bryonia johnstoni Cuzent ex Seem. (1864) 48, nom. nud. (based on Pancher s.n. (P)).

Vine to $7 \mathrm{~m}$ long; dioecious; stem 2-3 mm diam.; plant glabrous, brown-green on drying. Leaves: blade ovate, 4-9 by $3.5-7 \mathrm{~cm}$, base cordate, apex (sub)acute, margin dentate-serrate, upper surface with numerous minute cystoliths; petiole $1-4 \mathrm{~cm}$ long. Male inflorescences: flowers often \pm tiered in a loose peduncled raceme, $4-10 \mathrm{~cm}$ long (peduncle 2-5 cm long). Male flowers: pedicel 3-10(-20) mm long; expanded perianth c. $7 \mathrm{~mm}$ diam.; receptacle-tube c. 2.5 by $3.5 \mathrm{~mm}$, inside glabrous; sepals c. 2 $\mathrm{mm}$ long, \pm out-curved; petals c. $3 \mathrm{~mm}$ long, very minutely glandular hairy; stamens inserted halfway the receptacle-tube, filaments $1 \mathrm{~mm}$ long, glabrous, anthers c. $1.5 \mathrm{~mm}$ diam., thecae curved, connective broad in the middle; disc depressed globose, 1.5-2 mm diameter. Female flowers: solitary, not seen. Fruit solitary, ellipsoid, $2-2.2$ by 1.4 $\mathrm{cm}$, glabrous, pale brown, bright red when fresh, juicy; pericarp thin, not pitted; fruiting pedicel c. $2 \mathrm{~cm}$ long. Seeds numerous, pear-shaped, c. 5 by $3 \mathrm{~mm}$, not ornamented, margin narrow with square edge.

Distribution - Tonga, Tahiti.

Habitat \& Ecology - In open vegetation; found at sea level to $300 \mathrm{~m}$ altitude; flowering in January and February.

Note - The flowers have been annotated on the labels as yellow or yellow-green, which is exceptional as all other Zehnerias have (creamy-)white flowers.

Specimens examined:

(All from mid-18th and 19th century and all from P): Banks \& Solander s.n., anno1769, male, Friendly Islands, Tonga; Pancher s.n., reçu 1858, fruit, Tahiti; Vesco s.n., two different collections, anno 1847 , male and fruit, Tahiti.

\section{Zehneria tenuispica W.J. de Wilde \& Duyfjes}

Zehneria tenuispica W.J. de Wilde \& Duyfjes (2004) 25. - Type: Maxwell 93-1209 (holo L), Thailand, Kanchanaburi.

Annual delicate climber 50-100 cm long; monoecious; subglabrous; green on drying. Leaves: blade subovate in outline, $3-9$ by $2.5-8 \mathrm{~cm},(3-) 5$-angular or shallowly lobed, base shallowly or deeply cordate, apex acute or (long-)acuminate, margin sparsely shallowly dentate, scabrid with minute cystoliths above; petiole $1.5-3.5 \mathrm{~cm}$ long. Male inflorescence a solitary slender peduncled spike-like raceme; peduncle 1.5-4 $\mathrm{cm}$ long, flower-bearing portion $2-4.5 \mathrm{~cm}$ long, with $5-15$ patently short-pedicelled, spaced flowers, the basal ones usually paired. Male flowers: pedicel $2.5-4 \mathrm{~mm}$ long, glabrous; perianth 2.5-3 mm diam.; receptacle tube (broad) cup-shaped, $1.5-2$ by $2-3$ $\mathrm{mm}$, glabrous except few slender hairs inside; sepals $0.2 \mathrm{~mm}$ long; petals ovate-elliptic, $0.8-1$ by $0.8-1 \mathrm{~mm}$, subobtuse, minutely papillose towards apex; stamens inserted near the base of the receptacle-tube, filaments $1.5-1.8 \mathrm{~mm}$ long, glabrous, anthers 0.3 $\mathrm{mm}$ diam., thecae vertical, somewhat curved, $0.2-0.3 \mathrm{~mm}$ long, connective slightly swollen, with few stiff hairs; disc depressed globose, 0.5 by $1 \mathrm{~mm}$. Female flowers: 
solitary on the node or co-axillary with male raceme; pedicel filiform, 12-15 mm long; ovary fusiform-ellipsoid, c. 1.5 by $1.2 \mathrm{~mm}$, glabrous, neck nearly $1 \mathrm{~mm}$ long; perianth as in male flower; style 1-1.2 mm long, stigma $0.7 \mathrm{~mm}$ diam., consisting of 3 sessile subglobose papillose free lobes; staminodes not seen; disc conspicuous, a \pm 3-lobed ring, $0.5 \mathrm{~mm}$ high, at base partly connate with receptacle. Fruit (immature) globose; fruiting pedicel at least $2.5 \mathrm{~cm}$ long. Seeds not seen.

Distribution - India (Assam), Myanmar, Thailand.

Habitat \& Ecology - Grass field in open places, rugged limestone terrain; at 400$500(-2000) \mathrm{m}$ altitude; flowering in September and October.

Specimens examined:

Clarke 9028 (Assam); Iwatsuki et al. T 10980; Maxwell 93-1209 (type) (both Thailand); Toppin s.n. (Myanmar).

18. Zehneria trullifolia W.J. de Wilde \& Duyfjes, spec. nov.

A Zehneria mucronata simili foliis trulliformibus, floribus masculinibus minute c. $4 \mathrm{~mm}$ diam. distincta. - Typus: De Vogel 5618 (holo L; iso BO, K), C Celebes.

Climber to $6 \mathrm{~m}$ long; dioecious(?); stem 1-1.5 mm diam.; plant subglabrous, (green-) brown on drying. Probract less than $1 \mathrm{~mm}$ long. Leaves: blade trullate (or narrowly ovate), $5-8$ by $3-4.5 \mathrm{~cm}$, broadest at about $1 / 4$ from the base, base broadly rounded or broadly cuneate, margin finely sparsely dentate, occasionally coarsely dentate, both surfaces glabrous, but somewhat scabrous with small cystoliths; petiole 1-3 cm long, glabrous. Male inflorescences: $1-1.5 \mathrm{~cm}$ long peduncled 3-10-flowered short racemes, 0.1-0.3 cm long. Male flowers: pedicel 1.5-2 mm long; perianth succulent, when expanded c. $4 \mathrm{~mm}$ diam., early caduceus; receptacle-tube c. 2.5 by $3 \mathrm{~mm}$, outside glabrous, inside in upper half and at throat finely woolly hairy, hairs less than $0.5 \mathrm{~mm}$ long; sepals $0.3 \mathrm{~mm}$ long, glabrous; petals c. $1.5 \mathrm{~mm}$ long, \pm acute, both surfaces minutely papillose-hairy; stamens inserted near the base in the receptacle-tube, filaments c. 1.5 mm long, glabrous, anthers subcircular, (1-) $1.5 \mathrm{~mm}$ diam., thecae curved, connective broad but narrow at apex; disc depressed, shallowly sinuate in outline, large, (0.5-)1 by c. $2 \mathrm{~mm}$. Female flowers and fruits not known.

Field-note - Flower buds greenish white.

Distribution - C Celebes, near Sopu, SSE of Palu; known only from 2 collections.

Habitat \& Ecology - In sloping primary forest with sparse undergrowth on clayey soil derived from granite; at 1000-1500 m altitude; flowering in May.

Specimens examined:

De Vogel 5310, 5618.

19. Zehneria viridifolia W.J. de Wilde \& Duyfjes, spec. nov. - Fig. 13i, j

A Zehneria erythrobacca simili in viridi i.s., folia hastata vel3-5-lobata ad medio scabra. Semina pauca plana margine late quadrata. - Typus: Brass 23914 (holo A; iso CANB,

L), Papua New Guinea, Milne Bay district.

Climber 1-2 m long; monoecious; stem 1-1.5 mm diam.; plant sparsely hairy, glabrescent, green on drying. Probract $1 \mathrm{~mm}$ long. Leaves: blade (ovate or) circular in outline, 5-9 cm diam., \pm hastate or deeply 3(-5)-lobed to c. halfway, base broadly 
shallowly cordate, margin (sparsely) dentate, upper surface short-scabrous hairy, with minute cystoliths, lower surface subglabrous but nerves hairy; petiole $1.5-3 \mathrm{~cm}$ long, rough-hairy. Male inflorescences: in peduncled short racemes, peduncle $0.5-1 \mathrm{~cm}$ long, racemes $0.1-0.5 \mathrm{~cm}$ long, up to 15-flowered. Male flowers: pedicel 4(-5) $\mathrm{mm}$ long; expanded perianth c. $5 \mathrm{~mm}$ diam.; receptacle-tube $1.5-2$ by $2.5-3 \mathrm{~mm}$, outside (sub)glabrous, in and below the throat densely woolly hairy, hairs to $0.5 \mathrm{~mm}$ long; petals 2-2.5 mm long, both surfaces minutely finely gland-hairy; stamens inserted at or slightly above halfway the receptacle-tube, filaments $0.5-1 \mathrm{~mm}$ long, glabrous, anthers \pm exserted, broad ellipsoid, c. 1.3 by $1 \mathrm{~mm}$, thecae \pm curved, connective broad, but narrow and truncate at apex; disc (depressed-) globose, c. $1.5 \mathrm{~mm}$ diameter. Female flowers: 1 or 2 at the nodes, sometimes co-axillary with male inflorescences; pedicel 5-10 mm long; ovary ellipsoid-fusiform, 3.5-4 by c. $2 \mathrm{~mm}$, glabrous, neck 1(-2) $\mathrm{mm}$ long; perianth as in male flower; style c. $2 \mathrm{~mm}$ long, with 3 style-arms $0.5 \mathrm{~mm}$ long, each with an ovoid-ellipsoid $1 \mathrm{~mm}$ long stigma, papillose; staminodes inserted at c. 1/4 from the base of the receptacle-tube, $1.5(-2) \mathrm{mm}$ long, slender, \pm hairy in the upper half; disc large, 1 by $1.8 \mathrm{~mm}$. Fruit 1 or 2; ellipsoid, 1 by $0.8 \mathrm{~cm}$, recorded as unripe (but see note); pericarp smooth, not finely pitted; fruiting pedicel $2-3 \mathrm{~cm}$ long. Seeds few, 1(-5?), ovate, c. 5 by $4 \mathrm{~mm}$, with a conspicuous broad square edge nearly $2 \mathrm{~mm}$ wide, not obviously margined.

Distribution - Papua New Guinea, Milne Bay District, Gwariu River; Biniguni Camp (Brass, 1956: pl. 17); known only from the type.

Habitat \& Ecology - Along second growth rainforest, near river; at c. $200 \mathrm{~m}$ altitude; flowering and fruiting in August.

Notes -1 . This species is tentatively treated under Zehneria, but it is not fully sure that the remarkable sole collection on which the present species is based belongs in that genus. It deviates from most Zehnerias in its green drying colour. Within Zehneria it comes closest to Z. erythrobacca (distributed all over New Guinea), the latter is distinct by a brown drying colour, by the leaf blade which is hardly lobed and not or hardly scabrous, and by the stamens which are inserted towards the base of the receptacletube.

2. The A-duplicate of Brass 23914 bears one fruit, recorded as unripe. It contains a single, apparently full-grown seed, which has no margin but a remarkably c. $2 \mathrm{~mm}$ broad square edge. Fruits of $Z$. erythrobacca are many-seeded; the seeds have a narrow margin and only a $\pm 1 \mathrm{~mm}$ broad edge. With DNA sequencing, Brass 23914 appears in the cladogram rather wide apart from both Zehneria and Neoachmandra (Cross et al., in prep.).

\section{ACKNOWLEDGEMENTS}

For this revision herbarium material of A, AAU, BCU, BK, BKF, BM, BO, BR, BRI, BRUN, CANB, CMU, E, GH, K, KEP, L, LA, LAE, MICH, MO, NSW, P, QBG, S, SAN, SING, TCD, U, UC, W, WAG, WU was consulted. We acknowledge the hospitality received in BK, BKF, BM, BO, CMU, $\mathrm{E}, \mathrm{K}, \mathrm{KEP}, \mathrm{P}, \mathrm{QBG}, \mathrm{SAN}$, SING, TCD, W and WU during herbarium visits, those to $\mathrm{W}$ and WU financed by a Synthesys-grant. Hugh Cross (Leiden) and Raymond van der Ham (Leiden), together with Kanchana Pruesapan (Leiden), did DNA analysis and pollen research, respectively. Kongkanda Chayamarit (Thailand, Bangkok, BKF) and Joan T. Pereira (Sabah, Sepilok, SAN) enabled us to do fieldwork. Jan van Os (Leiden) prepared the beautiful drawings, Fig. 11 and 17 were drawn by 
Ruth van Crevel (Leiden), Ben Kieft (Leiden) scanned the drawings and photos, Jan Frits Veldkamp (Leiden) translated the diagnoses of the new taxa into Latin, and Luc Willemse (Leiden) helped with the realisation of the identification list, using BRAHMS.

\section{REFERENCES}

Arnott, G.A.W. 1836. Pugillus plantarum Indiae Orientalis. Act. Acad. Caes. Leop. Carol. Nat. Cur. 18: 337.

Arnott, G.A.W. 1840. Remarks on the fruit of the natural order Cucurbitaceae. Madras J. Lit. Sci. 12: $48-54$.

Arnott, G.A.W. 1841. On the Cucurbitaceae. J. Bot. 3: 271-280. Longman, Orme \& Co., London.

Backer C.A. 1964. Cucurbitaceae. In: C.A. Backer \& R.C. Bakhuizen van den Brink Jr., Flora of Java 1: 292-307. Noordhoff, Groningen.

Bentham, G. 1849. In: W.J. Hooker (ed.), Niger Flora. Bailliere, London.

Bentham, G. 1866. Flora Australiensis 3: 313-322. Reeve \& Co., London.

Berhaut, J. 1975. Flore illustrée du Sénégal 3: 227-309. Gouvernement du Sénégal, Dakar.

Blanco, F.M. 1837. Flora de Filipinas. Lopez, Manila.

Blume, C.L. 1823. Catalogus van eenige der merkwaardigste zoo in- als uit-heemsche gewassen, te vinden in 's Lands Plantentuin te Buitenzorg: 105. Batavia.

Blume, C.L. 1826. Bijdragen tot de Flora van Nederlandsch Indië 15: 922-940. Ter Lands Drukkerij, Batavia.

Bole, P.V. \& M.R. Almeida. 1983. Materials for the Flora of Mahabaleshwar. J. Bombay Nat. Hist. Soc. 79, 2: 315 .

Brass, L.J. 1956. Results of the Archbold expeditions. No. 75. Summary of the fourth Archbold expedition to New Guinea (1953). Bull. Amer. Mus. Nat. Hist. 111: 83-150.

Chakravarty, H.L. 1959. Monograph on Indian Cucurbitaceae. Rec. Bot. Surv. India 17: 1-234. Calcutta.

Chakravarty, H.L. 1982. Cucurbitaceae. Fascicles of Flora of India. 11: 1-136.

Chen, S.K. 1995. Zehneria. In: C.Y. Wu, C. Chen \& S.K. Chen (eds.), Flora Yunnanica 6: 314-319. Science Press, Beijing.

Clarke, C.B. 1879. Cucurbitaceae. In: J.D. Hooker, The Flora of British India 2: 604-635. Reeve \& Co., London.

Cogniaux, C. A. 1881. Cucurbitaceae. In: A. \& C. de Candolle, Monogr. Phan. Prodr. 3: 325-951.

Cogniaux, C.A. 1908. Deux Cucurbitacées nouvelles des îles Samoa. Repert. Spec. Nov. Regni Veg. 5: 257-258.

Cogniaux, C.A. 1916. Cucurbitaceae-Fevilleae et Melothrieae. In: A. Engler, Pflanzenreich 66, iv.275.1: 1-277. Engelmann, Leipzig.

Correll, D.S. \& H.B. Correll. 1982. Flora of the Bahama Archipelago: 1429-1431. Vaduz.

Craib, W.G. 1931. Cucurbitaceae. Flora Siamensis Enumeratio. A list of the plants known from Siam 1: 750-770. Siam Society, Bangkok.

Cross, H. et al. In preparation. Molecular phylogeny of Zehneria and allies (Cucurbitaceae).

De Loureiro, J. 1790. Flora Cochinchinensis. Lisbon.

De Wilde, W.J.J.O. \& B.E.E. Duyfjes. 2004. Zehneria (Cucurbitaceae) in Thailand, with a note on the Indian Zehneria maysorensis. Thai Forest Bull., Bot. 32: 15-31.

Diggs, G.M., B.L. Lipscomb \& R.J. O’Kennon. 1999. Shinners \& Mahler's illustrated Flora of North Central Texas. Sida 16: 570-571.

Endlicher, S.L. 1833. Prodromus Florae Norfolkicae: 1-100. Vienna.

Endlicher, S.L. (1837-)1838(-1841). Iconographia Generum Plantarum. Vienna.

Fernandes, R. \& A. Fernandes. 1970. Cucurbitaceae. In: A.W. Exell, A. Fernandes \& E. J. Mendes (eds.), Conspectus Florae Angolensis 4: 232-289. Junta de investigações do Ultramar, Lisboa.

Fosberg, F.R. \& M.-H. Sachet. 1980. Systematic studies of Micronesian plants. Smithsonian Contr. Bot. 45: 15 .

Fosberg, F.R. \& M.-H. Sachet. 1981. Polynesian plant studies 6-18; 10. New combinations in Zehneria Endlicher (Cucurbitaceae). Smithsonian Contr. Bot. 47: 11-13. 
Gagnepain, F. 1921. Cucurbitacées. Flore Génerale de l'Indo-Chine 2: 1030-1095. Masson \& Cie., Paris.

Gandhi, K.N. 1976. Cucurbitaceae. In: C.J. Saldanha \& D.H. Nicolson (eds.), Flora of Hassan District, Karnataka, India: 174-181. Amerind Publishing Co. Pvt. Ltd, New Delhi.

Gray, A. 1854. United States exploring expedition during the years 1838, 1839, 1840, 1841, 1842 under the command of Charles Wilkes. Botany 1: 641-654. Philadelphia.

Haines, H.H. 1920. Some new species of plants from Behar and Orissa. J. Proc. Asiat. Soc. Bengal n. s. 15 : 309-317.

Harms, H. 1923. Über Melothria pallidinervia Zimmermann. Notizbl. Bot. Gart. Berlin-Dahlem 8, 79: $614-616$

Hayata, B. 1911. Materials for a Flora of Formosa. J. Coll. Sci., Imp. Univ. Tokyo 44: 117-122.

Hayata, B. 1921. Icones Plantarum Formosanarum 10: 5-16. Government of Formosa, Taihoku.

Hô, P.H. 1991. Cucurbitaceae. An illustrated Flora of Vietnam 1, 2: 711-728, f. 1974-2020. Mekong Printing, Santa Ana.

Hochreutiner, B.P. G. 1934. Plantae Hochreutineranae. Candollea 5: 287-290.

Hsu, Tsai-Wen, Jen-Jye Peng \& Ho-Yih Liu. 2001. Melothria pendula L. (Cucurbitaceae), a newly naturalized plant in Taiwan. Taiwania 46: 193-198.

Jacobs, M. 1954. Notes on some Malesian Cucurbitaceae. Blumea 7: 617-622.

Jeffrey, C. 1962 ('1961'). Notes on Cucurbitaceae, including a proposed new classification of the family. Kew Bull. 15: 337-371.

Jeffrey, C. 1967. Cucurbitaceae. In: E. Milne-Redhead \& R. M. Polhill (eds.), Flora of Tropical East Africa 17: 1-156. Crown Agents for Oversea Governments and Administrations.

Jeffrey, C. 1969. The genus Mukia in Asia, Malesia and Australasia. In: G. Taylor (ed.), Hooker's Icones Plantarum, serie 5, vol. 7: 1-12, t. 3661-3664.

Jeffrey, C. 1978. Cucurbitaceae. In: E. Launert (ed.), Flora Zambesiaca 4: 414-499. Flora Zambesiaca Managing Committee.

Jeffrey, C. 1979. Further notes on Cucurbitaceae IV. Some New-World taxa. Kew Bull. 33: $347-$ 380.

Jeffrey, C. 1980a. The Cucurbitaceae of Eastern Asia: 1-60. Roy. Bot. Gard., Kew.

Jeffrey, C. 1980b. Further notes on Cucurbitaceae V. The Cucurbitaceae of the Indian subcontinent. Kew Bull. 34: 789-809.

Jeffrey, C. 1990. Zehneria japonica (Cucurbitaceae), a new combination. In: D. O. Wijnands, Correct author citation for the species described on material collected by Thunberg in Japan. Thunbergia 11: 7 .

Jeffrey, C. 1995. Cucurbitaceae. In: S. Edwards, M. Tadesse \& I. Hedberg (eds.), Flora of Ethiopia and Eritrea 2, 2: 17-59. Department of Systematic Botany, Uppsala University, Sweden.

Keraudren, M. 1966. Cucurbitaceae. In: H. Humbert (ed.), Flore de Madagascar et des Comores: 1-173. Mus. Natl. Hist. Nat., Paris.

Keraudren, M. 1967. Cucurbitacées. In: J. Raynal (ed.), Flore du Cameroun 6: 5-192. Mus. Natl. Hist. Nat., Paris.

Keraudren-Aymonin, M. 1975a. Cucurbitaceae. In: P. Bamps (ed.), Flore d'Afrique Centrale (Zaïre-Rwanda-Burundi): 1-152. Jardin Bot. Natl. Belgique.

Keraudren-Aymonin, M. 1975b. Cucurbitacées. In: A. Aubréville \& J.-F. Leroy (eds.), Flore du Cambodge, du Laos et du Viêtnam 15: 1-114. Mus. Natl. Hist. Nat., Paris.

King, G. 1898. Materials for a Flora of the Malayan Peninsula. J. Asiat. Soc. Bengal, Pt. 2, Nat. Hist. 67: 24-42.

Kurz, S. 1877. Contributions towards a knowledge of the Burmese flora. J. Asiat. Soc. Bengal 46, 2: 95-106.

Léveillé, A.A.H. 1914-1915. Flore du Kouy-Tchéou. Le Mans.

Linnaeus, C. 1753. Species Plantarum 1: 35. Stockholm.

Linnaeus filius, C. 1782 ('1781’). Supplementum Plantarum Systematis Vegetabilum: 423. Braunschweig.

Liu, H.Y. 1989. Revision of Taiwan Zehneria. Bull. Natl. Mus. Nat. Sci. 1: 39-42.

Loureiro: see De Loureiro. 
Lu, A.M. \& Zhi Y. Zhang. 1986. Zehneria. In: A.M. Lu \& S.K. Chen (eds.), Fl. Reipubl. Popularis Sin. 73, 1: 169-174. Science Press, Beijing.

Makino, T. 1961. Makino's new illustrated Flora of Japan. Hokuryukan Co., Ltd, Tokyo.

Matthew, K.M. 1982. Illustrations on the Flora of the Tamilnadu Carnatic 2: pl. 291-305. Diocesan Press, Madras.

Matthew, K.M. 1983. The Flora of the Tamilnadu Carnatic 1: 633-656. Diocesan Press, Madras.

Meeuse, A.D. J. 1962. The Cucurbitaceae of Southern Africa. Bothalia 8: 1-111.

Merrill, E.D. 1909. New or noteworthy Philippine plants, VII. Philipp. J. Sci., Bot. 4: 247-330.

Merrill, E.D. 1912. Sertulum Bontocense. New or interesting plants collected in Bontoc subprovince, Luzon, by Father Morice Vanoverbergh. Philipp. J. Sci., Bot. 7: 104.

Merrill, E.D. 1914. The plants of Guam. Philipp. J. Sci., Bot. 9: 151-152.

Merrill, E.D. 1918. Species Blancoanae. Bureau of Printing, Manila.

Merrill, E.D. 1923. New or noteworthy Bornean plants. J. Malayan Branch Roy. Asiat. Soc. 1: $44-45$.

Merrill, E.D. 1926. Additions to our knowledge of the Philippine Flora, II. Philipp. J. Sci. 29: 475-496.

Merrill, E.D. 1934. New Sumatran plants. I. Pap. Michigan Acad. Sci. 19: 199-201.

Merrill, E.D. \& L.M. Perry. 1948. Notes on some Papuan collections of Mary Strong Clemens. J. Arnold Arbor. 29: 152-168.

Merrill, E.D. \& L.M. Perry. 1949. Plantae Papuanae Archboldianae, XVIII. J. Arnold Arbor. 30: $39-63$.

Miquel, F.A.G. 1856. Flora Indiae Batavae 1, 1: 652-683. Van der Post, Amsterdam.

Mueller, F.J.H. 1856. Note on the voyage of the north Australian exploring expedition, from Sydney to the mouth of the Victoria River. Hooker's J. Bot. Kew Gard. Misc. 8: 50.

Mueller, F.J.H. 1868. Fragmenta phytographiae Australiae 6. Ferres, Melbourne.

Nakai, T. 1938. On the Japanese species of Melothria. J. Jap. Bot. 14: 122-131.

Naudin, C. 1859. Revue des Cucurbitacées cultivées au muséum en 1859. Ann. Sci. Nat., Bot. sér. 4, 12: 79-164.

Naudin, C. 1862. Cucurbitacées cultivées au Muséum d'Histoire Naturelle en 1862. Ann. Sci. Nat., Bot. sér. 4, 18: 159-208.

Naudin, C. 1866. Cucurbitacées nouvelles cultivées au Muséum d'Histoire Naturelle en 1863, 1864 et 1865. Ann. Sci. Nat., Bot. sér. 5, 5: 5-43.

Ohwi, J. 1965. Flora of Japan. Smithsonian Institution, Washington, D.C.

Peekel, P.G. 1984. Flora of the Bismarck Archipelago for naturalists: 540-551. Translated by E.E. Henty. Kristen Press, Madang.

Pfeiffer, L.G.K. 1873. Nomenclator botanicus 1, 1: 60. Cassellis.

Philcox, D. 1997. Cucurbitaceae. In: M.D. Dassanayake \& W.D. Clayton (eds.), A revised handbook to the Flora of Ceylon 11: 8-46. Balkema, Rotterdam.

Prasad, V.P. \& M. Prasad. 1993. A new variety of Zehneria maysorensis (Wight \& Arn.) Arn. from Kerala, South India. J. Econ. Taxon. Bot. 17: 471-472.

Raeuschel, E. A. 1797. Nomenclator botanicus. Leipzig.

Reekmans, M. 1983. Cucurbitaceae. In: G. Troupin (ed.), Flore du Rwanda 2: 453-480. Musée Royal de l'Afrique Centrale, Tervuren.

Ridley, H.N. 1906. The botany of Christmas Island. J. Straits Branch Roy. Asiat. Soc. 45: 195.

Roemer, M. J. 1846. Peponiferarum. Syn. Monogr. 2: 1-118. Landes-Industrie-Comptoirs, Weimar. Roxburgh, W. 1832. Flora Indica 3: 701-728. Thacker \& Co., Calcutta.

Roxburgh, W. 1978. Icones Roxburghianae or drawings of Indian plants. Bot. Surv. India, Fasc. 7. Gossain \& Co., Calcutta.

Schumacher, H.C.F. 1827. Beskrivelse af Guineiske planter. Kjøbenhavn.

Schweinfurth, G. 1868. Reliquiae Kotschyanae: 44. Reimer, Berlin.

Seemann, B. 1864. The Cucurbitaceae of tropical Polynesia. J. Bot. 2: 47-52.

Seemann, B. 1865-1873. Flora Vitiensis: 103-107. Reeve \& Co., London.

Seringe, N.C. 1828. Cucurbitaceae. In: A.P. de Candolle, Prodromus systematis regni vegetabilis naturalis 3: 297-320. Treuttel \& Würtz, Paris. 
Simmons, C.M. \& W.J.J.O. de Wilde. 2000. Zehneria subgenus Zehneria (Cucurbitaceae) in Java and Bali. Blumea 45: 235-243.

Smith, A.C. 1981. Flora Vitiensis Nova 2: 673-688. Lawai, Kauai, Hawaii.

Spanoghe, J.B. 1841. Prodromus Florae Timorensis. Linnaea: 203-206.

Steudel, E.G. 1821. Nomenclator botanicus ed. 1, 1: 123. Cotta, Stuttgart \& Tübingen.

Steudel, E.G. 1841. Nomenclator botanicus ed. 2, 2: 232, 334. Cotta, Stuttgart \& Tübingen.

Stone, B.C. 1970. The Flora of Guam. A manual for the identification of the vascular plants of the Island. Micronesica 6: 561-567.

Telford, I.R. 1982. Cucurbitaceae. Flora of Australia 8: 158-198, 205.

Thunberg, C.P. 1784. Flora Japonica: 870. Leipzig.

Thwaites, G.H.K. 1859. Enumeratio plantarum Zeylaniae: an enumeration of Ceylon plants: 124-128. Dulau \& Co., London.

Van der Ham, R.W.J.M. \& K. Pruesapan. In prep. Pollen morphology of Zehneria and related genera (Cucurbitaceae). Grana.

Walker, E.H. 1971. Critical taxonomic changes concerning the plants of Okinawa and the Southern Ryukyu Islands. J. Jap. Bot. 46: 71-72.

Walker, E.H. 1976. Flora of Okinawa and the Southern Ryukyu Islands. Smithsonian Institution Press, Washington, D.C.

Wight, R. 1842. Remarks on the fruit of the natural order Cucurbitaceae. Ann. Mag. Nat. Hist., ser. 1, 8: 260-271.

Wight, R. \& G.A.W. Arnott. 1834. Prodromus Florae Peninsulae Indiae Orientalis 1: 340-351. Parbury, Allen \& Co., London.

Wunderlin, R.P. 1978. Flora of Panama. Ann. Missouri Bot. Gard. 65: 285-337.

\section{IDENTIFICATION LIST}

$$
\begin{aligned}
& \text { Indomelothria } \\
& 1=\text { I. blumei } \\
& 2 \mathrm{a}=I \text {. chlorocarpa } \\
& \text { subsp. chlorocarpa } \\
& 2 \mathrm{~b}=I \text {. chlorocarpa } \\
& \text { subsp. halimunensis } \\
& \text { Melothria } \\
& 3=\text { M. pendula } \\
& 4 \mathrm{a}=N \text {. backeri } \\
& \text { subsp. backeri } \\
& 4 \mathrm{~b}=N \text {. backeri } \\
& \text { subsp. balinensis } \\
& 5=N \text {. boholensis } \\
& 6=N \text {. brevirostris } \\
& 7=N \text {. clemensiae } \\
& 8=N \text {. cunninghamii } \\
& 9=N \text {. deltoidea } \\
& 10=N \text {. filipes } \\
& 11=N \text {. hermaphrodita } \\
& 12=N \text {. idenburgensis } \\
& 13=N \text {. indica } \\
& 14=N \text {. japonica } \\
& 15=N \text {. lancifolia } \\
& 16=N \text {. leucocarpa } \\
& 17=N . \text { macrantha }
\end{aligned}
$$

$$
\begin{aligned}
18 & =N . \text { morobensis } \\
19 & =N . \text { nesophila } \\
20 & =N \cdot \text { odorata } \\
21 & =N \cdot \text { pentaphylla } \\
22 & =N \cdot \text { platysperma } \\
23 & =N . \text { samoensis } \\
24 & =N . \text { scaberrima } \\
25 & =N . \text { sphaerosperma } \\
26 & =N . \text { wallichii }
\end{aligned}
$$$$
\text { Scopella }
$$$$
27=\text { S. diversifolia }
$$$$
28=\text { S. marginata }
$$$$
28 \mathrm{a}=\text { S. marginata }
$$
var. marginata forma affinis

$28 \mathrm{~b}=$ S. marginata var. marginata forma marginata

$28 \mathrm{c}=$ S. marginata var. penangense

Urceodiscus

$$
\begin{aligned}
29= & U . \text { arfakensis } \\
30 \mathrm{a}= & U . \text { belensis } \\
& \quad \text { var. belensis } \\
30 \mathrm{~b}= & \text { U. belensis } \\
& \text { var. conferta }
\end{aligned}
$$

$$
\begin{aligned}
30 \mathrm{c}= & U . \text { belensis } \\
& \quad \text { var. laxa } \\
31= & U . \text { carrii } \\
32= & U . \text { hippocrepicus } \\
33= & U . \text { parviflora } \\
34= & U . \text { scabridula } \\
35= & U . \text { viridis }
\end{aligned}
$$

\section{Zehneria}

$36=$ Z. baueriana

$37=$ Z. bodinieri

$38=$ Z. elbertii

$39=$ Z. erythrobacca

$40=Z$. grayana

$41=Z$. guamensis

$42=$ Z. hookeriana

$43=$ Z. immarginata

$44=Z$. maysorensis

$45=Z$. mucronata

$46=Z$. neocaledonica

$47=$ Z. pedicellata

$48=$ Z. perpusilla

$49=$ Z. pisifera

$50=$ Z. repanda

$51=$ Z. tahitensis

$52=Z$. tenuispica

$53=$ Z. trullifolia

$54=Z$. viridifolia 
Aet 53: 39 - Afriastini 574: 45 - Ajoeb 145: 28c; 413: 16 - Alston 13778: 45; 16564: 19 - Amin SAN 123557: 37 - Anderson 174: 50 - Aranay 26: 45 - Arens 77: 50 - Argent 92577: 30a - Averyanov VH 4557: 37.

Backer 2208: 13; 3491: 45; 4846: 28a; 7244: 13; 8282: 19; 12716: 16; 27258: 4a; 28153: 4a; 28293 : 4a; 28619: 4a; 28796: 4a; 29553: 4a; 29651: 4a; 31679: 13; 36583: 50; 36679: 45; 36801: 45; 36949: 16 - Bakhuizen van den Brink Sr. 436: 45; 2009: 45; 3832: 45; 4115: 50; 4553: 50; 4846: 28a; 7609: 45; 7614: 45 - Barbon PPI 1855: 5; PPI 8129: 45; PPI 12932: 45; PPI 18678: 28a - Barkmeijer 95: 45 - Bartlett 184: 28c; 467: 28a; 7228: 28a; 14681: 45 - Baskiñas 77: 45 - Baumann-Bodenheim 8604: 36; 10315: 36 - Beccari 10: 13 - Beer's collectors BSIP 7833: 40 - Bernstein 341: 28a - Bicknell 1222: 45; 1681: 45 - Bloembergen 452: 50; 3385: 45; 3386: 45 - Blume s.n. barcode L0048312: 48; s.n. barcode L0048319: 48; s.n. barcode L0048320: 50; s.n. barcode L0048324: 45; s.n. barcode L0129721: 1; s.n. barcode L0130057: 28a; s.n. barcode L0130099: 16; 267: 16; 920: 28; 920: 28b; 2034: 16 - Bodinier 1398: 13; 1957: 37 - Bois 662: 13 - Borgmann 143: 30a; 210: 30a; 256: 47; 438: 10 - Bowers 78: 30c; 297: 30c — Brass 2945: 40; 8104: 39; 10621: 34; 11046: 34; 11082: 30a; 14100: 12; 21720: 39; 23914: 54; 27609: 39; 29609: 49; 30726: 47; 30732: 47; 31994: 10 - Bristol 2438: 40 - Britton 176: 45 - Bubung 297: 45 - Bulmer 103858: 30c - Bunchuai 1282: 37 - Bünnemeyer 361: 28c; 1165: 28c; 3698: 45; 3863: 28c; 4623: 28c; 8333: 28c; 8474: 50; 11054: 45; 11090: 45; 11318 : 45; 11509: 45; 12040: 50 - Buwalda 4057: 4a; 4355: 4a - Buysman 254: 45.

Carr 11802: 39; 13190: 49; 13647: 31; 13892: 31; 13983: 49; 14850: 18; 14940: 39; 15874: 39 - Castro 1652: 28b; PPI 22140: 45 - Chai SAN 15538: 27; SAN 26920: 37 - Chang 257: 14 - Charoenchai 4633: 37 - Chen 81: 41 - Chen Nianqu 44111: 37; 44120: 14; 44723: 37 - Chew RSNH 152: 40; RSNH 193: 40 - Chow SAN 75681: 27; 78287: 14 - Christophersen 1894: 23; 2836: 40 - Chuang 2794: 37; 3274: 37; 3986: 37; 4035: 37 - Clark FB 1052: 45 - Clarke 9028: 52 - Clason-Laarman E 73: 50 - Clemens 1306: 18; 3068: 13; 3386: 37; 5144: 50; 9934: 28a; 11027: 10; 11330bis: 18; 15736: 45; 16425: 50; 17254: 50; 17505: 45; 17844 : 24; 18282: 19; 18685: 19; 18803b: 24; 18822: 13; 18854: 13; 26878: 2a; 26934: 28a; 26934A: 28a; 41287: 7 - Clunie LAE 63416: 10; LAE 63476: 30a - Coert 292: 50; 572: 45; E 59: 16 - Collins 1357: 1 - Conklin PNH 72640: 19; PNH 80579: 19; PNH 80649: 50 - Coode NGF 29921: 10; NGF 32682: 10; NGF 40364: 49 - Coveny 675: 8 - Craven 266: 40 - Croft LAE 60822: 49; LAE 60941: 30a; LAE 61893: 49 - Cuming 543: 13; 1452: 45; 1917: 13 - Cuong CP 15: 37 - Curry 1032: 40.

Damsri 34: 13 - Däniker 1174: 21; 3139: 46 - Danser 5949: 16; 5973: 50; 6288: 45 - Darbyshire 197: 45; 197A: 39 - Davis 602: 45 - De Haan 1769: 19 - De Vogel 5310: 53; 5618: 53 - De Voogd 720: 50; 1814: 43; 1826: 13; 2629: 43 - De Wilde 12614: 28c; 18234: 28c; 18998: 28c; 19094: 28c; 21657: 50; 21658: 16; 21682: 45; 21699: 28a; 21704: 4b; 21705: 4b; 21708: 50; 21727: 45; 21728: 45; 21732: 4b; 21747: 45; 21748: 45; 21751: 28a; 21754: 28a; 21756: 28a; 21764: 50; 21765: 50; 21776: 45; 21794: 28c; 21800b: 28c; 21816: 45; 21843: 16; 21857: 48; 21866: 16; 21875: 2b; 21876: 2b; 21877: 2b; 21878: 2b; 21879: 2b; 21893: 45; 21894: 13; 21914A: 48; 21927: 2b; 21928: 2b; 21935: 19; 21936: 19; 21946: 16; 21968: 37; 21972: 28c; 22057: 2a; 22147: 37; 22149: 26; 22153: 26; 22154: 28a; 22157: 26; 22165: 37; 22168: 26; 22171: 37; 22176: 28c; 22177: 26; 22182: 28b; 22271: 2b; 22272: 45; 22281: 16; 22285: 16; 22289: 11; 22290: 28c; 22303: 25; SAN 139454: 3; SAN 141903: 28b; SAN 141904: 28b; SAN 141909: 2a; SAN 141911: 2a; SAN 141933: 37; SAN 143748: 27; SAN 143915: 2a; SAN 143942: 2a; SAN 143948: 2a; SAN 144013: 2a; SAN 144014: 28b - Den Hoed \& Kostermans 680: 6 - Deng Liang 7233: 14; 7607: 14; 7904: 14; 8523: 14; 9638: 14 - Dennis BSIP 4449: 40 - Dietrich 347: 8 - Docters van Leeuwen 1469: 4a; 1576: 4a - Docters van Leeuwen-Reynvaan 252: 16; 1334: 45; 1698: 48; 2373: 50; 2374: 50 - Dorgelo 463: 50; S 342: 50 - Dosedla 237: 30c.

Edaño BS 16069: 45; BS 18768: 24; BS 46171: 28a; PNH 954: 45; PNH 1072: 45; PNH 11421: 45 — Edeling 19782: 1 - Elbert 557: 13; 1363: 43; 1637: 38; 1757: 45; 2291: 43; 4158: 19; 4203: 45; 4326: 19; 4470: 45; 4577: 45 - Elmer 5862: 24; 8428: 50; 9922: 45; 15448: 45; 15531 : 45; 20582: 37 - Endert 2080: 1 - Ernst 481: 45 - Excursion Burangrang 3027: 50 - Eyma 1442: 50 . 
Fan 3: 14 - Fénix BS 12758: 24 - Flenley ANU 2185: 49; ANU 2628: 49 - Floyd NGF 7485: 10 - Forbes 3457: 19; 3627: 45; 3919: 19; 3957: 19 - Foreman LAE 60179: 49 - Fosberg 43433: 41; 57963: 37 - Fox PNH 9223: 45 - Frake PNH 36126: 28a - Frodin NGF 26539: 40; UPNG 5459: 49 - Fuentes PPI 38908: 45 - Fujimoto 512: 14.

Gadoh anak Umbai KL 1834: 28c - Gaerlan PPI 2803: 45; PPI 3290: 45; PPI 4791: 3; PPI 4953: 45; PPI 5234: 45; PPI 10915: 45; PPI 23101: 19; PPI 26598: 50 - Garcia PPI 15893: 50; PPI 25161: 45; PPI 25179: 45; PPI 25271: 45 - Gardner 7027: 10; 7270: 30c; 9646: 49 - Garrett 360: 37; 1082: $28 \mathrm{c}$ - Gaudichaud 13: 19 - Gideon LAE 77156: 40 - Gilli 88: 10 - Govindarajalu 8780: 42 - Gravendeel 542: 2b - Green RSNH 1281: 40 - Griffith SJG 2/27: 40 - Grutteringk 3039: 45 - Guam Experiment Station 11: 41 - Guillaumin 8611: 21; 8895: 46; 9496: 21; 10046: 23; 10500: 23.

Haines 4510: 20 - Hallier 384: 50; 1374: 1 - Haniff SF 14994: 28a - Hansen 12910: 37 - Harreveld 2651: 50 - Hatusima 17634: 41; 21661: 41 - Henty NGF 29145: 45 - Herb. Alleizette 2638: 14 - Herb. Boerlage 144: 13; 146: 13; 153: 45 - Herb. Reinwardt 1378: 19 - Herb. Waitz 68: 45 - Hernaez 3532: 50 - Hochreutiner 1316: 16 - Höft 2599: 10 - Hohenacker 1115: 42 - Hoogerwerf 162a: 13 - Hoogland 5402: 10; 5926: 49; 6737: 49; 6798: 30c; 7351: 49; 7537: 30b; 10468: 39 - Hosakawa 5794: 41 - Hou Kuanzhao 70509: 14 - Huang 10507: 41 - Huang Cheng 160345: 14; 161694: 14; 162397: 14 - Huang Maoxian 111100: 14; 113048: 14.

Iboet 250: 45; 541: 45 - Isles NGF 32464: 39 — Iwatsuki P 1036: 45; S 1732: 28a; T 10339: 26; T 10980: 52.

Jaag 466: 4a - Jacobs 4471: 50; 4547: 28c; 4983: 45; 7043: 50; 7368: 50 - Jaheri 967: 2a - Johns 9208: 34 - Joseph B. SAN 116982: 27; SAN 123681: 27; SAN 123805: 27 - Junghuhn s.n. barcode U0001468: 16.

K'tung 78 6341: 14 - Kairo NGF 30905: 18 - Kajewski 1631: 40 - Karsten 33: 50 - Katik LAE 56391: 31; NGF 46781: 39 - Keng 720: 14 - Kerenga LAE 56617: 30a - Kern 8495: 45; 8644: 45 - Kerr 1942: 26; 3735: 1; 4313: 13; 4619: 26; 19842: 6 - Khantchai 1113: 28 - Kiapranis LAE 69127: 30a - King's collector 874: 28b - Kleinhoonte 118: 50; 231: 50; 388: 50; 648: 28c - Kock 11: 50; 12: 16 - Köie 1504: 40 - Kondo PNH 38995: 45 - Koonkhunthod 330: 11; 333: 37 - Koorders 16589: 19; 22053: 28a; 22763: 45; 23117: 45; 23193: 45; 26045: 50; 26064: 16; 29194: 45; 29197: 45; 29982: 45; 30240: 45; 37374: 50; 40496: 1 ; 40593: 1 ; 43255: 50; 43256: 45; 43476: 50; 43643: 50; 43816: 50 - Kooy 66: 45; 663: 45; 725: 45; 1363: 45; 1392: 45 - Kornassi 692: 45; 1519: 45 - Korthals 5a: 16; 128: 1; 137: 13; 826: 45 - Koster BW 13866: 45 - Kostermans 655: 32; 733: 43; 1096: 6; 18399: 48; 18823: 45; 23050: 9; 25093: 9 - Koyama T 31187: 6; T 61152: 26; T 61506: 37; T 61607: 37 - Kramer 7639: 37 - Krispinus SAN 95664: 27 - Kuhl 140: 16 - Kuhl \& Van Hasselt s.n. barcode L0130076: 16; - Kuntze 4674: 50 - Kurz 1889: 1.

Lam 118: 50 - Larsen 1193: 6; 2249: 26; 31538: 28a; 43664: 26; 45353: 6; 46847: 37; 46849: 37 - Lau 435: 37; 28628: 37 - Lelean LAE 52550: 39 - Leu 2171: 41 - Liang Xiangri 66252: 37 - Liu Xinqi 24040: 37; 24259: 37; 25326: 14; 25491: 14; 28058: 14 - Liu Yingguang 2210: 14; 2240: 14; 2802: 37 - Loeters 1562: 19; 1563: 19; 1580: 43; 1741: 43 - Loher 2136: 24; 5109: 13; BS 13097: 24; BS 13742: 45 - Lomudin Tadong 273: 27 - Lörzing 1112: 28c; 3385: 1; 4707: 28c; 5721: 28c; 5888: 28c; 5952: 28c; 6048: 50; 6794: 50; 6957: 28c; 8066: 28a; 11291: 37; 14141: 28c; 15162: 28c - Lorence Lugas 1915: 28b - Lütjeharms 3756: 45; 4834: 28c; 5323: 28c; 5328: $28 \mathrm{c}$.

Madani SAN 111189: 37 - Madulid PPI 9686: 50; PPI 11592: 37 - Maingay 1268: 28b - Mangen 2395: 34 - Mann NGF 43163: 39 - Marcan 454: 13; 2346: 26 - Martelino BS 35697: 45 - Matthew RHT 25792: 42 - Mauriasi BSIP 12093: 40 - Maxwell 74-618: 26; 86-493: 28b; 86-1050: 28; 87-919: 26; 87-1115: 37; 87-1116: 28c; 88-844: 26; 88-959: 37; 89-1238: 37; 90-799: 26; 90-824: 26; 90-936: 28c; 90-1104: 37; 92-35: 37; 92-486: 37; 92-605: 37; 93-1140: 28; 93-1146: 28a; 93-1209: 52; 93-1283: 28b; 95-539: 26; 95-1189: 37; 95-1195: 37; 96-1151: 26; 97-410: 28a; 97-554: 37; 97-1254: 28c; 97-1280: 37; 98-1076: 37; 01-640: 37; 02-436: 37 - McClure 9825: 14; BS 15927: 50; BS 15937: 24 - McGregor BS 12417: 45; BS 43687: 45; BS 43849: 45; BS 47370: 45 - McKee 3504: 21 - Mearns BS 4287: 50 - Meebold 9738: 37 — Meer-Mohr 59:28c - Meijer 59: 50; 1893: 9; 2913: 16; 5311: 28c; 6680: 16 - Mendoza PNH 
18150: 45; PNH 18247: 45 - Merrill 3086: 45; 14421: 13; BS 4657: 24; BS 4792: 50 - Middleton 982: 28c; 1249: 11; 1477: 28c; 1527: 28c - Millar NGF 35205: 10 - Millard KL 953: 28c; KL 1762: 28c - Milliken 1315: 39 - Mitchell M 21: 45 - Mitsuta T 38223: 25 - Mogea 2534: 45 - Mondi 95: 28a - Monod de Froideville 1773: 13 - Moran 5122: 41 - Morrison 302: 40 - Motley 386: 13; 881: 28b - Mousset 648: 19 - Mundo 66: 45 - Murata J 1349: 45; T 51486: $28 \mathrm{a}$.

Nagamasu 3760: 28c - Nakano 1: 16; 46: 16 - Nakisi BSIP 8209: 40 - Nedi 231: 45 - Neubauer 252: $28 \mathrm{a}$ - Newman 1032: 28c; 1152: 6 - Niyomdham 3320: 28 - Noguchi 3577: 41 - Nooteboom 733: 28c; 5132: 45; 5194: 45.

Odashima 17743: 37; 17744: 37 - Ohwi 115: 14.

Paie S 47297: 13 - Paijmans 1107: 15 - Palee 314: 26; 428: 26 - Pereira JTP 710: 2a; SAN 151222: 2a - Perrottet 253: 37 - Pételot 3164: 37 - Petrmitr 90: 26; 364: 37 — Phengklai 675: 37; 6849: 28c - Phengnaren 676: 37 - Phonsena 3911: 28; 3912: 37; 3937: 28; 3995: 37; 4015: 22; 4409: 11; 4411: 28c; 4412: 37; 4420: 37; 4421: 37; 4424: 11; 4425: 37; 4439: 37; 4457: 28b; 4460: 26; 4468: 37; 4474: 26; 4638: 11; 4652: 11 - Poilane 27102: 37 - Polak 679: 13 — Pooma 2990: 25; 3038: 37; 3043: 25 - Popta 181: 45; 809 234: 16 - Postar SAN 139454: 3; SAN 141901: 3; SAN 143729: 2a; SAN 144096: 2a - Posthumus 941: 28a; 1046a: 1; 3055 : 45 - Powell BSIP 19393: 40 - Pratt TKP-NG 88: 10 - Pulle 2627: 16; 3095: 50; 4047: 50; 4067: 16 - Pullen 427: 49; 5364: 30a - Put 1821: 6.

Raap 140: 28c; 650: 50 - Rahmat si Boeea 9475: 28c - Ramlanto 968: 45 - Ramos 394: 45; 1210: 27; 1896: 27; 2023: 45; BS 5564: 50; BS 12204: 19; BS 14608: 24; BS 28713: 45; BS 31134: 45; BS 31140: 28; BS 37215: 5; BS 40215: 17; BS 42732: 45; BS 42779: 5; BS 44212: 5; BS 44466: 19; BS 45054: 24; BS 48236: 45; BS 48429: 24; BS 49441: 45 - Rao 10848: 37 - Rappard 140K: 28c; 161: 28c - Rau 136: 30a - Raynal RSNH 16307: 40 - Rechinger 660: 23; 1035: 23; 1597: 40; 1601: 23; 1629: 23; 5244: 23 - Reeve 4566: 49 - Reinecke 64: 23; 398: 23 - Reinwardt 90: 16; 142: 16; 1767: 50 - Rensch 1175: 48; 1496: 48 - Reynoso PPI 1022: 45; PPI 1210: 45; PPI 3511: 50; PPI 3555: 45; PPI 7805: 5; PPI 14004: 45; PPI 14956: 45; PPI 24835: 45; PPI 27019: 45 — Ridsdale 206: 37; NGF 30187: 49 — Rivera BS 75014: 45 - Robinson 394: 19; 1870: 45 - Roeloffs 41: 28a.

Saito 7354: 37; 7410: 37; 7566: 37 - Sanan 471: 28c — Sands 6809: 29; 7143: 34; $7328: 45$ - Santos BS 31662: 50; BS 32011: 24 - Sarip 31: 45 - Sastry 40599: 20 - Saulière 33: 42 - Savateur 95: 28 - Savinierre 97: 19 - Sayers NGF 19800: 10; NGF 19833: 31; NGF 19891: 30a - Schmutz 160: 19; 1409: 45; 2471: 43; 2912: 13 - Schodde 1385: 49; 2546: 45; 2561: 18 ; 4943: 30b - Schram BW 9477: 39; BW 14984: 45 - Scortechini 495: 28a - Sebastine 4014: 42; 4874: 42 - Setchell 290: 23 - Shen 519: 41 - Shimizu T 7749: 26; T 10570: 37; T 10792: 26; T 11660: 37; T 18705: 37 - Sijde BW 4066: 39 - Sinclair 9652: 45 - Sino-American Botanical Expedition 1984 1270: 37 - Sino-American Guizhou Botanical Expedition 1986 77: 37 - Smitinand 1339: 25; 4086: 28c - Soejarto 11719: 13 - Soejatmi 10: 19 - Soewarta 4: 50 - Somran 2285: 26; 2307: 28a; 2391: 13; 2519: 37 - Songkhla 258: 13 - Sørensson 596: 28; 3906: 26; 6091: 37 - Species Blancoanae 848: 13 - Squires 14: 13 - Steiner 79: 50; 264: 50; 1495: 50; 2023: 50; PNH 35897: 50 - Sterly 80 471: 47 - Stevens LAE 50312: 49; LAE 51119: 30c; LAE 55707: 31 - Steward 549: 14 - Stone 4700: 41; 14311: 28c; PPI 206: 28b; PPI 642: 45; PPI 672: 45 - Street 242: 10 - Streimann LAE 51704: 39; NGF 25855: 10; NGF 26027: 10; NGF 39472: 45; NGF 47787: 10 - Subramanian 61: 42; 570 : 42 - Sulit PNH 17162: 19 - Surbeck 129: 50 - Sykes 503: 23.

Tagawa T 9304: 28c; T 9793: 26; T 10619: 26 - Takeuchi 10518: 49; 11813: 39; 12105: 10; 12915 : 31; 12990: 10; 13954: 39; 16328: 18 - Tan Peixiang 57147: 37; 57148: 14; 59340: 14; 60119: 14 — Thwaites CP 1610: 9; CP 1613: 37; CP 2581: 9; CP 3128: 9 - Ting 1136: 14 - Tracey 25756: 8 - Tsang 14337: 14; 15024: 37; 16453: 37 - Tsi Zhanhuo 91 400: 37 - Turnau 793: $28 \mathrm{c}$.

University of San Carlos 900: 5 - Uong Sing Po 12588: 14 - Utami 7: 19.

Van Balgooy 7370: 16; 7544: 3 - Van Beusekom 1373: 9; 2660: 37; 3983: 6; 4468: 37 - Van Royen 6002: 33; NGF 14623: 49; NGF 20285: 49 - Van Steenis 3742: 28c; 5264: 45; 6067: 28c; 8029: 4b; 9387: 28a; 9431: 28c; 10542: 13; 11903: 19; 18350: 45; 18578: 45; 20752: 50 — Vanoverbergh 184: 45 - Vavangot 4317: 9 - Veldkamp 5501: 30c; 7061: 45; 7081: 19 — Vergara 57: 45 - Verheijen 25: 19; 263: 19; 264: 19; 641: 48; 643: 48; 736: 19; 737: 19; 3358a: 43; 3358b: 
43; 3430: 45; 3543: 19; 3806: 48; 5463: 45 - Vesco s.n. barcode P00218593: 51 - Vinas UPNG 4874: 47 - Vink BW 11483: 39; BW 15396: 35; 16344: 9.

D. Walker ANU 722: 49; ANU 819: 30a - G.W. Walker 273: 9 - Walker-Paton 16: 9 - Walsh 45: 45 - Wang Xuewen 28: 14; 8206: 14 - Waterhouse 177B: 40 - Wawra 1089: 9 - Wei Zhaofen 120817: 14 - Weiblen 1020: 30a - Weinland 109: 39 - Wheeler ANU 5839: 10 - Whitmore BSIP 5903: 40 - Wiakabu LAE 73490: 39 - Widjaja EA 6961: 39 - Wieringa 3423: 50 - Wight 1116: 44; 1117: 42; 1149: 44; 1150: 42; 1151: 37 - Williams 1055: 24; 1364: 28b - Winckel 1246b: 45 - Wirawan 482: 45 - Wiriadinata 15: 45; 405: 45; 8145: 2b - Womersley 4906: 49; 5343: 30a; 5364: 49; NGF 8486: 49; NGF 13993: 30a - Wood 2020: 27 - Wright 87: 41 - Wuyi Shan 80 671: 14.

Xinh MVX 439: 13.

Yamazaki 5922: 41; 6639: 14 - Yang 1577: 41 - K. Yao 8184: 14 - Yates 1249: 28a; 1566: 45; 2878: 50 - Ye Huagu 1098: 14 - Yu TAI 204: 37 - Yuncker 15877: 23.

Zhang Zhaoqian 11483: 14; 12082: 14 - Zhong Shuquan 1326: 14 - Zippelius 1564: 13 - Zollinger 1127: 45; 1739: 46.

\section{INDEX}

Accepted names are in roman type, new species and combinations in bold and synonyms in italics. The numbers behind the species names are the combination of genus number - species number.

Achmandra Arn. [p. 12]

Aechmandra blumeana M. Roem. 4-2a

deltoidea Arn. 3-6

indica (Lour.) Arn. 3-10

Bryonia arguta Span. 6-10

blumei Ser. 1-1

cissoides Wallich Cat. 6698 6-2

deltoidea Arn. 3-6

epigaea auct. 4-2a

filicaulis Wall. 4-2b

filiformis Roxb. 2-1

geminata Blume 3-10

heterophylla Blume 1-1

heterophylla auct. 4-2b

hookeriana Wight \& Arn. 6-7

japonica Thunb. 3-11

johnstoni Cuzent ex Seem. 6-16

leucocarpa Blume 3-13

marginata Blume 4-2, 4-2a

maysorensis Wight \& Arn. 6-9

mucronata Blume 6-10

oxyphylla Wallich Cat. 6697 6-2

perpusilla (Blume) Blume 6-13

repanda Blume 6-15

scabrata Blume 6-13

stipulacea Willd. $\beta$ perpusilla (Blume) Ser. 6-13

tenella Roxb. 3-10

Bryonopsis leucocarpa (Blume) Miq. 3-13

Cerasiocarpum maingayi C.B. Clarke 4-2a penangense C.B. Clarke 4-2b

Cucumis luzonicus Blanco 3-10

Cucurbita perpusilla Blume 6-13 scabra Blume 6-13
Diplocyclos palmatus auct. 6-4

Indomelothria W.J. de Wilde \& Duyfjes [p. 5]

blumei (Ser.) W.J. de Wilde \& Duyfjes 1-1

chlorocarpa W.J. de Wilde \& Duyfjes 1-2

subsp. chlorocarpa 1-2a

subsp. halimunensis W.J. de Wilde \& Duyfjes 1-2b

Karivia samoensis A. Gray 6-5 var. vitiensis A. Gray 6-5

Melothria L. [p. 9]

affinis King 4-2a

alba (Ridl.) Cogn. 6-10

baueriana F. Muell. 6-1

belensis Merr. \& L.M. Perry 5-2

bodinieri $\mathrm{H}$. Lév. 6-2

boholenses Merr. 3-2

carnosula Cogn. 6-5

cissybium M. Jacobs 5-2, 6-14

clemensiae Merr. \& L.M. Perry 3-4

cordata auct. 6-15

cunninghamii (F. Muell.) Benth. 3-5

deltoidea (Arn.) Thwaites 3-6

diversifolia Merr. 4-1

filipes Merr. \& L.M. Perry 3-7

formosana Hayata 3-11

gracilipes Merr. 4-2a

grayana Cogn. 6-5

guamensis Merr. 6-6

idenburgensis Merr. \& L.M. Perry 3-9

indica Lour. 3-10

indica auct. 6-4

japonica (Thunb.) Cogn. 3-11 
(Melothria)

leucocarpa (Blume) Cogn. 3-13

var. triloba (C.B. Clarke) Chakrav. 3-17

leucocarpa auct. 3-17

liukiuensis Nakai 6-6

lobata Merr. 6-10

marginata (Blume) Cogn. 4-2a

var. $\beta$ heterophylla (Blume) Cogn. 1-1

morobensis Merr. \& L.M. Perry 3-15

mucronata (Blume) Cogn. 6-10

odorata C.B. Clarke 3-17

var. triloba C.B. Clarke 3-17

pendula L. 2-1

pentaphylla Naudin 3-18

perpusilla (Blume) Cogn. 6-13

var. subtruncata Cogn. 6-2

perpusilla auct. 6-2

punctata auct. 6-15

rauwenhoffii Cogn. 3-13

var. pengalenganensis Hochr. 3-13

rechingeri Cogn. 3-20

regelii Naudin 3-11

samoensis A. Gray 3-20

scaberrima Merr. 3-21

scabridula Merr. \& L.M. Perry 5-6

thwaitesii Schweinf. 3-6

wallichii C.B. Clarke 3-23

zehnerioides Haines 3-17

zeylanica C.B. Clarke 3-6

Neoachmandra W.J. de Wilde \& Duyfjes [p. 12]

backeri W.J. de Wilde \& Duyfjes 3-1

subsp. backeri 3-1a

subsp. balinensis W.J. de Wilde \& Duyfjes $3-1 b$

boholensis (Merr.) W.J. de Wilde \& Duyfjes 3-2

brevirostris (W.J. de Wilde \& Duyfjes)

W.J. de Wilde \& Duyfjes 3-3

clemensiae (Merr. \& L.M. Perry)

W.J. de Wilde \& Duyfjes 3-4

cunninghamii (F. Muell.) W.J. de Wilde \& Duyfjes 3-5

deltoidea (Arn.) W.J. de Wilde \& Duyfjes 3-6

filipes (Merr. \& L.M. Perry) W.J. de Wilde \& Duyfjes 3-7

hermaphrodita (W.J. de Wilde \& Duyfjes)

W.J. de Wilde \& Duyfjes 3-8

idenburgensis (Merr. \& L.M. Perry)

W.J. de Wilde \& Duyfjes 3-9

indica (Lour.) W.J. de Wilde \& Duyfjes 3-10
(Neoachmandra)

japonica (Thunb.) W.J. de Wilde \& Duyfjes 3-11

lancifolia W.J. de Wilde \& Duyfjes 3-12

leucocarpa (Blume) W.J. de Wilde \& Duyfjes 3-13

macrantha W.J. de Wilde \& Duyfjes 3-14

morobensis (Merr. \& L.M. Perry)

W.J. de Wilde \& Duyfjes 3-15

nesophila W.J. de Wilde \& Duyfjes 3-16

odorata (C.B. Clarke) W.J. de Wilde \&

Duyfjes 3-17

pentaphylla (Naudin) W.J. de Wilde \&

Duyfjes 3-18

platysperma W.J. de Wilde \& Duyfjes 3-19

samoensis (A. Gray) W.J. de Wilde \& Duyfjes 3-20

scaberrima (Merr.) W.J. de Wilde \& Duyfjes 3-21

sphaerosperma (W.J. de Wilde \& Duyfjes)

W.J. de Wilde \& Duyfjes 3-22

wallichii (C.B. Clarke) W.J. de Wilde \&

Duyfjes 3-23

Pilogyne baueriana (Endl.) Steud. 6-1

Rhynchocarpa deltoidea Kurz 1-1

Scopella W.J. de Wilde \& Duyfjes [p. 34]

diversifolia (Merr.) W.J. de Wilde \& Duyfjes 4-1

marginata (Blume) W.J. de Wilde \& Duyfjes 4-2

var. marginata $4-2 \mathrm{a}$

informal form 'affinis' [p. 38]

informal form 'marginata' [p. 38]

var. penangense (C.B. Clarke)

W.J. de Wilde \& Duyfjes 4-2b

Urceodiscus W.J. de Wilde \& Duyfjes [p. 38]

arfakensis W.J. de Wilde \& Duyfjes 5-1

belensis (Merr. \& L.M. Perry) W.J. de Wilde \& Duyfjes 5-2

var. belensis $5-2 \mathrm{a}$

var. conferta W.J. de Wilde \& Duyfjes $5-2 b$

var. laxa W.J. de Wilde \& Duyfjes 5-2c

carrii W.J. de Wilde \& Duyfjes 5-3

hippocrepicus W.J. de Wilde \& Duyfjes 5-4

parviflora W.J. de Wilde \& Duyfjes 5-5

scabridula (Merr. \& L.M. Perry)

W.J. de Wilde \& Duyfjes 5-6

viridis W.J. de Wilde \& Duyfjes 5-7

Zehneria Endl. [p. 48]

subg. Pseudokedrostis C. Jeffrey [p. 12]

alba Ridl. 6-10 
(Zehneria)

baueriana Endl. 6-1

bodinieri (H. Lév.) W.J. de Wilde \& Duyfjes 6-2

brevirostris W.J. de Wilde \& Duyfjes 3-3

cunninghamii F. Muell. 3-5

deltoidea Miq. 3-13

$\beta$ subintegerrima Miq. 3-13

elbertii W.J. de Wilde \& Duyfjes 6-3

erythrobacca W.J. de Wilde \& Duyfjes 6-4 exasperata Miq. 6-15

grayana (Cogn.) Fosberg \& Sachet 6-5

var. vitiensis (A. Gray) Fosberg \& Sachet 6-5

guamensis (Merr.) Fosberg 6-6

hermaphrodita W.J. de Wilde \& Duyfjes 3-8

hookeriana (Wight \& Arn.) Arn. 6-7

hookeriana auct. 6-2

immarginata W.J. de Wilde \& Duyfjes 6-8

indica (Lour.) Keraudren 3-10

japonica (Thunb.) H.Y. Liu 3-11

japonica auct. 3-10

kelungensis Hayata 6-6

liukiuensis (Nakai) E. Walker 6-6

marginata (Blume) Keraudren 4-2a
(Zehneria)

maysorensis (Wight \& Arn.) Arn. 6-9 var. oblonga V.P. Prasad \& M. Prasad 6-9

maysorensis auct. 6-2, 6-15

mucronata (Blume) Miq. 6-10

mucronata auct. 6-5

neocaledonica W.J. de Wilde \& Duyfjes 6-11

pedicellata W.J. de Wilde \& Duyfjes 6-12 perpusilla (Blume) Bole \& M.R. Ameida 6-13

pisifera W.J. de Wilde \& Duyfjes 6-14 repanda (Blume) C. Simmons 6-15

samoensis (A. Gray) Fosberg \& Sachet 3-20

scabra auct. 6-7, 6-13, 6-15

sphaerosperma W.J. de Wilde \& Duyfjes 3-22

tahitensis W.J. de Wilde \& Duyfjes 6-16 tenuispica W.J. de Wilde \& Duyfjes 6-17 thwaitesii (Schweinf.) C. Jeffrey 3-6 trullifolia W.J. de Wilde \& Duyfjes 6-18 viridifolia W.J. de Wilde \& Duyfjes 6-19 wallichii (C.B. Clarke) C. Jeffrey 3-23 